NBSIR 85-3282

\title{
Survey of Alternate Stored Chemical Energy Reactions
}

L. P. Cook

E. R. Plante

U.S. DEPARTMENT OF COMMERCE

National Bureau of Standards

Institute for Materials Science and Engineering

Ceramics Division

Gaithersburg, MD 20899

December 1985

Prepared for:

Department of the Navy

fice of Naval Research

$-Q C$ l lington, VA 22217

100

.456

$85-3282$

1985 

L. P. Cook

E. R. Plante

U.S. DEPARTMENT OF COMMERCE

National Bureau of Standards

Institute for Materials Science and Engineering

Ceramics Division

Gaithersburg, MD 20899

December 1985

Prepared for:

Department of the Navy Office of Naval Research

Arlington, VA 22217

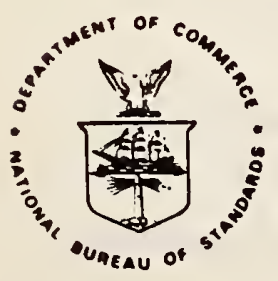

U.S. DEPARTMENT OF COMMERCE, Malcolm Baldrige, Secretary NATIONAL BUREAU Of STANDARDS, Ernest Ambler, Director 



\section{Survey of Alternate Stored Chemical Energy Reactions}

Annual Report

For the Period May 25, 1984 May 25, 1985

L. P. Cook and E. R. Plante

Inorganic Materials Division

Institute for Materials Science and Engineering

National Bureau of Standards

Gaithersburg, MD 20899

September 15, 1985

Prepared for the Department of the Navy

Office of Naval Research

Arlington, VA 22217

APPROVED FOR PUBLIC RELEASE: DISTRIBUTION UNLIMITED

Under Contract Nos. N00014-83-F-0117 and N0014-84-F-0204

REPRODUCTION IN WHOLE OR IN PART IS PERMITTED FOR ANY PURPOSE OF THE

U. S. GOVERNMENT 
Table of Contents

Abstract . . . . . . . . . . . . . . . . . . . . . 5

I. Introduction . . . . . . . . . . . . . . . . . . 6

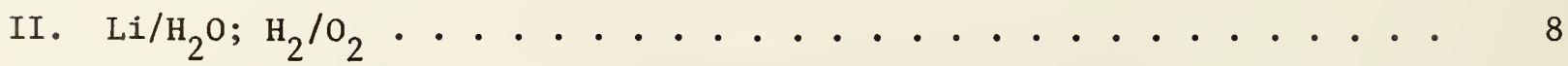

A. Starting Materials and Container Materials . . . . . . . 8

B. Reaction Products . . . . . . . . . . . . . . 9

c. Kinetics . . . . . . . . . . . . . . . . . 9

D. Enthalpy . . . . . . . . . . . . . . . . . 10

E. Safety Considerations . . . . . . . . . . . . . 11

III. $\mathrm{Li} / \mathrm{H}_{2} \mathrm{O} ; \mathrm{NaO}_{2} / \mathrm{H}_{2} \mathrm{O} ; \mathrm{H}_{2} / \mathrm{O}_{2}$. . . . . . . . . . . . . . . . . 11

A. Starting Materials . . . . . . . . . . . . . . 11

B. Reaction Products . . . . . . . . . . . . . . 12

c. Kinetics . . . . . . . . . . . . . . . 12

D. Enthalpy . . . . . . . . . . . . . . . . . . 13

E. Safety Considerations . . . . . . . . . . . . . . 14

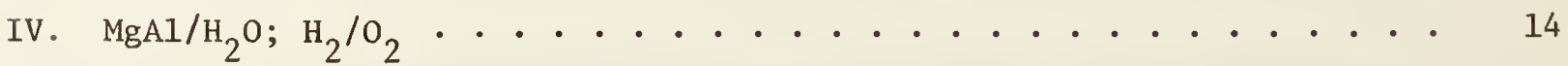

A. Starting Materials . . . . . . . . . . . . . 14

B. Reaction Products ................. . 15

C. Kinetics . . . . . . . . . . . . . . . 15

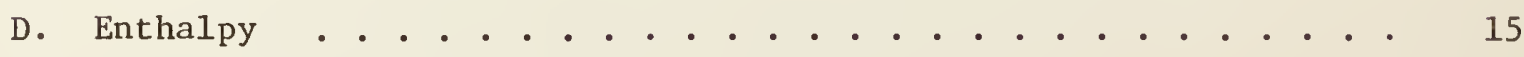

E. Safety Considerations . . . . . . . . . . . . 16 


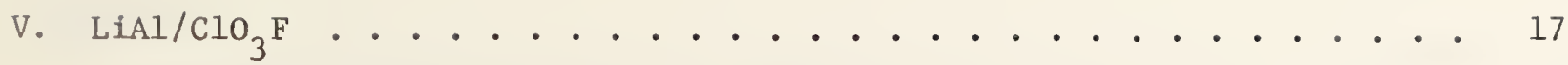

A. Starting Materials . . . .............. . . 17

B. Reaction Products . . . . . . . . . . . . . . 18

C. Mass Spectrometry . . . . . . . . . . . . . . 19

i) Outline of Method . . . . . . . . . . . . 19

ii) Vaporization Considerations . . . . . . . . . . 20

iii) Experimental set-up . . . . . . . . . . . . . 20

iv) Analysis of $\mathrm{ClO}_{3} \mathrm{~F}$. . . . . . . . . . . . . . . 20

v) Reaction of Li-Al Alloy with $\mathrm{ClO}_{3} \mathrm{~F}$. . . . . . . . . 21

vi) $\mathrm{Al}-\mathrm{ClO}_{3} \mathrm{~F}$ Interaction . . . . . . . . . . . . . . 22

D. Kinetics . . . . . . . . . . . . . . . . . 23

E. Enthalpy . . . . . . . . . . . . . . . . . 24

F. Safety Considerations (7) . . . . . . . . . . . . 25

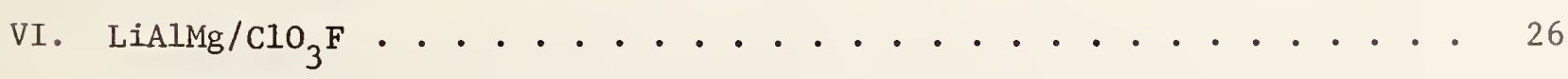

A. Enthalpy . . . . . . . . . . . . . . . . . . 26

B. Safety Considerations . . . . . . . . . . . . . . 27

VII. LiBe/ $\mathrm{ClO}_{3} \mathrm{~F}$. . . . . . . . . . . . . . . . . . . 27

A. Enthalpy . . . . . . . . . . . . . . . . . 27

B. Safety Considerations . . . . . . . . . . . . 28

VIII. $\mathrm{Li} / \mathrm{C}_{11} \mathrm{~F}_{20}$. . . . . . . . . . . . . . . . . 28

A. Starting Materials . . . . . . . . . . . . . . . 28

B. Enthalpy . . . . . . . . . . . . . . . . . 29

C. Safety Considerations . . . . . . . . . . . . . 29 
IX. $\mathrm{LiB} / \mathrm{NF}_{3}$. . . . . . . . . . . . . . . . . . . . . . 29

A. Starting Materials . . . . . . . . . . . . 29

B. Enthalpy . . . . . . . . . . . . . . 29a

C. Safety Considerations . . . . . . . . . . . . . 29a

X. Sumary and Discussion . . . . . . . . . . . . . . . . 30

XI. Needs for Future Research . . . . . . . . . . . . . . 32

XII. References Cited . . . . . . . . . . . . . . . . 34

XIII. Appendix. Results of Literature Survey . . . . . . . . . . 35

XIV. Tables... . . . . . . . . . . . . . . 63

XV. Figures . . . . . . . . . . . . . . . . . 80

XVI. Distribution . . . . . . . . . . . . . . . . 103 


\section{Abstract}

A survey of eight alternative liquid metal stored chemical energy reactions has been made for purposes of comparison with the lithiumaluminum/water, lithium/sulfur hexafluoride, and other reaction schemes. The objective of the study was to survey the potential of these eight reactions as alternate stored chemical energy systems and to develop priorities for future study. Experimental data on the products of reaction and kinetics of reaction are presented for: $\mathrm{Li} / \mathrm{H}_{2} \mathrm{O} ; \mathrm{H}_{2} / \mathrm{O}_{2}$ ), $\left(\mathrm{Li} / \mathrm{H}_{2} \mathrm{O} ; \mathrm{NaO}_{2} / \mathrm{H}_{2} \mathrm{O} ; \mathrm{H}_{2} / \mathrm{O}_{2}\right),\left(\mathrm{MgAl} / \mathrm{H}_{2} \mathrm{O} ; \mathrm{H}_{2} / \mathrm{O}_{2}\right)$, and $\left.\mathrm{LiAl} / \mathrm{ClO}_{3} \mathrm{~F}\right)$. These data have been collected using thermogravimetry and Knudsen effusion mass spectrometry, with $x$-ray diffraction analysis of experimental products. Among other results, the data show that the aluminum component of the fuels is relatively inert to oxidation up to $650^{\circ} \mathrm{C}$. Above this temperature, materials limitations have hampered the collection of experimental data.

Thermodynamic analysis has been used to extend the data on each of the eight reaction schemes, and to predict the chemical reaction which best represents the complete oxidation of each fuel by the indicated oxidant at $1100 \mathrm{~K}$. Enthalpies have been calculated for each fuel/oxidant combination. Safety considerations are also discussed for each. Suggestions for future research are given, including suggestions for overcoming the materials problems encountered in this study. 


\section{Introduction}

Recently there has been much interest in the use of light metals as fuel for stored chemical energy devices. A system currently in usage involves molten lithium metal and sulfur hexafluoride, according to the reaction,

$$
8 \mathrm{Li}+\mathrm{SF}_{6} \rightarrow \mathrm{Li}_{2} \mathrm{~S}+6 \mathrm{LiF}
$$

Under development (1) is a system using lithium aluminum alloy as the fuel and water as the oxidant, according to the reaction:

$$
\mathrm{LiAl}+2 \mathrm{H}_{2} \mathrm{O} \rightarrow \mathrm{LiAlO}_{2}+2 \mathrm{H}_{2}
$$

The hydrogen liberated is combined with oxygen to yield water:

$$
2 \mathrm{H}_{2}+\mathrm{O}_{2} \rightarrow \mathrm{H}_{2} \mathrm{O}
$$

The water produced in this way is returned to [2a] to complete the cycle. In our laboratories investigation is continuing of reaction [2a], which is potentially much more complex than as written (2).

In addition to reaction [2], there are other possible alternate systems of interest and it is desirable to make a preliminary survey of these, to determine if certain ones might emerge as clear choices for further development, or at the least, if others might be eliminated from further consideration. The fuel/oxidant combinations that have been 


$$
\begin{aligned}
& \mathrm{Li} / \mathrm{H}_{2} \mathrm{O} ; \mathrm{H}_{2} / \mathrm{O}_{2} \\
& \mathrm{Li} / \mathrm{H}_{2} \mathrm{O} ; \mathrm{NaO}_{2} / \mathrm{H}_{2} \mathrm{O} ; \mathrm{H}_{2} / \mathrm{O}_{2} \\
& \mathrm{MgAl} / \mathrm{H}_{2} \mathrm{O} ; \mathrm{H}_{2} / \mathrm{O}_{2}
\end{aligned}
$$

$$
\mathrm{LiAl} / \mathrm{ClO}_{3} \mathrm{~F}
$$

$$
\text { LiA1Mg/C10 } 3 \mathrm{~F}
$$

$$
\mathrm{LiBe} / \mathrm{ClO}_{3} \mathrm{~F}
$$

$$
\mathrm{Li} / \mathrm{C}_{11} \mathrm{~F}_{20}
$$

$$
\mathrm{LiB} / \mathrm{NF}_{3}
$$

Combinations [3], [4], and [5] utilize a final stage of combustion in which hydrogen is burned, in a reaction identical to reaction [2b] above. Combinations [6] through [10], however, are envisioned as largely single-stage energy release schemes. To fully evaluate all these candidates it is desirable to have the following basic information:

(a) identity of the products of fuel/oxidant reaction

(b) an indication of the kinetics, especially the minimum temperature required for spontaneous combustion and self-sustaining reaction

(c) an estimate of the enthalpy of reaction

(d) knowledge of toxicity of reaction products

Information collected to date for each of the fuel/oxidant combinations is summarized in the paragraphs that follow. Most experiments were com- 
pleted using a Mettler ${ }^{1}$ thermoanalysis system, except for reaction [6], which was also investigated mass spectrometrically. Following a presentation of data for each of the above reaction schemes, a general discussion and recommendations for follow-up research are given. Results of a literature search are given in an Appendix (Section XIII).

II. $\mathrm{Li} / \mathrm{H}_{2} \mathrm{O} ; \mathrm{H}_{2} / \mathrm{O}_{2}$

\section{A. Starting Materials and Container Materials}

The starting material used for these experiments was finely powdered 1ithium metal ( -140 mesh, $99.95 \%$ pure on a metal basis). This material had some surface oxidation upon receipt from the vendor, causing it to have a slightly grayish cast; the contaminants were tentatively identified as lithium carbide $\left(\mathrm{Li}_{2} \mathrm{C}_{2}\right)$, lithium hydride, and lithium hydroxide, on the basis of weak x-ray diffraction peaks. All materials handling operations involving the lithium metal were completed in a glove box. Quantitative study of the oxidation of metallic lithium poses special materials problems. Any container must be capable of withstanding attack by both metallic lithium and the oxidant. Silica glass is not a suitable container in the presence of both the lithium fuel and the water oxidant. Graphite and molybdenum are mentioned in the literature $(3,4)$ as container materials for lithium alloys; however both are attacked by oxidants at relatively low temperatures. A nickel-based alloy would appear to offer promise; however, nickel could

\footnotetext{
TCertain commercial equipment, instruments, or materials are identified in this paper in order to adequately specify the experimental procedure. Such identification does not imply recommendation or endorsement by the National Bureau of Standards, nor does it imply that the materials or equipment identified are necessarily the best available for the purpose.
} 
be expected to undergo a certain degree of oxidation even at relatively low temperatures, affecting the results of sensitive thermogravimetric experiments, and possibly contaminating the sample. BN is a possible material, but experiments with LiAl (see below) suggest lithium abosrption. Perhaps the strongest candidate crucible materials for future work are $\mathrm{BeO}$ (5) and $\mathrm{MgO}$; however, as these were not available, all measurements to date were completed using readily available alumina crucibles at temperatures below the melting point of lithium metal.

\section{B. Reaction Products}

Lithium metal was reacted with water-saturated flowing argon $\left(30,000 \mathrm{ppm} \mathrm{H}_{2} \mathrm{O}\right)$ in the thermoanalyzer. At $25^{\circ} \mathrm{C}$, slow reaction of lithium metal with water produces $\mathrm{LiOH} . \mathrm{H}_{2} \mathrm{O}$. However the reaction probably proceeds sequentially, starting with LiOH, as evidenced by $x$-ray analysis of samples from different zones within the reaction cell. Near the bottom of the cell, products were largely LiOH; near the top, the hydrate was dominant. At $100^{\circ} \mathrm{C}$, the reaction product is almost entirely LiOH; small amounts of the hydrate are believed to have formed as the experiment cooled.

\section{Kinetics}

The finely powdered lithium metal used in these expeiments is highly reactive at room temperature in spite of the thin surface coating. This is evidenced by rapid reaction when deliberately exposed to the atmosphere. When placed in contact with water, violent reaction ensues, and explosion occurs due to spontaneous ignition of the evolved hydrogen. 
In the thermoanalyzer experiments, the reaction was purposefully set up to proceed in controlled fashion. Reaction curves at 25 and $100{ }^{\circ} \mathrm{C}$ are shown in Fig. 1. The $25^{\circ} \mathrm{C}$ curve shows a nearly linear segment from 0 to 1500 min. of reaction time, implying that reaction control in the early stages is not associated with build-up of a product layer, but rather may be linked to the rate of supply of the water vapor. The second half of the $25^{\circ} \mathrm{C}$ curve is nonlinear. This could be due to the influence of the product layer of $\mathrm{LiOH}_{\mathrm{H}} \mathrm{O}$, but is more likely to be due to the increased diffusion path required for vapor to reach the powders in the bottom of the cell. The reaction was stopped prior to completion. Theoretically completion would have occurred at a fractional weight gain of 5.1 (compared with 3.7 at the termination of the experiment). This number assumes complete conversion to $\mathrm{Li}(\mathrm{OH}) \cdot \mathrm{H}_{2} \mathrm{O}$. By contrast, at $100^{\circ} \mathrm{C}$, the entire curve appears to be nonlinear. This suggests influence of the product layer (in this case LiOH). The reaction appears to have terminated in spite of the fact that the theoretical fractional weight gain of 2.5 was not reached. This probably indicates that the surface contamination of the Li powdered starting material is more severe than the $\mathrm{x}$-ray analysis suggested. Future experiments will employ a much more nearly pure lithium powder.

\section{Enthalpy}

Thermodynamic data for calculation of the enthalpy of oxidation of molten lithium metal by $\mathrm{H}_{2} \mathrm{O}$ are available in the JANAF tables (6). Enthalpy production in kcal per gram of fuel plus oxidant can be calculated, if the lithium oxidation reaction is combined with burning of the evolved hydrogen and recycling of water thus produced: 


$$
\begin{gathered}
\mathrm{Li}+\mathrm{H}_{2} \mathrm{O} \rightarrow \mathrm{LiOH}+(1 / 2) \mathrm{H}_{2} \\
(1 / 2) \mathrm{H}_{2}+(1 / 4) \mathrm{O}_{2} \rightarrow(1 / 2) \mathrm{H}_{2} \mathrm{O} \\
\mathrm{Li}+(1 / 2) \mathrm{H}_{2} \mathrm{O}+(1 / 4) \mathrm{O}_{2} \rightarrow \mathrm{LiOH} \text { (combined reaction) }
\end{gathered}
$$

The calculated value ${ }^{2}$ at $1100 \mathrm{~K}\left(827^{\circ} \mathrm{C}\right)$ is $3.5 \mathrm{kcal} / \mathrm{g}$. If LiOH did not form, the combined reaction would be:

$$
2 \mathrm{Li}+(1 / 2) \mathrm{O}_{2} \rightarrow \mathrm{Li}_{2} \mathrm{O}
$$

for which the enthalpy yield is $4.8 \mathrm{kcal} / \mathrm{g}$. Clearly there is a heavy energy penalty paid by loss of hydrogen in the cycle to form LiOH.

\section{E. Safety Considerations (7)}

Lithium metal reacts exothermically with the moisture in human tissue, causing both thermal and chemical burns. An explosion hazard exists when the metal is exposed to moisture of any form, or to any other oxidizing material. When heated in air or burned it emits toxic fumes of $\mathrm{Li}_{2} \mathrm{O}$ and $\mathrm{LiOH}$. It reacts with nitrogen at high temperatures.

III. $\mathrm{Li} / \mathrm{H}_{2} \mathrm{O} ; \mathrm{NaO}_{2} / \mathrm{H}_{2} \mathrm{O} ; \mathrm{H}_{2} / \mathrm{O}_{2}$

\section{A. Starting Materials}

The $\mathrm{Li} / \mathrm{H}_{2} \mathrm{O}$ part of the reaction scheme has been discussed above. The role of $\mathrm{NaO}_{2}$ is to provide oxygen for the second stage burning of hydrogen.

2All energy yield calculations in this report are listed in terms of kcal per gram of fuel plus oxidant. 
The $\mathrm{NaO}_{2}$ used in these experiments was indicated by the vendor to be $95 \% \mathrm{NaO}_{2}$. X-ray powder diffraction analysis of the starting material which consisted of pale yellow granules, yielded a very complex pattern containing peaks for $\mathrm{NaOH}, \mathrm{NaO}_{2}(\mathrm{I})$ and several unidentified peaks.

\section{B. Reaction Products}

$\mathrm{NaO}_{2}$ was placed in a platinum cell in the thermoanalyzer. The sample was brought to temperature $\left(25\right.$ or $100{ }^{\circ} \mathrm{C}$ ) and then a stream of flowing water-saturated argon $\left(30,000 \mathrm{ppm} \mathrm{H}_{2} \mathrm{O}\right)$ was introduced. At the conclusion of the $100{ }^{\circ} \mathrm{C}$ experiment the sample was $\mathrm{x}$-rayed. This was not possible for the $25^{\circ} \mathrm{C}$ experiment, which produced liquid; apparently the $\mathrm{NaO}_{2}$ (or the $\mathrm{NaOH}$ produced from it) is deliquescent at $25^{\circ} \mathrm{C}$. The $100{ }^{\circ} \mathrm{C}$ experiment yielded predominantly $\mathrm{NaOH}$; the lesser amount of $\mathrm{NaOH} \cdot \mathrm{H}_{2} \mathrm{O}$ present is thought to have formed as the experiment cooled.

\section{Kinetics}

Reaction curves for $\mathrm{NaO}_{2} / \mathrm{H}_{2} \mathrm{O}$ at 25 and $100{ }^{\circ} \mathrm{C}$ are shown in Fig. 2 . The $25^{\circ} \mathrm{C}$ curve consists of two linear weight gain portions. Interestingly the slope increases for the later segment. This is interpreted as follows. During the early $25^{\circ} \mathrm{C}$ segment, the reaction involves loss of oxygen and gain of water:

$$
2 \mathrm{NaO}_{2}+3 \mathrm{H}_{2} \mathrm{O} \rightarrow 2\left(\mathrm{NaOH} \cdot \mathrm{H}_{2} \mathrm{O}\right)+(3 / 2) \mathrm{O}_{2}
$$

The theoretical fractional weight gain for this reaction is 0.06 , which is near the change in slope for the $25^{\circ} \mathrm{C}$ curve. During the later segment of the $25^{\circ} \mathrm{C}$ reaction curve in Fig. 2, the product is thought to be the deliquescent liquid observed at the conclusion of the experiment, produced according to the reaction: 
$\mathrm{NaOH} \cdot \mathrm{H}_{2} \mathrm{O}+\mathrm{H}_{2} \mathrm{O} \rightarrow\left(\mathrm{NaOH}, \mathrm{H}_{2} \mathrm{O}\right)(\ell)$

Possibly formation of the liquid results in increased accessibility by the gas, explaining the increased slope.

At $100{ }^{\circ} \mathrm{C}$, the reaction of $\mathrm{NaO}_{2}$ with water vapor produces a nearly linear weight loss as would be expected from the reaction:

$$
2 \mathrm{NaO}_{2}+\mathrm{H}_{2} \mathrm{O} \rightarrow 2 \mathrm{NaOH}+(3 / 2) \mathrm{O}_{2}
$$

This reaction would yield a theoretical weight loss of 0.27 . The $100{ }^{\circ} \mathrm{C}$ reaction apparently terminates at less than this value, reflecting the presence of the $\mathrm{NaOH}$ impurity noted in the $\mathrm{x}$-ray analysis of the starting materials.

\section{Enthalpy}

If the sodium superoxide reaction is combined with the lithium/water oxidization reactions, we have the following:

$$
\begin{aligned}
& (1 / 3) \mathrm{NaO}_{2}+(1 / 6) \mathrm{H}_{2} \mathrm{O} \rightarrow(1 / 3) \mathrm{NaOH}+(1 / 4) \mathrm{O}_{2} \\
& \mathrm{Li}+(1 / 2) \mathrm{H}_{2} \mathrm{O}+(1 / 4) \mathrm{O}_{2} \rightarrow \mathrm{LiOH} \\
& (1 / 3) \mathrm{NaO}_{2}+(2 / 3) \mathrm{H}_{2} \mathrm{O}+\mathrm{Li} \rightarrow(1 / 3) \mathrm{NaOH}+\mathrm{LiOH} \\
& \text { (combined reaction) }
\end{aligned}
$$

An enthalpy of formation for $\mathrm{NaO}_{2}$ at $298 \mathrm{~K}$ can be estimated as $-62.7 \mathrm{kcal}$. 
Neglecting the heat required to bring the oxygen from the first stage up to $1100 \mathrm{~K}$, the total energy release in reaction [20] is $-2.2 \mathrm{kcal} / \mathrm{g}$. This is significantly less than the $-3.5 \mathrm{kcal} / \mathrm{g}$ calculated earlier for the $\mathrm{Li} / \mathrm{H}_{2} \mathrm{O} ; \mathrm{H}_{2} / \mathrm{O}_{2}$ combination. However it may be that there are advantages associated with use of a solid as the oxidant source rather than a compressed gas.

\section{E. Safety Considerations (7)}

Hazards associated with lithium are noted in the discussion of $\mathrm{Li} / \mathrm{H}_{2} \mathrm{O}$ above. Sodium superoxide has much the same toxicity as $\mathrm{NaOH}$, which it forms upon contact with moisture. Contact with skin could be expected to cause burns and ulceration; inhalation of the mist or powder could cause damage to the upper respiratory tract and lungs. Heating could cause violent decomposition. Contact with moisture or reducing agents could result in explosion.

IV. $\mathrm{MgAl} / \mathrm{H}_{2} \mathrm{O} ; \mathrm{H}_{2} / \mathrm{O}_{2}$

\section{A. Starting Materials}

Magnesium aluminum alloy of $50 / 50$ atomic ratio was prepared in the NBS metals processing lab by melting high purity magnesium and aluminum together under a halide flux and casting the melt into a steel chill mold. The resulting ingot was very brittle and was easily crushed in a mortar and pestle in a glove box. A $(-200,+400)$ sieve fraction was then prepared for the experiment and stored in the glove box until use. An x-ray diffraction pattern showed characteristic peaks for $\mathrm{Al}_{2} \mathrm{Mg}_{3}$ with a few additional unidentified peaks of low intensity. 


\section{B. Reaction Products}

The powdered alloy was placed in an alumina cell in a glove gox and transferred to the thermoanalyzer system. Next the specimen was brought to $650{ }^{\circ} \mathrm{C}$ in an argon atmosphere. At this temperature the specimen was completely melted, according to the $\mathrm{Mg}-\mathrm{Al}$ phase diagram (8). Next, argon saturated with water at $25^{\circ} \mathrm{C}\left(30,000 \mathrm{ppm} \mathrm{H}_{2} \mathrm{O}\right)$ was flowed continuously over the sample. At the conclusion of reaction the gray, porous sample was cooled, removed and $\mathrm{x}$-rayed. The $\mathrm{x}$-ray powder pattern showed strong peaks for aluminum metal and Mgo (periclase). Apparently only the magnesium component of the molten alloy was oxidized, as there were no peaks for $\mathrm{Al}_{2} \mathrm{O}_{3}, \mathrm{MgAl}_{2} \mathrm{O}_{4}$ or any other aluminous phases.

\section{Kinetics}

Rate data for the oxidation of molten MgAl by water vapor are shown in Fig. 3. The meaning of the step in the weight gain curve at about 100 minutes of reaction time is not clear. However the two segments of this curve on either side of the break have substantially linear portions, suggesting that diffusion through a product layer of increasing thickness is not a controlling factor during most of the reaction. The reaction appears to slow to a very low rate as the fraction reacted approaches 0.30. This is in agreement with the $\mathrm{x}$-ray analysis, which indicates essentially all the Mg has been oxidized; complete oxidation of the Mg to periclase would correspond to a fractional weight gain of 0.31 , very close to that observed; on the other hand, complete oxidation of both the magnesium and the aluminum would result in a fractional weight gain of 0.62 .

\section{Entha1py}

Referring to the system $\mathrm{Mg}-\mathrm{Al}-\mathrm{O}-\mathrm{H}$, at least three possible oxidation reactions involving the $1: 1$ alloy and water could occurr. These are 
summarized below:

$$
\begin{aligned}
& 2 \mathrm{MgAl}+5 \mathrm{H}_{2} \mathrm{O} \rightarrow \mathrm{MgO}+\mathrm{MgAl}_{2} \mathrm{O}_{4}+5 \mathrm{H}_{2} \\
& 5 \mathrm{H}_{2}+(5 / 2)_{2} \rightarrow 5 \mathrm{H}_{2} \mathrm{O} \\
& 2 \mathrm{MgAl}+5 \mathrm{H}_{2} \mathrm{O} \rightarrow 2 \mathrm{MgO}+\mathrm{Al}_{2} \mathrm{O}_{3}+5 \mathrm{H}_{2} \\
& 5 \mathrm{H}_{2}+(5 / 2) \mathrm{O}_{2} \rightarrow 5 \mathrm{H}_{2} \mathrm{O} \\
& \mathrm{MgAl}_{2}+\mathrm{H}_{2} \mathrm{O} \rightarrow \mathrm{MgO}+\mathrm{Al}+\mathrm{H}_{2} \\
& \mathrm{H}_{2} \mathrm{O}+(1 / 2) \mathrm{O}_{2} \rightarrow \mathrm{H}_{2} \mathrm{O}
\end{aligned}
$$

To complete enthalpy calculations for these reactions an estimate for the enthalpy of formation of molten MgAl was made using the ideal solution approximation. Calculated enthalpy release values for the three reaction pairs are respectively, $-3.8,-3.8$, and $-2.2 \mathrm{kcal} / \mathrm{g}$. Clearly, formation of spinel (reaction [2la] vs. reaction [22a]) affects the energy yield very little. Reaction [23a] has been included because it is the one observed, and clearly its occurrence instead of [21a] or [22a] results in substantially lower energy yield. Presumably at some higher temperature the aluminum component will begin to react according to reaction [21a] or [22a].

\section{E. Safety Considerations (7)}

Hazards data are not available for MgAl alloy. Aluminum is not regarded as a poison, although inhalation of finely divided powders can damage the lungs. Magnesium on the other hand can cause chemical gas 
gangrene if it enters the body, due to generation of hydrogen. Fine magnesium powder readily ignites by exposure to spark or flame.

V. $\mathrm{LiAl} / \mathrm{ClO}_{3} \mathrm{~F}$

\section{A. Starting Materials}

The starting material for these experiments was powdered LiAl. The material as received was packed under argon and visually showed no signs of surface contamination--all surfaces were bright and shiny. X-ray analysis showed only peaks of LiA1. A11 manipulations involving this material were done in a glove gox through which a continuously purified argon atmosphere was recirculated. The material used in these experiments was a $(-200,+400)$ sieve fraction. Transfer to the thermoanalyzer was accomplished in a glove bag, flushed repeatedly with purified argon.

The $\mathrm{ClO}{ }_{3} \mathrm{~F}$ (perchloryl fluoride) was obtained from the vendor in cylinders containing either $100 \mathrm{~g}$ or $250 \mathrm{~g}$. Principal impurities were $\mathrm{N}_{2}, \mathrm{O}_{2}, \mathrm{CO}_{2}, \mathrm{H}_{2} \mathrm{O}$ and $\mathrm{HF}$ (see section on mass spectrometry).

Gas was run through a corrosive gas regulator and then through a column containing $\mathrm{NaOH}$ pellets and molecular sieve, and finally through a flowmeter and then into the thermoanalyzer. The $\mathrm{ClO}_{3} \mathrm{~F}$, a very dense gas, was piped directly into the crucibles in the thermoanalyzer exper-

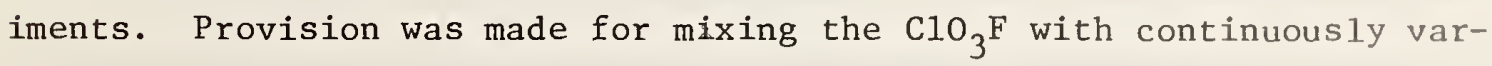
iable amounts of argon. However, all thermoanalyzer experiments reported were carried out using a flow of pure $\mathrm{ClO}_{3} \mathrm{~F}$ since it was discovered that the reactions proceeded in controlled fashion so that no argon dilution was necessary. Although argon was used to flush the balance components 
during the experiments, it is estimated that the effective partial pressure of $\mathrm{ClO}_{3} \mathrm{~F}$ over the specimens during these experiments was close to 1 atmosphere.

\section{B. Reaction Products}

Initially, experiments were conducted in alumina crucibles; however these were unsatisfactory above $700{ }^{\circ} \mathrm{C}$, owing to the corrosiveness of the molten alloy. Crucibles of $\mathrm{LiAlO}_{2}$ have been fabricated and these appear to offer promise for application in higher temperature experiments. Additionally $\mathrm{MgO}$ and $\mathrm{BeO}$ offer promise. Boron nitride crucibles were fabricated and tested in contact with LiAl at $800{ }^{\circ} \mathrm{C}$. They seem to hold up to attack by the molten alloy well, except for a slight discoloration, which may be associated with diffusion of $\mathrm{Li}$. Also a steady and extensive weight gain of the crucible occurred during preliminary tests under an atmosphere of purified argon. As we have no explanation for or solution to this problem, use of the BN crucibles was discontinued. Calciastabilized zirconia and silica glass crucibles were employed for the mass spectrometric studies, with mixed results. All other experiments reported employed alumina crucibles.

At the conclusion of the $\mathrm{LiAl} / \mathrm{ClO}_{3} \mathrm{~F}$ experiments, crucibles were removed and placed in an inert atmosphere. X-ray mounts were prepared in the glove box and $x$-rayed under flowing $N_{2}$. Results of x-ray analysis are indicated in Table 1 , below.

As can be seen from Table 1 , experimental results vary greatly depending upon experimental conditions. The following generalizations can be made, however, for the range of conditions investigated (350$650{ }^{\circ} \mathrm{C}, \mathrm{P}_{\mathrm{ClO}} \mathrm{F}=1$ atm; or, $900{ }^{\circ} \mathrm{C}, \mathrm{P}_{\mathrm{C} 10_{3} \mathrm{~F}}=10^{-5}$ atm). 
(1) Fluorides ( $\left.\mathrm{Li}_{3} \mathrm{AlF}_{6}, \mathrm{AlF}_{3}, \mathrm{LiF}\right)$ appear to be by far the dominant reaction products.

(2) Chlorides may form during initial stages of oxidation $^{3}$ (see discussion of kinetics) but are relatively minor phases in the end products.

(3) The lithium in the alloy is preferentially oxidized leaving behind aluminum which behaves as though inert (see also discussion of MgAl oxidation).

(4) The occurrence of oxides as oxidation products is limited in these experiments to low partial pressures of $\mathrm{ClO}_{3} \mathrm{~F}$ and/or high temperatures.

\section{Mass Spectrometry}

i) Outline of Method

In this technique, the Li-Al alloy contained in a Knudsen cell is exposed to $\mathrm{ClO}_{3} \mathrm{~F}$ introduced into the cell through a gas inlet system. At appropriate temperatures, reaction products undergo vaporization into the source of the mass spectrometer where the gaseous products are ionized and mass analyzed. The major advantage of this method is that it can in principle detect gaseous reaction products. A second advantage is that the number of collisions of reactant vapor with the condensed phase may be controlled at a low value so that the kinetics of the process can be substantially solved.

In the present measurements, however, it was found that reaction rates are quite slow even up to temperatures as high as $1000{ }^{\circ} \mathrm{C}$ so that modifications in the experimental arrangement to enhance reaction rates will be advantageous. 
ii) Vaporization Considerations

At low temperatures some of the reaction products may be relatively non-volatile so that they will not be detected by mass spectrometric analysis. On the basis of data in the literature, the metal chlorides are more volatile than the metal fluorides while the metal oxides are non-volatile up to temperatures of $1000{ }^{\circ} \mathrm{C}$ or so. Also, because the halides will form a salt solution, complexing to form interhalide compounds may influence the volatity of the solution. For example, formation of $\mathrm{LiAlCl}_{4}$ would greatly reduce the pressure expected from formation of $\mathrm{AlCl}_{3}$

iii) Experimental set-up

These measurements were made using a fused silica effusion sampler. The Li-Al alloy was contained in a calcia-stabilized zirconia cup supported within the effusion sampler. The $\mathrm{ClO}_{3} \mathrm{~F}$ was delivered to the gas inlet tube through a small leak valve. The Li-Al alloy was loaded into the zirconia cell in a dry-box then transferred to the mass spectrometer under argon to reduce the reaction of the Li-Al alloy with ambient water vapor.

An effusion orifice of $1 \mathrm{~mm}$ diameter was used in the effusion sampler. This proved to be too large as the $\mathrm{ClO}_{3} \mathrm{~F}$ reacted much less rapidly with the Li-A1 alloy than expected.

The control valve was attached to the $\mathrm{C} 10_{3} \mathrm{~F}$ cylinder in the dry box so the $\mathrm{ClO}_{3} \mathrm{~F}$ was diluted with Ar during the earlier parts of the experiment.

iv) Analysis of $\mathrm{ClO}_{3} \mathrm{~F}$

Mass spectrometric sampling of the commercial $\mathrm{ClO}_{3} \mathrm{~F}$ gas showed predominant peaks at m/e values of $104,102,85,83,69,67,53$, and 51 corresponding to the ${ }^{37} \mathrm{Cl}$ and ${ }^{35} \mathrm{Cl}$ isotopes of the species $\mathrm{ClO}_{3} \mathrm{~F}^{+}$, 
$\mathrm{ClO}_{3}{ }^{+}, \mathrm{ClO}_{2}{ }^{+}$, and $\mathrm{ClO}^{+}$. Except for $\mathrm{ClO}_{3} \mathrm{~F}^{+}$, these peaks are due to fragmentation of the $\mathrm{ClO}_{3} \mathrm{~F}$ during the ionization process using electrons at 30v. Besides the $\mathrm{ClO}_{3} \mathrm{~F}$, Ar which was introduced from the dry box installation of the regulator was also observed. By comparing the mass spectrum with the $\mathrm{ClO}_{3} \mathrm{~F}$ gas flow on or off, it was determined that the $\mathrm{ClO}_{3} \mathrm{~F}$ also contained a small amount (perhaps a percent or so) of air $\left(\mathrm{N}_{2}, \mathrm{O}_{2}, \mathrm{CO}_{2}\right.$, and $\mathrm{H}_{2} \mathrm{O}$ ). The $\mathrm{H}_{2} \mathrm{O}$ had apparently partially reacted with the steel cylinder and produced slight traces of $\mathrm{HF}$ (mass 20), $\mathrm{H}^{35} \mathrm{Cl}$ (36), and $\mathrm{H}^{37} \mathrm{Cl}$ (38). However, it is not likely that the contamination had significant effect on the reaction of $\mathrm{ClO}_{3} \mathrm{~F}$ with the alloy.

v) Reaction of Li-Al Alloy with $\mathrm{ClO}_{3} \mathrm{~F}$

The first mass peaks due to reaction of $\mathrm{ClO}_{3} \mathrm{~F}$ with the Li-Al alloy were observed at $420{ }^{\circ} \mathrm{C}$. These peaks were $\mathrm{Li}^{+}$from fragmentation of $\mathrm{LiCl}(\mathrm{g})$, $\mathrm{LiCl}^{+}$from ionization of the $\mathrm{LiCl}(\mathrm{g})$ and $\mathrm{Li}_{2} \mathrm{Cl}^{+}$, from ionization of the $\mathrm{Li}_{2} \mathrm{Cl}_{2}(\mathrm{~g})$ parent.

One might expect $\mathrm{A} 1-\mathrm{Cl}$ species in this temperature range but none were observed, in spite of the fact that loss of volatile substances is indicated by the analogous thermogravimetric experiment. It is clear from the presence of both $\mathrm{LiCl}(\mathrm{g})$ and $\mathrm{Li}_{2} \mathrm{Cl}_{2}(\mathrm{~g})$ that a condensed halide phase was formed on the sampler.

With time, the ratio of $\mathrm{LiCl}^{+} / \mathrm{Li}_{2} \mathrm{Cl}^{+}$gradually increased. This probably showed that LiF was also forming in the condensed phase and reducing the activity of LiCl. At $600{ }^{\circ} \mathrm{C}, \mathrm{Li}_{2} \mathrm{~F}^{+}$from the fragmentation of $\mathrm{Li}_{2} \mathrm{~F}_{2}$ was observed in the mass spectrum. Over the temperature range from $600-900{ }^{\circ} \mathrm{C}$ ions corresponding to parent molecules $\mathrm{LiCl}, \mathrm{Li}_{2} \mathrm{Cl}_{2}$, $\mathrm{LiF}$, and $\mathrm{Li}_{2} \mathrm{~F}_{2}$ were observed. It did not appear that any $\mathrm{Al}$ bearing species were formed in the gas phase. 
At the conclusion of the experiment, the Li-Al alloy still had a powdery appearance even through it had been heated several hundred degrees above the melting point.

An x-ray diffraction pattern of the residue revealed the presence of $\mathrm{LiAlO}_{2}$ with perhaps an equal amount of unreacted Al (see Table 1). vi) $\mathrm{Al}_{-} \mathrm{ClO}_{3} \mathrm{~F}$ Interaction

Because Al bearing species were not observed from the Li-Al alloy, a mass spectrometric experiment was carried out using only powdered Al in the effusion cell. The purpose of this experiment was to see if it was possible to form $\mathrm{Al}$ bearing species by reactions with $\mathrm{C} 10_{3} \mathrm{~F}$. Near $500{ }^{\circ} \mathrm{C}$ species corresponding to the halide ions $\mathrm{AlF}^{+}, \mathrm{AlCl}^{+}, \mathrm{AlF}_{2}^{+}$, $\mathrm{AlClF}^{+}, \mathrm{Al}_{3}^{+}, \mathrm{AlF}_{2} \mathrm{Cl}^{+}, \mathrm{AlCl}_{2} \mathrm{~F}^{+}$, and $\mathrm{AlCl}_{3}{ }^{+}$were observed. Because of the number of complex species in the vapor phase, the existence of a condensed phase at this temperature consisting of mainly $\mathrm{AlF}_{3}$ seems likely. The duration of the experiment during which Al-halide species was generated was quite short. All of the Al bearing species decreased with time and increasing the $\mathrm{C} 10_{3} \mathrm{~F}$ flow rate and the temperature had no effect on increasing their intensity. This seems to indicate that the chlorination and fluoridation processes took place at only selected sites in the Al powder which were gradually depleted or lost, perhaps because of oxidation.

At $760{ }^{\circ} \mathrm{C}$, most of the $\mathrm{Al}$ halide peaks had vanished except for $\mathrm{AlF}_{2}{ }^{+}$which is a major fragmentation product of $\mathrm{AlF}_{3}(\mathrm{~g})$. The experiment was terminated after a brief heating period at $800{ }^{\circ} \mathrm{C}$. Visual examination of the residue at the conclusion of the experiment revealed that most of the sample still had a powdery texture but a few small spheres resulting from melting the sample were also present. Since the sample 
was heated to about $150^{\circ} \mathrm{C}$ above the melting point of $\mathrm{Al}$, the powdery texture of the sample must result from an oxide skeleton on the outside surface of each grain in the powder. The sample initially weighed $118 \mathrm{mg}$ and gained $2.2 \mathrm{mg}$ during the experiment, despite loss of the halides, indicating that a small amount of oxidation took place.

\section{Kinetics}

Thermogravimetric rate data for the reaction of LiAl with $\mathrm{ClO}_{3} \mathrm{~F}$ are shown in Fig. 4 at temperatures of $350,450,550$ and $650{ }^{\circ} \mathrm{C}$. It is presumed on the basis of the Li-Al phase diagram (9) that the LiAl was solid during these experiments. With the exception of the $350{ }^{\circ} \mathrm{C}$ experiment, rate curves all initially show a rapid weight gain at a nearly steady rate. This continues until a weight fraction gain of between 0.5 and 0.7 has been reached. At this point the rate of weight gain decreases for a short time and then increases again. This behavior is especially pronounced in the $650^{\circ} \mathrm{C}$ experiment, where a small weight loss with time is apparent, followed by an increase in the rate of weight gain. This weight loss (and possibly, as well, the temporary decrease in rate of gain at all four temperatures) is best interpreted as due to formation of a volatile reaction product, most probably $\mathrm{AlCl}_{3} \cdot$ Continued reaction leads to a similar ultimate weight gain of between 0.9 and 1.1 for experiments at all four temperatures, 350, 450, 550 and $560{ }^{\circ} \mathrm{C}$ (see Table 1). This is true in spite of the fact that the products are somewhat different in each case. Table 2 lists hypothetical reactions of LiAl with $\mathrm{Cl}, \mathrm{O}$ and $\mathrm{F}$ and combinations thereof, together with theoretical weight gains. These reactions have been derived with the aid of thermodynamically calculated equilibrium phase compatibilities shown in Fig. 7. Calculated weight gains are highly variable, but the partial 
experimental products observed (Table 1). The fractional weight gains calculated for these reactions are 0.56 and 1.12 , respectively, encompassing the range observed.

It seems likely from the curves in Fig. 4 that more than one reaction has occurred during the oxidation of LiAl by $\mathrm{ClO}_{3} \mathrm{~F}$. It also seems likely that early stage condensed phase products undergo subsequent reaction with time to yield a new generation of products. In future experiments, reacion of LiAl with $\mathrm{ClO}_{3} \mathrm{~F}$ will be completed at higher temperatures, where hopefully a rapid approach to equilibrium will eliminate many of these complications. It is hoped that mass spectrometer measurements will be carried out at higher pressures of $\mathrm{ClO}_{3} \mathrm{~F}$ using a transpiration system.

\section{E. En thalpy}

From Table 1 it can be seen that the reaction products at temperatures of $650{ }^{\circ} \mathrm{C}$ and below differ greatly, depending upon temperature. Further, oxidation of the alloy is far from complete, and the majority of the aluminum component of the alloy appears to have remained in the metallic state. The reaction products suggest disequilibrium among themselves; for example, $\mathrm{Li}_{3} \mathrm{AlF}_{6}, \mathrm{AlF}_{3}$ and $\mathrm{LiF}$ are not in stable equilibrium together. The principal difficulty then is in extrapolating these limited results to a higher temperature such as $1100 \mathrm{~K}$, at which oxidation could be expected to be much more complete, so that a meaningful enthalpy yield calculation can be done.

The LiAl/ $\mathrm{ClO}_{3} \mathrm{~F}$ reaction can be described by the five component chemical system Li-Al-C1-O-F. Fortunately thermodynamic data are available for many of the end-member compounds in this system and so a preliminary thermodynamic analysis can be completed. This results in an 
estimated equilibrium reaction for complete oxidation which can be used to calculate enthalpy yield. The thermodynamic analysis was completed as follows. Fig. 5 depicts graphically the compositional regions of interest in the three principal quaternary subsystems contained within the five component system. Fig. 6 shows calculated phase compatibilities for important ternary reciprocal systems in Fig. 5. These compatibilities are schematic and indicate major features of phase equilibria which are consistent with known thermodynamic data, according to the reactions in Table 3. On the basis of Fig. 6, Fig. 7 has been constructed. This shows calculated equilibrium relations at $1100 \mathrm{~K}$ for the phase regions shown in Fig. 5. Based on Fig. 6 and 7, Fig. 8 has been constructed, showing calculated equilibrium relations at $1100 \mathrm{~K}$ among phases most likely to form as products of complete reaction of $\mathrm{LiAl}$ and $\mathrm{ClO}_{3} \mathrm{~F}$. The reaction suggested by Fig. 8 is:

$$
2 \mathrm{LiAl}+\mathrm{ClO}_{3} \mathrm{~F} \rightarrow \mathrm{Al}_{2} \mathrm{O}_{3}+\mathrm{LiF}+\mathrm{LiCl}
$$

It should be emphasized that there is no direct experimental evidence yet in support of this reaction: however on purely thermodynamic grounds it is the favored reaction. To complete the enthalpy calculation, data for LiAl were estimated using the ideal solution approximation. The resulting value of enthalpy yield for this reaction is $3.8 \mathrm{kcal} / \mathrm{g}$.

\section{F. Safety Considerations (7)}

Safety hazards associated with LiAl are similar to those associated with $\mathrm{Li}$ as noted above, although reaction with moisture is considerably less vigorous at room temperature. Perchloryl fluoride is a highly toxic gas which causes symptoms of asphyxiation and poisoning similar to 
$\mathrm{CO}$, although recovery is said to be rapid provided exposure has not been prolonged. The gas has a sweet odor, but this cannot be relied upon to indicate toxic concentrations. Perchloryl fluoride is readily absorbed through the skin. Although nonflammable, it does support combustion, as it is a powerful oxidizer. When heated to decomposition, it emits highly toxic fumes of chlorides and fluorides.

VI. $\mathrm{LiAlMg} / \mathrm{ClO}_{3} \mathrm{~F}$

\section{A. Enthalpy}

At the time of writing, experiments have not yet been completed in this system, owing to lack of available starting material. Therefore enthalpy yield estimates must be made solely on the basis of preliminary thermodynamic analysis. The fuel/oxidant reaction is represented by the 6-component system $\mathrm{Li}-\mathrm{Al}-\mathrm{Mg}-\mathrm{Cl}-\mathrm{O}-\mathrm{F}$. The phase equilibrium topology is of course impossible to represent in three dimensions; nonetheless, progress can be made by consideration of the six quaternary reciprocal systems shown in Fig. 9. By calculation of the reactions in Table 4, the schematic ternary phase compatibilities shown in Fig. 10 have been derived. From additional reactions in Table 4 and compatibilities in Fig. 10, construction of Figs. 11 and 12 was made possible. Fig. 11 pertains to progressive chlorination, fluorination or oxygenation of fuel. Fig. 12 relates to the equilibrium products of complete reaction. Table 5 gives some postulated equilibrium reactions involving progressive reaction of LiAlMg fuel with $\mathrm{Cl}, \mathrm{F}, \mathrm{O}$ and combinations thereof.

Based on the above considerations, the following is thought to represent complete reaction of LiAlMg alloy ( $1: 1: 1$ atomic) with $\mathrm{ClO}_{3} \mathrm{~F}$ : 
$4 \mathrm{LiAlMg}+3 \mathrm{ClO}_{3} \mathrm{~F} \rightarrow \mathrm{MgF}_{2}+\mathrm{LiF}+3 \mathrm{LiCl}+2 \mathrm{MgAl}_{2} \mathrm{O}_{4}+\mathrm{MgO}$

The calculated enthalpy yield for this reaction at $1100 \mathrm{~K}$ is $3.6 \mathrm{kcal} / \mathrm{g}$.

B. Safety Considerations (7)

Safety hazards are similar to those noted for LiAlMg/C10 $\mathrm{F}$ above.

VII. LiBe $/ \mathrm{ClO}_{3} \mathrm{~F}$

\section{A. Enthalpy}

Because of the toxicity of beryllium and beryllium compounds, experiments have not been conducted on the oxidation of lithium-beryllium alloy by $\mathrm{ClO}_{3} \mathrm{~F}$. Hence any estimate of enthalpy release must rely soley upon thermodynamic estimates of the actual reaction. A thermodynamic analysis of the five component system Li-Be-C1-O-F was completed as follows. Fig. 13 shows the three quaternary subsystems of interest. Based on reactions in Table 6 , the ternary phase compatibilities in Fig. 14 have been constructed. Based on these compatibilities and additional reactions in Table 6 , the schematic quaternary phase compatibilities in Fig. 15 have been derived; these show the results of progressive chlorination, fluorination, or oxygenation of LiBe fuel (Table 7 lists equilibrium reactions involving LiBe fuel with various combinations of $\mathrm{C} 1,0$ and F). Fig. 16 indicates calculated compatibilities among likely reaction products. The reaction postulated on the basis of thermodynamic data for complete oxidation of LiBe by PCF is:

$$
8 \mathrm{LiBe}+3 \mathrm{ClO}_{3} \mathrm{~F} \rightarrow 8 \mathrm{BeO}+\mathrm{Li}_{2} \mathrm{O}+3 \mathrm{LiF}+3 \mathrm{LiCl}
$$

The enthalpy relased by this reaction at $1100 \mathrm{~K}$ would be $4.6 \mathrm{kcal} / \mathrm{g}$. 


\section{B. Safety Considerations (7)}

Lithium and beryllium do not form stable intermetallic compounds together (10) and would be expected to be present together in fuel as the chemically uncombined metals. For a discussion of Li safety hazards, see $\mathrm{Li} / \mathrm{H}_{2} \mathrm{O}$ above. Beryllium is highly toxic both in metallic form and in compound form. Many of the beryllium salts have high vapor pressures, especially when heated. Symptoms of exposure usually involve respiratory distress of varying severity; symptoms may be delayed for several years after exposure. Chronic berylliosis can lead to death from respiratory and cardiac failure. In addition to harm incurred by inhalation, bery1lium and its compounds also act on the skin, causing lesions and tumors. Beryllium by itself does not present an explosion hazard, however the admixed lithium in the fuel obviously does. For a discussion of perchloryl fluoride safety refer to $\mathrm{LiAl} / \mathrm{ClO}_{3} \mathrm{~F}$ above.

VIII. Li/C ${ }_{11} \mathrm{~F}_{20}$

\section{A. Starting Materials}

The fluorocarbon compound $\mathrm{C}_{11} \mathrm{~F}_{20}$ was not obtainable from commercial suppliers; the closest molecular weight compound available was the structurally similar double ring compound $\mathrm{C}_{11} \mathrm{~F}_{19}$, an apparently stable, clear liquid. Experiments have not yet been completed due to the necessity of installing a special furnace with a boiling chamber for the liquid oxidant on the thermoanalyzer. It is hoped that loan from another facility of a water vapor furnace (which would also provide 1 atm of $\mathrm{P}_{\mathrm{H}_{2} \mathrm{O}}$ for the $\mathrm{Li} / \mathrm{H}_{2} \mathrm{O}$ and $\mathrm{MgAl} / \mathrm{H}_{2} \mathrm{O}$ experiments) will provide a solution to this experimental problem. 


\section{B. Enthalpy}

In the absence of experimental data, it is again necessary to utilize thermodynamic estimates in arriving at an oxidation reaction for the enthalpy calculation. The system Li-F-C provides a compositional representation of the $\mathrm{Li} / \mathrm{C}_{11} \mathrm{~F}_{20}$ reaction. By using calculated reactions in Table 8, Fig. 17 can be constructed, showing schematic phase compatibilities at $1100 \mathrm{~K}$. On this basis, the thermodynamically estimated oxidation reaction is:

$$
\mathrm{C}_{11} \mathrm{~F}_{20}+20 \mathrm{Li} \rightarrow 11 \mathrm{C}+20 \mathrm{LiF}
$$

As no enthalpy data have been located for $C_{11} F_{20}$, it is necessary to make an estimate. This can be done by extending the procedures used for estimating properties of hydrocarbon molecules. A very approximate value of $900 \mathrm{kcal} / \mathrm{mole}$ is obtained in this way for $298 \mathrm{~K}$. The calculated enthalpy yield at $298 \mathrm{~K}$ is $3.1 \mathrm{kca} / \mathrm{g}$. Presumably the value at $1100 \mathrm{~K}$ would be somewhat higher.

\section{Safety Considerations (7)}

For a discussion of $\mathrm{Li}$ safety hazards, see $\mathrm{Li} / \mathrm{H}_{2} \mathrm{O}$ above. Data are not available for the $\mathrm{C}_{11} \mathrm{~F}_{19}$ obtained, but the related compound $\mathrm{C}_{11} \mathrm{~F}_{20}$ is a highly stable molecule which has been used to develop a synthetic blood substitute.

IX. $\mathrm{LiB} / \mathrm{NF}_{3}$

\section{A. Starting Materials}

$\mathrm{NF}_{3}$ has been obtained from a commercial source in small cylinders. 
Principal impurities are stated by the vendor as $\mathrm{N}_{2}, \mathrm{HF}$, NO and $\mathrm{H}_{2} \mathrm{O}$. A source of LiB has been located but the material has not yet been procured, and so there are not experimental data on the reaction at this point in time.

\section{B. Enthalpy}

In the absence of experimental data on the $\mathrm{LiB} / \mathrm{NF}_{3}$ reaction, thermodynamic analysis of the system Li-B-N-F (Fig. 18) is essential. Using the reactions in Table 9, the schematic $1100 \mathrm{~K}$ ternary phase relations in Fig. 19 have been calculated. Fig. 20 gives calculated compatibilities among product phases at $1100 \mathrm{~K}$. Table 10 gives reactions for progressive degrees of oxidation of LiB fuel by $\mathrm{NF}_{3}$. The suggested reaction for complete oxidation of LiB by $\mathrm{NF}_{3}$ is :

$$
3 \mathrm{LiB}+2 \mathrm{NF}_{3} \rightarrow 3 \mathrm{LiF}+\mathrm{BN}
$$

Boron trifluoride $\left(\mathrm{BF}_{3}\right)$ is a gas even at relatively low temperatures, and so this would not be a desirable reaction. However by simply adding excess lithium to the fuel, in principle the following reaction could be obtained:

$$
2 \mathrm{Li}+\mathrm{LiB}+\mathrm{NF}_{3} \rightarrow 3 \mathrm{LiF}+\mathrm{BN}
$$

Depending upon the kinetics, $\mathrm{BF}_{3}$ might still form as an intermediate product, but the equilibrium final partial pressure would be very low. Although LiB is known as a stable compound, thermochemical data were not available. It has been assumed that at $1100 \mathrm{~K}$ it would be molten, and the ideal solution approximation has been applied to give an enthalpy of formation of $0.0 \mathrm{kcal}$. The enthalpy yield of reaction [180] can then be calculated as $4.6 \mathrm{kcal} / \mathrm{g}$.

\section{Safety Considerations (7)}


have not found their way into appropriate compendiums, but it is reasonable to assume that the comments made above under discussion of safety for Li and LiAl fuels would also apply here. The compound is used in pyrotechnical devices, and so there may be a potential explosion hazard. With regard to $\mathrm{NF}_{3}$, it is a colorless gas with a moldy odor and a high toxicity similar to HF. It could therefore be expected to be extremely corrosive to the respiratory tract and skin. Prolonged exposure may cause skeletal changes.

X. Summary and Discussion

In terms of energy release/unit mass, ranking of various stored energy reactions is as in Table 11, which includes for reference, two schemes not otherwise discussed in this report:

$$
\begin{aligned}
& \mathrm{Mg}+\mathrm{H}_{2} \mathrm{O} \rightarrow \mathrm{MgO}+\mathrm{H}_{2} \\
& \mathrm{H}_{2}+(1 / 2) \mathrm{O}_{2} \rightarrow \mathrm{H}_{2} \mathrm{O} \\
& 2 \mathrm{Al}+3 \mathrm{H}_{2} \mathrm{O} \rightarrow \mathrm{Al}_{2} \mathrm{O}_{3}+3 \mathrm{H}_{2} \\
& 3 \mathrm{H}_{2}+(3 / 2) \mathrm{O}_{2} \rightarrow 3 \mathrm{H}_{2} \mathrm{O}
\end{aligned}
$$

Several points should be made regarding the ranking in Table 11. First, direct experimental evidence for several of these reactions has not yet been obtained, due in part to materials limitations. Although we are optimistic that these will soon be overcome, in the meantime the ranking 

in Table 11 may have only limited practical significance. An example is the reaction $\mathrm{Li} / \mathrm{H}_{2} \mathrm{O}[14]$. Theoretically it should be high on the list at $4.8 \mathrm{kcal} / \mathrm{g}$. However in practice this yield may not be achieved due to formation of $\mathrm{LiOH}$, which irreversibly ties up hydrogen in the water cycle, and reaction [13], with an enthalpy yield of 3.5 could prevail instead. Also there are presumably other factors such as safety to be considered. The high toxicity of beryllium makes the practicality of utilizing reaction [169] questionable. On the other hand, it could probably be said that since fuel or oxidant or both are inherently chemically unstable, all of the reaction schemes involve some degree of toxicity to human tissue or other safety hazards, and suitable safeguards must be employed with any reaction scheme to eliminate the possibility of containment failure or runaway reaction. For example, lithium metal exposed to moist air at room temperature rapidly generates hydrogen. Perchloryl fluoride has a toxic effect similar to $\mathrm{CO} . \mathrm{NF}_{3}$ is not only toxic but extremely hazardous under pressure. When all such factors are considered, undoubtedly the $\mathrm{Mg} / \mathrm{H}_{2} \mathrm{O}, \mathrm{MgAl} / \mathrm{H}_{2} \mathrm{O}$ and $\mathrm{Al} / \mathrm{H}_{2} \mathrm{O}$ schemes pose the least safety hazard; however the latter two fuels may require very high temperature operation to overcome the kinetic barriers to oxidation of the aluminum. In terms of safety the $\mathrm{LiAl} / \mathrm{H}_{2} \mathrm{O}$ scheme is also high on the list, as LiAl is much less reactive than lithium upon exposure to air. Furthermore from a practical viewpoint, there may be other factors to consider besides enthalpy yield. For example, although the $\mathrm{Li} / \mathrm{C}_{11} \mathrm{~F}_{20}$ and $\mathrm{Li} / \mathrm{H}_{2} \mathrm{O} ; \mathrm{NaO}_{2} / \mathrm{H}_{2} \mathrm{O}$ schemes rank low in Table 11 , there may be certain advantages associated with not having to store gaseous oxidizers.

Additional experimental work is necessary at higher temperatures than attained to date in order to verify the reactions presented in 
Table 11. Evidence to date suggests several of the reactions are kinetically hindered at temperatures below $650{ }^{\circ} \mathrm{C}$. We are optimistic that the materials limitations encoutered in this preliminary study will be overcome, so that relevant experimental data on high temperature kinetics and phase equilibria can be systematically gathered in the near future.

\section{Future Work}

The highest priority involves finding suitable container materials so that thermogravimetric experiments can be extended to higher temperatures. Rod stock of high density $\mathrm{MgO}$ has been obtained and is being fabricated into crucibles. Also beryllia crucibles will be machined to order by a vendor equipped to do this safely. Crucibles of $\mathrm{LiAlO}_{2}$ have already been fabricated. We are optimistic that use of one or more of these materials will allow us to extend the temperature range of experimentation into the $650-1000{ }^{\circ} \mathrm{C}$ region.

After the container problem is solved the first priority will be to determine if the oxidation reactions can be made to go to completion, and if so what the minimum temperature is at which this will occur. Once optimum conditions for reaction are determined, an attempt will be made to measure enthalpy of reaction directly using DTA.

Simultaneously with these experiments phase equilibrium measurements will commence. The first experiments will involve heating the predicted end products of the reactions together in sealed capsules, quenching and examining to see if they really are in equilibrium as suggested by the thermodynamically calculated reaction. This will give important information on solubilities (both liquid and solid) as well. 
It is hoped that mass spectrometric measurement of species vapor pressures during these reactions can be completed using the NBS transpiration mass spectrometry system. This apparatus allows measurements of species at pressures up to $10 \mathrm{~atm}$, which would more closely simulate actual reactor conditions. Top priority would be given to the investigation of the $\mathrm{LiAl} / \mathrm{ClO}_{3} \mathrm{~F}$ and $\mathrm{LiAlMg} / \mathrm{ClO} \mathrm{F}_{3} \mathrm{~F}$ systems. Also, the $(\mathrm{Li}+\mathrm{LiB}) / \mathrm{NF}_{3}$ and $\mathrm{Li} / \mathrm{C}_{11} \mathrm{~F}_{20}$ systems might be amenable to investigation by this approach. 
XII. References Cited

1. SCEPS II. A New High-energy Undersea Propulsion System, Garrett Pneumatic Systems Division, Report No. 41-3675 (1982).

2. Cook, L. P., Plante, E. R., Roth, R. S., Hastie, J. W., Phase Equilibria of Stored Chemical Energy Reactants, National Bureau of Standards, Report No. NBSIR 84-2490, 112 p. (1984).

3. Costas, L. P. and Marsha11, R. P., Trans. Met. Soc. AIME, 224, 971 (1962).

4. Kalakutskaya, N. A., Tepl. Vys. Temp., 6 436 (1968).

5. Levine, E. D. and Rapperport, E. J., Trans. Met. Soc. AIME, 224, 1204 (1963).

6. Stu11, D. R. and Prophet, H., JANAF Thermochemical Tables, Second Ed.: U. S. Govt. Printing Office, Washington, DC, NSRDS-NBS 37, (1971). See also later supplements for 1971-1981 (J. PHys. Chem. Ref. Data).

7. Sax, N. I., Dangerous Properties of Industrial Materials (Sixth Ed.): New York, Van Nostrand, 3124 p. (1984).

8. Murray, J. L., Bull. Alloy Ph. Diag. 3 [1] 60 (1982).

9. McAlister, A. J., Bull. Alloy Ph. Diag. 3 [2] 177 (1982).

10. Moffatt, W., The Hand Book of Binary Phase Diagrams, Vo1. 1: Schenectady, $\overline{\mathrm{NY}}$ : General Electric Co. (1981 and updates).

11. Groff, E. G., Characteristics of a steadily operating metal combustor: Penn. State Univ., Ph. D. thesis, 156 p. (1976). 
XIII. Appendix: Results of Literature Survey

Following are bibliographic listings which have been selected from a computerized literature search of the Chemical Abstracts Data Base (1967-1984). References are not annotated, and low temperature as well as high temperature studies have been included. References are loosely grouped according to search categories that roughly correspond to the various alternate stored chemical energy reaction fuels and oxidants. 
A. Oxidation of Lithium metal, including kinetics and oxidation by water

Besson, J.and Pelloux, A., 1967, Oxidation kinetics of lithium by water vapor: C. R. Hebd. Seances Acad. Sci., Ser. C, V. 265, No. 15, p. 816-19.

Cooper, J. F.; Hosmer, P. K. and Homsy, R. V., 1978, The anodic behavior of lithium in aqueous lithium hydroxide solutions: J. Electrochem. Soc., V. 125, No. 1, p. 1-7.

Korovin, N. V. and Smirnov, S. E., 1982, Anodic oxidation of 1ithium in lithium hydroxide solutions. Structure of a lithium film: Elektrokhimiya, V. 18, No. 11, p. 1510-12.

Stone, H. E. N., 1972, Oxidation of metals in relation to the periodic classification: J. Mater. Sci., V. 7, No. 10, p. 1147-53.

Touzain, P., 1967, Kinetic study of the oxidation of alkali metals by dry oxygen: Commis. Energ. At. (Fr.). Rapp., No. CEA-R 3301, p. 1-93. 
B. Oxidation of aluminum metal, including kinetics and oxidation by water

Agarwala, V. K. and Fort, T. Jr., 1974, Work function changes during low pressure oxidation of aluminum at room temperature: Surf. Sci., V. 45 , No. 2 , p. 470-82.

Agarwala, V. K and Fort, T. Jr., 1976, Nature of the stable oxide layer formed on an aluminum surface by work function measurements: Surf. Sci., V. 54, No. 1, p. 60-70.

Akimov, A. G.; Rozenfel'd, I. L. and Dagurov, V. G., 1980, X-ray electron spectroscopy study of oxidation of aluminum in oxygen and water vapor: Zashch. Met., V. 16, No. 5, p. 573-6.

Andreev, L. A.; Gel'man, B. G. and Zhukhovitskii, A. A., 1974, Absorption of hydrogen by solid aluminum during high-temperature oxidation in water vapors: Fiz-Khim. Issled. Meta11. Protsessov, No. L., p. 9094.

Bachrach, R. Z.; Flodström, S. A.; Bauer, R. S.; Hastrom, S. B. M. and Chadi, D. J., 1978, Surface resonances and the oxidation of singlecrystal aluminum: J. Vac. Sci. Technol., V. 15, No. 2, p. 488-93.

Baker, B. R. and Balser, J. D., 1976, Formation of films on aluminum by reaction with water: Aluminum (Duesseldorf), V. 52, No. 3, p. 197-200.

Bakulin, E. A.; Balabanova, L. A.; Bredov, M. M. and Stepin, E. V., 1973, Characteristic electron energy losses during oxidation of aluminum films: Fiz. Tverd. Tela (Leningrad), V. 15, No. 4, p. 1266-7.

Barycka, I. and Hejduk, A., 1974, Anodic oxidation of aluminum in a d.c. oxygen discharge: $\operatorname{Pr}$. Nauk. Inst. Technol. Elektron. Politech. Wroclaw., V. 11, p. 53-64.

Beck, A. F.; Heine, M. A.; Caule, E. J. and Pryor, M. J., 1967, Kinetics of the oxidation of Al in oxygen at high temperature: Corros. Sci., V. 7 , No. 1, p. 1-22.

Benndorf, C.; Keller, G.; Seidel, H. and Thieme, F., 1977, High-resolution quartz oscillator microbalance and its application to the initial oxidation of aluminum: J. Vac. Sci. Technol., V. 14, No. 3, p. 819-21.

Benninghoven, A. and Mueller, A., 1972, Investigation of the surface oxidation of metals in the submonolayer and monolayer range with the static method of secondary ion mass spectrometry: Thin Solid Films, V. 12, No. 2, p. 439-42.

Bhavani, K. and Vaidyan, V. K., 1979, Asymptotic form of oxide growth for aluminum thin films: Natl. Acad. Sci. Lett. (India), V. 2, No. 12, p. 457-9. 
Section $\underline{B}$, continued

Bradshaw, A. M.; Hofmann, P. and Wyrobisch, W., 1977, The interaction of oxygen with aluminum (111): Surf. Sci., V. 68, p. 269-76.

Breakspere, R. J., 1970, High-temperature oxidation of aluminum in various gases: J. Appl. Chem., V. 20, No. 7. p. 208-12.

Bullett, D. W., 1980, The bonding of oxygen to aluminum(111): Surf. Sci., v. 93, No. 1, p. 213-22.

Cathcart, J. V.; Petersen, G. F. and Sparks, C. J., 1967, Oxidation rate and oxide structural defects: Surfaces Interfaces 1, Proc. Sagamore 13th Army Mater. Res. Conf., Oak Ridge National Laboratory, Oak Ridge, TN, (Burke, J. J., Ed.), p. 333-46.

Chang, C. C.; Fraser, D. B.; Grieco, M. J.; Sheng. T. T.; Haszko, S. E.; Kerwin, R. E.; Marcus, R. B. and Sinha, A. K., 1978, Aluminum oxidation in water: J. Electrochem. Soc., V. 125, No. 5, p. 787-92.

Cox, B.,.1974, Technique for studying the rate controlling processes during metal oxidation: Proc. 5th Int. Congr. Met. Corros., At. Energy Canada Ltd., Chalk River, Ont., (Sato, N., Ed.), p. 682-9.

Dickens, P. G.; Heckingbottom, R. and Linnett, J. W., 1969, Oxidation of metals and alloys. II. Oxidation of metals by atomic and molecular oxygen: Trans. Faraday Soc., V. 65, No. 8, p. 2235-47.

Dong, D., 1982, Anodic oxidation treatment of aluminum reactor vessel: Huagong Jixie, No. 4, p. 59-62.

Eberhardt, W. and Kunz, C., 1978, Oxidation of aluminum single crystal surfaces by exposure to oxygen and water: Surf. Sci., V. 75, No. 4, p. 709-20.

Elyutin, V. P.; Mitin, B. S.; Samoteikin, V. V., 1971, Effect of oxygen pressure on the oxidation of aluminum: Izv. Akad. Nauk SSSR, Metal, V. 3, No.

Faeber, W. and Braun, P., 1975, Investigations of the oxide formation on metals with the Auger electron spectroscopy: Mikrochim. Acta, Suppl., V. 6, p. 391-402.

Fehlner, F. P. and Mott, N. F., 1971, Low-temperature oxidation. Reply to discussion: Oxid. Metals, V. 3, No. 3, p. 275-7.

Flodström, S. A.; Bachrach, R. Z.; Bauer, R. S. and Hagstrom, S. B. M., 1977, Oxidation of aluminum single crystal faces: (100), (110), and (111): Proc. 7 th Int. Vac. Congr., Palo Alto Res. Cent., Xerox, Palo Alto, CA, (Dobrozemsky, R.; Ruedenauer, F. and Viehboeck, F. P., Eds.), V. 2 , p. 869-72. 
Section $\underline{B}$, continued

Flodström, S. A.; Martinson, C. W. B.; Kalkoffen, B. and Kunz, C., 1980, Oxygen interaction with clean aluminum and magnesium films investigated by synchrotron-radiation-induced photoemission: Mater. Sci. Eng., V. 42, No. 1, p. 31-7.

Fontijn, A.; Felder, W. and Houghton, J. J., 1973, Kinetics of aluminum atom oxidation: U. S. Nat. Tech. Inform. Serv., AD Rep., No. 776673/6GA, $34 \mathrm{p}$.

Fontijn, A.; Kurzius, S. C. and Houghton, J. J., 1972, Kinetics of metal atom oxidation reactions: U. S. Nat. Tech. Inform. Serv., AD Rep., No. 749380,56 p.

Fridrich, J., 1971, Use of a quartz crystal microbalance to study the oxidation of aluminum during vacuum deposition: Thin Solid Films, V. 7, No. $3 / 4$, p. 277-85.

Gerlach, J. and Weber, J., 1974, Rate of oxidation of aluminum in fused cryolite: Metall, V. 28, No. 3, p. 218-23.

Glukhov, V. I.; Fedoseev, V. A.; Grigorenko, I. N. and Kolpakova, T. I., 1979, Chemical reactions of aluminum with water: Fiz. Aerodispersn. Sistem, (Kiev), No. 19, p. 49-54.

Godard, H. P., 1967, Oxide film growth over five years on some aluminum sheet alloys in air of varying humidity at room temperature: J. Electrochem. Soc., V. 114, No. 4, p. 354-6.

Goral'nik, A. S., 1968, Kinetics of the anodic oxidation of aluminum and its alloys: Elektrokhimiya, V. 4, No. 9, p. 1108-10.

Gorbunov, V. V.; Khromov, V. G. and Shidlovskii, A. A., 1971, Oxidative activity of water vapor, carbon dioxide, and carbon monoxide toward magnesium and aluminum powders: Zh. Prikl. Khim. (Leningrad), V. 44, No. 4, p. 727-34.

Gray, T. J. and Pryor, J. M., 1969, Oxidation kinetics: Mater. Sci. Res., Coll. of Ceram., State Univ. of New York, Alfred, NY, (Gray, T. J., Ed.), V. 4 , p 446-60.

Gremyachkin, V. M.; Istratov, A. G. and Leipunskii, 0. I., 1974, Formation of condensed oxide particles during combustion of fine metal drops: $\mathrm{Zh}$. Prikl. Mekh. Tekh. Fiz., No. 4, p. 70-8.

Grimblot, J. and Eldridge, J. M., 1982, Oxidation of aluminum films: J. Electrochem. Soc., V. 129, No. 10, p. 2369-72.

Grinbergs, M., 1975, High-temperature oxidation of aluminum: Tezisy Dokl. - 4th Konf. Molodykh Nauchn. Rab. Inst. Neorg. Khim., Akad. Nauk Latv. SSR, Inst. Neorg. Khim., Riga, USSR, (Sokolov, Yu. N., Ed.), p. 24-5. 
Section $\underline{B}$, continued

Hagstrom, S. B. M.; Bachrach, R. Z.; Bauer, R. S. and Flodström, S. A., 1977, Oxidation of aluminum surfaces studied by synchrotron radiation photoelectron spectroscopy: Phys. Scr., V. 16, No. 5-6, p. 414-19.

Hayden, B. E.; Klemperer, D. F.; Allen, G. C. and Tucker, P. M., 1980, The early stages of oxidation of magnesium, aluminum and magnesium/ aluminum alloys: Vide, Couches Minces, V. 201, Supp1., Proc. 4th, Int. Conf. Solid Surf., V1, p. 453-7.

Hunt, G. L. and Ritchie, I. M., 1972, Effect of pressure changes on the oxidation rate of aluminum at 323-673 K: J. Chem. Soc., Faraday Trans. 1 , V. 68, Pt. 8, p. 1413-22.

Hunt, G. L. and Ritchie, I. M., 1972, Oxidation of aluminum by nitrous oxide at 323-683 K: J. Chem., Faraday Trans. 1, V. 68, Pt. 8, p. 1423-34.

Kame1, K. H. M.; Awad, S. A. and Kassab, A., 1979, Mechanism of electrochemical reactions at aluminum electrodes in sodium hydroxide solutions: J. Electroana1. Chem. Interfacial Electrochem., V. 99, No. 1, p. 121-5.

Khan, J. M. and Makowiecki, D. M., 1978, Investigation of room-temperature oxidation of aluminum thin films by scanning high-energy electron diffraction: Surf. Sci., V. 77, No. 1, p. L155-L161.

Kirk, C. T., Jr. and Hueer, E. E., Jr., 1968, Oxidation of aluminum films in low-pressure oxygen atmospheres: Surf. Sci., V. 9, No. 2, p. 217-45.

Kiselev, V. I. and Lepinskikh, B. M., 1974, Kinetics of oxidation of molten aluminum: Deposited Doc., VINITI 542-74, 12 .

Kiselev, V. I.; Lepinskikh, B. M. and Zhuchkov, V. I., 1974, Kinetics of liquid metal oxidation by oxygen from the gaseous phase: Tr. Inst. Meta1l., Akad. Nauk SSSR, Ura1. Nauchn. Tsentr., V. 28, p. 117-20.

Klei, H. E. and Stutzman, L. F., 1968, Effect of oxide thickness on the oxidation of aluminum films: Mater. Sci. Eng., V. 3, No. 2, p. 71-5.

Krakauer, H.; Posternak, M.; Freeman, A. J. and Koelling, D. D., 1981, Initial oxidation of the aluminum(001) surface: Self-consistent electronic structure of clean aluminum(001) and aluminum(001)-p(1 x 1)oxygen: Phys. Rev. B: Condens. Matter, V. 23, No. 8, p. 3859-76.

Krueger, W. H. and Pollack. S. R., 1972, Initial oxidation of aluminum thin films at room temperature: Surface Sci., V. 30, No. 2, p. 263-79.

Labunov, V. A.; Parkhutik, V. P. and Gavrilov, I. G., 1977, Kinetics of low temperature oxidation of metals in closed systems: Vestsi Akad. Navuk BSSR, Ser. Fiz.-Tekh. Navuk, No. 4, p. 37-40. 
Section $\underline{B}$, continued

Labunov, V. A.; Parkhutik, V. P. and Tkharev, E. E., 1978, Model of the low-temperature oxidation of metals: Zh. Fiz. Khim., V. 52, No. 5, p. $1168-71$.

Labunov, V. A.; Smirnov, A. G. and Kazantsev, A. P., 1976, Effect of conditions for carrying out plasma oxidation on the kinetics of oxide growth on aluminum: v sb., Nitevid. Kristally i Tonkie Plenki., Ch. 2, p. 487-93.

Leitenberger, H.; Liebgott, H.; Schmidt, H. J. and Wuellenweber, H., 1973, Hydrogen from methanol and steam (Patent): Germany offen. DE 2220617.

Lepinskikh, B. M. and Kiselev, V. I., 1974, Oxidation of liquid metals and alloys by oxygen from the gas phase: Izv. Akad. Nauk SSSR, Met., No. 5, p. 51-4.

Levina, R. A. and Oleinikov, G. N., 1983, Contact potential difference study of the oxidation of aluminum: Real. Struktura i Svoistva Tverd. Te1, Sverdlovsk, p. 23-8.

Lokenbach, A. K.; Strods, V.; Lepins, L.; Sulce, A.; Abrams, I. and Zaporina, N. A., 1981, Effect of the initial state of the surface on oxidation kinetics of highly dispersed aluminum powders: Latv. PSR Zinat. Akad. Vestis, Kim. Ser., No. 1, p. 50-8.

Lokenbaha, A.; Strods, V.; Zaporina, N. A.; Abeltina, A.; Stodere, M.; Lepins, L. and Abrams, I., 1983, Nonisothermal oxidation of highly dispersed aluminum powders: Latv. PSR Zinat. Akad. Vestis, Kim. Ser., No. 3 , p. 310-14.

Lokenbach, A. K.; Zaporina, N. A. and Lepins, L., 1981, Phase composition and structure of oxide films on particles of highly dispersed aluminum powders: Latv. PSR Zinat. Akad. Vestis, Kim. Ser., No. 1, p. 45-9.

Maksimenko, V. I. and Maksimenko, L. S., 1973, Kinetics of oxidation of aluminum and its alloys in the liquid state: Nov. Teor. Tekhnol.

Meta11. Protsessov, p. 16-20.

Meierhoefer, W. and Oswald, H. R., 1972, Reaction of aluminum with molecular oxygen and nitrogen at temperatures between 400 and $600 \mathrm{deg}$ : Therm. Anal., Proc. 3rd Int. Conf., Inorg. Chem. Inst., Univ. Zurich, Zurich, Switz., (Wiedemann, H. G., Ed.), V. 2, p. 409-21.

Michel, R.; Jourdan, C.; Castaldi, J. and Derrien, J., 1979, On the initial interaction of oxygen with the (111) and (100) aluminum surfaces: Surf. Sci., V. 84, No. 2, p. L509-L514.

Mitin, B. S. and Samoteikin, V. V., 1971, Oxidation of molten aluminum: Zh. Fiz. Khim., V. 45, No. 3, p. 730 . 
Section $\underline{B}$, continued

Moskovits, M., 1972, Kinetics of oxidation of molten aluminum in oxidant streams: Oxid. Metals, V. 5, No. 1, p. 1-9.

Murata, Y. and Ohtani, S., 1972, Measurement of the growth of oxide layers on metals by low-energy electron spectroscopy. Aluminum: J. Vac. Sci. Technol., v. 9, No. 2, p. 789-91.

Natanson, M. E., 1968, Spectral analysis of surface oxidation of different metals: Dopov. Akad. Nauk Ukr. RSR, Ser. B, V. 30, No. 11, P. 1019-21.

Nevskii, 0. I.; Volkov, V. I.; Grishina, E. P. and Rumyantsev, E. M., 1979, Effect of surface films on the mechanism of the anodic dissolution of aluminum: Progres. Elektrofiz. i Elektrokhim. Metody Obrab., Saratov, p. $17-21$.

Oblath, S. B. and Gole, J. L, 1980, On the continuum emissions observed upon oxidation of aluminum and its compounds: Combust. Flame, V. 37 , No. 3, p. 293-312.

Pitts, J. R.; Bischke, S. D.; Falconer, J. L and Czanderna, A. W., 1984, Oxide formation on aluminum in the presence of $\mathrm{keV}$ electrons and carbon dioxide: J. Vac. Sci. Technol., A, V. 2, No. 2, Pt. 2, p. 1000-3.

Pryor, M. J., 1971, Low-temperature oxidation. Discussion: Oxid. Metals, V. 3, No. 3, p. 271-3.

Radin, A. Ya., 1974, Oxidation of molten metals: Svoistva Rasplavl. Met., Tr. 16th Soveshch. Teor. Liteinykh Protsessov, USSR, (Gulyaev, B. B., Ed.), p. $116-22$.

Severdenko, V. P.; Labunov, V. A. and Stel'makh, V. T., 1971, Kinetics of aluminum film oxidation in oxygen plasma: Khim.-Term. Obrab. Metal. Splavov, p. $154-6$.

Shinohara, K.; Kyogoku, H.; Kumada, K. and Seo, T., 1980, Oxidation kinetics of aluminum single crystals in a transmission electron misroscope: Ehime Daigaku Kiyo, Shizen Kagaku, B, V. 9, No. 3, p. 781-90.

Sinaiskii, N. A., 1971, Plasma-chemical process for preparing gamma-alumina: Nizkotemp. Plazma Tekhnol. Neorg. Veshchestv, Tr, 2nd Vses. Semin., USSR, (Zhukov, M. F., Ed.).

Stolyarov, E. A., 1968, Oxidation of aluminum with water by the action of ultrasound: Zh. Prikl. Khim. (Leningrad), V. 41, No. 10, p. 2302-3.

Stone, H. E. N., 1972, Oxidation of metals in relation to the periodic classification: J. Mater. Sci., V. 7, No. 10, p. 1147-53. 


\section{Section $\underline{B}$, continued}

Szalkowski, F. J., 1982, Evidence for a molecular intermediate during the oxldation of aluminum by water: J. Chem. Phys., V. 77, No. 10, p. 5224-7.

Szczeklik, J. and Schabowska, E., 1980, Kinetics of the formation of thin films of aluminum oxide in a low temperature plasma: Thin Solid Films, V. 71 , No. 1, p. L17-L19.

Vernidub, I. I.; Makolkin, I. A.; Gusev, N. I. and Abramov, Yu. A., 1968, Thermodynamic characteristics of the oxidation of aluminum and magnesium by water and water vapor: Tr., Mosk. Inst. Nar. Khoz., No. 46, p. 18-23.

Wah1, G., 1983, Coating composition and the formation of protective oxide layers at high temperatures: Thin Solid Films, V. 107, No. 4, P. 417-26.

Wiedmer, E. and Grauer, R., 1974, Behavior of aluminum electrodes in fluoride solutions: Aluminum (Duesseldorf), V. 50, No. 4, p. 268-70.

Yu, H. L.; Munoz, M. C. and Soria,. F., 1980, On the initial stages of oxidation of aluminum (111) by LEED analysis: Surf. Sci., V. 94, No. 2-3, p. L184-L190.

Zhuravlev, V. A. and Zakharov, A. P., 1980, Oxidation of aluminum in water at different temperatures: Dok1. Akad. Nauk SSSR, V. 252, No. 5, p. 1162-6.

Zhuravlev, V. A. and Zakharov, A. P., 1980, Induction period at the initial stages of aluminum oxidation in water: Dok1. Akad. Nauk SSSR, V. 254, No. 5, p. 1155-8. 
C. Reaction of LiAl alloy with water

Ichik1, M. and Ishii, M., 1973, Electrolytic purification of waste water (Patent): Germany offen. DE 2225701.

Kanin, E. N.; Gustareva, A. A. ; Brazhnikova, G. I. and Zhukova, V. P., 1978, Anodic oxidation of an aluminum-magnesium-lithium alloy: Zashchita ot Korrozii Konstruktsion. Splavov., Kuibyshev, p. 84-90.

Oda, N.; Yoshida, T.; Nakanishi, T.; Yoshikawa, K.; Adachi, A.; Ueda, J. and Mizota, A., 1974, Production of high pressure gas (Patent): Japan Kokai Tokkyo Koho JP 7447282 .

Oda, T.; Yoshida, T.; Nakanishi, T.; Yoshikawa, K.; Adachi, A.; Ueda, S. and Mizota, A., 1977, Generation of a high-pressure gas propellant for self-propelled underwater vessels (Patent): Japan Tokkyo Koho JP 7727626.

Urbach, H. B.; Icenhower, D. E.; Cervi, M. C. and Bowen, R. J., 1974, Fuel cell using lithium-aluminum alloy anode and aqueous electrolyte (Patent): United States US 482980. 


\section{Oxidation of LiAl alloy}

Carpio, R. A. and King, L. A., 1981, Deposition and dissolution of lithiumaluminum alloy and aluminum from chloride-saturated lithium chloride-aluminum chloride and sodium chloride-aluminum chloride melts: J. Electrochem. Soc., V. 128, No. 7, p. 1510-17.

Field, D. J.; Butler, E. P. and Scamans, G. M., 1981, High-temperature oxidation studies of aluminum-3 wt. \% lithium, aluminum- 4.2 wt. \% magnesium and aluminum-3 wt. \% lithium-2 wt. \% magnesium alloys: Alum.-Lithium Alloys, Proc. Ist Int. Alum.-Lithium Conf., Dep. Metall. Mater. Sci., Imp. Coll., London, Eng1., (Starke, E. A., Jr., Ed.), p. 325-46.

Fridlyander, I. N.; Litvintsev, A. I.; Gabidullin, R. M.; Dudkina, S. I.; Klimova, L. N. and Shiryaeva, N. V., 1968, Oxidation of alloys of an aluminum-magnesium-lithium system with a beryllium additive: Alyum. Splavy, V. 5, p. 335-41.

Fridlyander, I. N.; Sandler, V. S.; Nikol'skaya, T. I.; Savinkov, R. A. and Roshchina, I. N., 1978, Study of the near-surface layer of the aluminum alloy 01420: Izv. Akad. Nauk SSSR, Met., No. 2, p. 220-2.

Goncharov, V. I. and Breslavets, V. P., 1979, Mechanism of lithium-aluminum electrode performance: Fiz. Khim. Elektrokhim. Rasplavl. Tverd. Elektrolitov, Tezisy Dokl. Vses. 7 th Konf. Fiz. Khim. Ionnykh Rasplavov Tverd. Elektrolitov, USSR, V. 2, p. 125-7.

Horski, J., 1970, Method for obtaining tritiated water from a lithium-aluminum alloy irradiated in a reactor: Nov. Metody Poluch. Radioaktiv. Prep., Sb. Dokl. Simp., Cent. Prod. Distrib. Isot., Inst. Nucl. Res., Swierk, Pol., p. $311-18$.

Kanin, E. N.; Gustareva, A. A.; Brazhnikova, G. I. and Zhukova, V. P., 1978, Anodic oxidation of an aluminum-magnesium-lithium alloy: Zashchita ot Korrozii Konstruktsion. Splavov., Kuibyshev, p. 84-90.

Kuz'michev, L. V.; Maizlin, L. Ya.; Radin, A. Ya. and Gureev, B. D., 1976, Oxidation of aluminum-lithium alloys and methods of protection: Tekhnol. Legkikh Splavov. Nauch.-tekhn. Byul. VILSa, No. 8, p. 18-22.

L'vov, A. L.; Gnilomedov, A. A. and Protasov, E. N., 1979, Anodic oxidation of lithium-aluminum alloys in fused chlorides: Elektrokhim. Ionnykh Rasplavov, Saratov. Gos. Univ., Saratov, USSR, (Delimarskii, Yu. K., Ed.), p. 135-9.

L'vov, A. L.; Gnilomedov, A. A. and Protasov, E. N., 1979, Electrochemical behavior of lithium-magnesium, lithium-magnesium-aluminum, and lithiumsilicon alloys in a lithium chloride-potassium chloride molten eutectic: Issled. v Obl. Khim. Istochnikov Toka, (Saratov), No. 6, p. 3-6.

L'vov, A. L; Gnilomedov, A. A.; Selemenev, A. P. and Protasov, E. N., 1975, Anodic dissolution of lithium-aluminum alloys in a lithium chloride-potasslum chloride melt: Elektrokhimiya, V. 11, No. 9, p. 1322-4. 
E. Oxidation of Magnesium metal, including kinetics and oxidation by water

Andreev, L. A.; Lunskii, M. Kh.; Gel'man, B. G. and Zhukhovitskii, A. A., 1973, Kinetics of exoelectron emission during the oxidation of magnesium: Zh. Fiz. Khim., V. 47, No. 4, p. 852-5.

Bellobono, I. R.; Mazza, F. and Cataldi, M. T., 1976, Spontaneous dissolution of metals in aqueous electrolytes. II. Kinetics of the reaction of magnesium and zinc with hydrochloric acid solutions: Gazz. Chim. Ital., V. 106, No. 3-6, p. 259-65.

Benninghoven, A. and Wiedmann, L., 1974, Investigation of surface reactions by the static method of secondary ion mass spectrometry. IV. Oxidation of magnesium, strontium, and barium in the monolayer range: Surface Sci., V. 40, No. 2 , p. 483-92.

Bloshenko, V. N.; Merzhanov, A. G. and Khaikin, B. I, 1976, Determination of the kinetic parameters of the high-temperature oxidation of magnesium: Fiz. Goreniya Vzryva, V. 12, No. 5, p. 682-8.

Cismaru, D. and Simon, Z., 1969, Kinetics of the formation of oxide layers on metals: Rev. Roum. Chim., V. 14, No., 7, p. 837-43.

Faeber, W. and Braun, P., 1975, Investigations of the oxide formation on metals with the Auger electron spectroscopy: Mikrochim. Acta, Supp1., V. 6, p. 391-402.

Felder, W., 1981, Kinetics of some metal atom and metal fluoride oxidation reactions relevant to Air Force technology development: AeroChem Res. Lab. Inc., Princeton, NJ, Report No. AEROCHEM-TP-411, AFOSR-TR-81-0599, 20 p.

Flodström, S. A.; Martinson, C. W. B.; Kalkoffen, G. and Kunz, C., 1980, Oxygen interaction with clean aluminum and magnesium films investigated by synchrotron-radiation-induced photoemission: Mater. Sci. Eng., V. 42, No. 1 , p. 31-7.

Frishberg, I. V. and Mikulinskii, A. S., 1966, Comparison of oxidizability of metallic powders prepared by condensation and mechanically: Tr. Inst. Meta11., Sverdlovsk, V. 11, p. 49-53.

Fuggle, J. C.; Watson, L. M.; Fabian, D. J. and Affrossman, S., 1975, X-ray photoelectron studies of the reaction of clean metals (magnesium, aluminum, chromium, manganese) with oxygen and water vapor: Surf. Sci., V. 49, No. 1, p. 61-76.

Gorbunov, V. V.; Khromov, V. G. and Shidlovski, A. A., 1971, Oxidative activity of water vapor, carbon dioxide, and carbon monoxide toward magnesium and aluminum powders: Zh. Prikl. Khim. (Leningrad), V. 44, No. 4, p. 727-34.

Glushkov, V. E. and Fedoseeva, N. V., 1966, Ignition of magnesium particles in steam: Fiz. Coreniya, I. I. Mechnikov Odessk. Gos. Univ., Odessa, USSR, p. $37-41$. 
Section E, continued

Grasselli, R. K. ; Suresh, D. D. and Hardman, H. F., 1976, Oxidation catalyst (Patent): Germany Offen. DE 2530959.

Hayashi, S. and Saito, H., 1972, Growth of fibrous magnesia via the vapor phase: Yogyo Kyokai Shi, V. 80, No. 8, p. 319-23.

Hayden, B. E.; Klemperer, D. F.; Allen, G. C. and Tucker, P. M., 1980, The early stages of oxidation of magnesium, aluminum and magnesium/aluminum alloys: Vide, Couches Minces, V. 201, Supp1., Proc. 4th Int. Conf. Solid Surf., V1, p. 453-7.

Hayden, B. E.; Schweizer, E.; Koetz, R. and Bradshaw, A. M., 1981, The early stages of oxidation of magnesium single crystal surfaces: Surf. Sci., V. 111, No. 1, p. 26-38.

Hodgson, A. and Machie, J. C., 1979, A shock-tube study of the kinetics of evaporation and oxidation of magnesium: Combust. Flame, V. 35, No. 3, p. 323-34.

Kashireninov, O. E. ; Kuznetsov, V. A. and Manelis, G. B., 1974, Kinetics of the gas-phase reaction of magnesium with oxygen: AIAA Pap., V. 74-145, 8 p.

Kashireninov, O. E.; Manelis, G. B. and Repka, L. F., 1982, Refinement of kinetic constants for the oxidation of alkaline earth metal vapors: Zh. Fiz. Khim., V. 56, No. 4, p. 1030-1.

Kashireninov, O. E. and Osherov, V. I., 1981, Polanyi-Semenov rule in gas-phase reactions of alkaline earth metals: Dokl. Akad. Nauk SSSR, V. 257, No. 3, p. $636-40$.

Koetz, R.; Hayden, B.; Schweizer, E. and Bradshaw, A. M., 1981, The application of spectroscopic ellipsometry to the oxidation of magnesium: Surf. Sci., V. 112 , No. 3, p. 229-40.

Kovalev, G. I.; Gogitidze, L. D.; Kuranova, V. I. and Denisov, E. T., 1979, Kinetics of the oxidation of fuels in the presence of structural materials: Neftekhimiya, V. 19, No. 2, p. 237-43.

Lea, C. and Molinari, C., 1984, Magnesium diffusion, surface segregation and oxidation in aluminum-magnesium alloys: J. Mater. Sci., V. 19, No. 7, p. $2336-52$.

Markstein, G. H., 1968, Study of the reaction of magnesium vapor and oxygen at the surface of magnesia deposits by atomic-absorption spectrophotometry: Purdue Univ., Lafayette, IN, U. S. Clearinghouse Fed. Sci. Tech. Inform., AD, No. $\mathrm{AD}-672575,34 \mathrm{p}$.

Namba, H.; Darville, J. and Gilles, J. M., 1980, Oxidation of single crystalline magnesium (0001) studied by ELS, AES, LEED and work function measurements: Vide, Couches Minces, V. 201, Supp1., Proc. 4th Int. Conf. Solid Surf., V1, p. 470-3. 
Section $\underline{E}$, continued

Namba, H.; Darville, J. and Gilles, J. M., 1981, A model for the oxidation of magnesium (0001) based upon LEED, AES, ELS and work function measurements: Surf. Sci., V. 108, No. 3, p. 446-82.

Natanson, M. E., 1968, Spectral analysis of surface oxidation of different metals: Dopov. Akad. Nauk Ukr. RSR, Ser. B, V. 30, No. 11, p. 1019-21.

Ponomarenko, A. M.; Bondarev, B. I. Ivanov, V. S., 1978, Kinetics of 1iquid magnesium oxidation in an atmosphere of air and argon with sulfur dioxide and sulfur hexafluoride additives: Tekhnol. Legk. Splavov, No. 8, p. 3-8.

Sarrazin, P. and Besson, J., 1966, Kinetics of magnesium oxidation by dry oxygen at 350-450 degrees. Pressure dependence: Metallurgie (Mons, Belg.), V. 6 , No. 1, p. 11-15.

Selivanov, S. E., 1971, Oxidation of magnesium in nitrous oxide: Fiz. Aerodispersnykh Sist., No. 4, p. 62-6.

Sergeev, G. B.; Smirnov, V. V.; Zagorskaya, 0. V.; Zagorskii, V. V. and Popov, A. V., 1982, Low-temperature reaction of magnesium atoms and carbon dioxide: Vestn. Mosk. Univ., Ser. 2: Khim., V. 23, No. 3, p. 232-6.

Shevtsov, V. I. and Fursov, V. P., 1983, Study of the mechanism of oxidation of magnesium: Fiz. Goreniya Vzryva, V. 19, No. 4, p. 99-102.

Stone, H. E. N., 1972, Oxidation of metals in relation to the periodic classification: J. Mater. Sci., V. 7, No. 10, p. 1147-53.

Svettsov, V. I. and Labirev, V. L., 1981, Calculation of process rates during the plasma reaction-thermal deposition of oxide films: USSR, Deposited Doc., Report No. SPSTL $61 \mathrm{khp-D81,} 21 \mathrm{p}$.

Tetere, A.; Steina, D.; Lokenbah, A.; Lepins, L. and Abrams, I., 1976, Oxidation of magnesium hydrosol: Latv. PSR Zinat. Akad. Vestis, Kim. Ser., No. 5, p. 564-8.

Tiunov, V. S.; Mamaev, V. I. and Morachevskil, A. G., 1979, Study of the electrochemical behavior of lithium-magnesium alloys in a lithium chloridepotassium chloride molten electrolyte: Fiz. Khim. Elektrokhim. Rasplavl. Tverd. Elektrolitov, Tezisy Dokl. Vses. 7th Konf. Fiz. Khim. Ionnykh Rasplavov Tverd. Elektrolitov, V. 2, 122 p.

Tseluikina, G. V. and Abakhaev, M. G., 1981, Electrochemical behavior of magnesium in liquid ammonia media: Khim. Istochniki Toka, Novocherkassk, p. 50-6.

Vale, R. and Smallman, R. E., 1977, An x-ray topographic study of the behavior of vacancy loops formed during the high-temperature oxidation of magnesium crystals: Philos. Mag., V. 36, No. 1, p. 209-23. 


\section{Section E, continued}

Vernidub, I. I.; Makolkin, I. A.; Busev, N. I. and Abramov, Yu. A., 1968, Thermodynamic characteristics of the oxidation of aluminum and magnesium by water and water vapor: Tr., Mosk. Inst. Nar. Khoz., No. 46, p. 18-22.

Williams, R. E. and Kottenstette, J. P., 1967, Approach to combustion kinetics new technique: West. States Sect., Combust. Inst. (Pap.), No. 67-27, 14 p. 
F. Oxidation of aluminum-magnesium alloy, including kinetics and oxidation by water

Anthony, W. H. and Rasmussen, T. S., 1976, Corrosion-resistant aluminum composite material (Patent): Germany offen. DE 2458201.

Baranov, N. S.; Lotsmanov, S. N.; Stepanov, G. A.; Getalov, S. P.; Red'kin, L. A.; Lokhmatov, B. V.; Egorov, V. M. and Shlyamneva, I. A., 1970, Alloy for dehydration of molten salts (Patent): USSR SU 270462.

Boehmer, M. and Munz, D., 1975, Fatigue of an aluminum-magnesium alloy ( $\mathrm{AlMg}_{3}$ ) in gases of different pressures. I. Fatigue life measurements: Z. Metallkd., V. 66 , No. 6 , p. 329-33.

Boehmer, M. and Munz, D., 1975, Fatigue of an aluminum-magnesium ( $\mathrm{AlMg}_{3}$ ) in gases of different pressures. II. Surface studies and fractography: Z. Meta11kd., V. 66, No. 6, p. 333-7.

Boehmer, M. and Munz, D., 1975, Fatigue of the aluminum alloy $\mathrm{AlMg}_{3}$ in gases of different pressures. III. Gas-metal interaction during fatigue: Z. Metallkd., v. 66 , No. 7 , p. 416-21.

Case, B.; Bradford, P. M. and Garbett, K., 1977, Silicate and the aqueous corrosion of a high-magnesium alloy: Nature (London), V. 268, No. 5617, p. 223-5.

Cherepakhova, G. L. and Shreider, A. V., 1972, Effect of the ions of cooling waters on the pitting corrosion of an aluminum-magnesium alloy: $\mathrm{Zh}$. Prik1. Khim. (Leningrad), V. 45, No. 9, p. 1958-63.

Cochran, C. N.; Belitskus, D. L. and Kinosz, D. L., 1976, Oxidation of aluminum-magnesium melts in air, oxygen, flue gas, and carbon dioxide: Light Met., Proc. Sess., AIME Ann. Meet., V. 2, p. 203-27.

Ford, F. P., 1972, Stress corrosion-resistant aluminum-magnesium alloy (Patent): Germany offen. DE 2114209.

Gavra, Z.; Hadari, Z. and Mintz, M. H., 1981, Effects of nickel and indium ternary additions on the hydrogenation of magnesium-aluminum intermetallic compounds: J. Inorg. Nuc1. Chem., V. 43, No. 8, p. 1763-8.

Gorbunov, V. V.; Vasil'ev, A. V. and Shidlovskii, A. A., 1959, Combustion of mixtures of high-energy metal powders with water: Izv. Vyssh. Ucheb. Zaved., Khim. Khim. Tekhnol., V. 12, No. 9, p. 1171-4.

Grauer, R. and Schmoker, P., 1976, The oxidation of aluminum-magnesium alloys in oxygen at elevated temperatures: Werkst. Korros., V. 27, No. 11, p. 769-74.

Haginoya, I. and Fukusako, T., 1984, Influence of water vapor on the oxidation of molten aluminum-magnesium alloys: Imono, V. 56, No. 5, p. 264-8. 
Section $\underline{F}$, continued

Hayden, B. E.; Klemperer, D. F.; Allen, G. C. and Tucker, P. M., 1980, The early stages of oxidation of magnesium, aluminum and magnesium/aluminum alloys: Vide, Couches Minces, V. 201, Suppl., Proc. 4th Int. Conf. Solid Surf., V1, p. 453-7.

Kovalenko, A. I., 1979, Electrochemical characteristics of anode alloys in stratal water: Korroz. Zashch. Neftegazov. Prom-sti., No. 7, p. 16-19.

Kuznetsov, D. A.; Notkin, E. B. and Malakhov, A. I., 1969, Effect of some factors on the quantity and chemical composition of evolving gases during sand mold casting of aluminum-magnesium alloys: Tr. Mosk. Khim.-Tekhnol. Inst., No. 60, p. 254-6.

Lepinskikh, B. M. and Belousov, A. A., 1975, Study of the kinetics of oxidation of magnesium-aluminum alloys in a molten state: Deposited Doc., VINITI 554-76, $12 \mathrm{p}$.

Maischak, K. D. and Feige, W., 1970, Causes and prevention of aluminum-water explosions: Neue Huette, V. 15, No. 11, p. 662-5.

Makovichuk, Yu. I. and Psarev, V. I., 1976, Agglomeration kinetics of betaphase particles in aluminum-magnesium alloys: Nekotor. Vopr. Fiz. Kinet. Tverd. Tel, No. 2, p. 35-63.

Mima, G. and Yamaguchi, M., 1964, Isothermal softening spectrum of cold drawn aluminum alloys with 2 weight \% magnesium. Optical microscopic observations and kinetics of isothermal softening: Nippon Kinzoku Gakkaishi, V. 28, p. $710-16$.

Mintz, M. H.; Malkiely, S.; Gavra, Z. and Hadari, Z., 1978, Effect of Group IIIA metal additives on the kinetics of magnesium hydride formation: J. Inorg. Nuc1. Chem., V. 40, No. 11, p. 1949-51.

Nair, C. G. K., 1983, Kinetics of magnesium loss during melting/holding of aluminum-magnesium alloys: Trans. Indian Inst. Met., V. 36, No. 4-5, p. 351-3.

Nikitina, M. F.; Fadeeva, G. N. and Romashin, V. M., 1966, Oxidation kinetics of aluminum-magnesium alloys: Tr., Mosk. Aviats. Tekhnol. Inst., No. 67, p. $65-78$.

Pagetti, J., 1972, New device for studying passivation of metals and alloys: AVIRES 2, Colloq. 2nd Int. App1. Sci. Tech. Vide Revetements Etats Surface, C. R., Lab. Genie Chim., Ec. Nat1. Super. Chim. Paris, Fr., p. 174-88.

Psarev, V. I. and Kulikov, A. F., 1977, Kinetics of the coalescence of disperse beta-phase of aluminum-magnesium alloys. I: Izv. Vyssh. Uchebn. Zaved., Fiz., v. 20, No. 12, p. 46-51.

Radin, A. Ya., 1974, Oxidation of molten metals: Svoistva Rasplav1. Met., 16rh Tr. Soveshch. Teor. Liteinykh Protsessov, USSR (Gulyaev, B. B., Ed.), p. 116-22. 
Section $F$, continued

Ryum, N. and Embury, J. D., 1982, A comment on the recrystallization behavior of aluminum-magnesium: Scand. J. Metall., V. 11, No. 2, p. 51-4.

Shimogori, K.; Fujiwara, K. and Komura, M., 1974, Corrosion-resistant aluminum alloy useful as heat exchanger tube material (Patent): Japan Kokai Tokkyo Koho JP 7458013.

Shrieder, A. V. and Cherepakhova, G. L., 1972, Reversal of polarity during the contact corrosion of aluminum-magnesium alloys: Zh. Prikl. Khim. (Leningrad), V. 45, No. 7, p. 1603-4.

Tuck, C. D. S. and Scamans, G. M., 1982, Hydrogen embrittlement of aluminumzinc-magnesium and aluminum-magnesium alloys: Hydrogene Mater., 3rd Congr. Int., Alcan Int. Ltd., Banbury, UK (Azou, P., Ed.), V. 2, p. 665-70. 
G. Lithium-beryllium alloys

Alekseevskii, N. E. and Zakosarenko, V. M., 1973, Superconductivity of beryllium alloys: Dokl. Akad Nauk SSSR, V. 208, No. 2, p. 303-6.

Fridlyander, I. N.; Gulin, A. N.; Sandler, V. S.; Yatsenko, K. P.; Kolesnikova, V. I.; Polyakov, E. S. and Yudin, A. F., 1971, Deformable alloy based on aluminum (Patent): USSR SU 310946.

Griffiths, L. B., 1969, Fine-grained, ductile beryllium-aluminum-magnesiumsilicon composites obtained by chill-mold casting under argon using lithium chloride and fluoride as flux (Patent): France FR 1567093, 9 p.

Krock, R. H.; Larsen, E. I. and Jones, C. R., 1967, Alloys of beryllium with aluminum magnesium (Patent): United States US 3323880, 5 p.

Krock, R. H.; Larsen, E. I. and Jones, C. R., 1967, Alloys of beryllium with silver and aluminum (Patent): United States US 3322512, 5 p.

Nishimura, M., 1971, Beryllium-containing metal filler for welding aluminum (Patent): Japan Tokkyo Koho JP 7139452, 2 p.

TRW Inc., 1968, Controlled heat production by the reaction of sulfur hexafluoride with lithium (Patent): France FR 1526940, 3 p.

Pauliukonis, R. S., 1967, Sulfur hexafluoride-lithium fuel (Patent): United States US 3325318,2 p. 
H. Lithium-boron alloys

Bischof, J.; Dlouhy, Z,; Kvitek, V. and Vobecky, M., 1972, Determination of boron and lithium in materials by an ( $n$, alpha) nuclear reaction: Jad. Energ., V. 18, No. 9, p. 269-8.

Born, E. and Loewedey, R., 1975, Diffusion of the products of the nuclear reaction $10 B(n, a l p h a) 7 L i$ and hydrogen in single crystals of betarhombohedral boron: Atomkernenergie, V. 26, No. 4, p. 283-4.

Born, E.; Krah1, J. and Loewedey, R., 1975, Distribution of 1ithium in surface layers of neutron irradiated boron crystals and its change following heat treatment: Atomkernenergie, V. 26, No. 1, p. 58-60.

Dallek, S., Ernst, D. W. and Larrick, B. F., 1979, Thermal analysis of lithium-boron alloys: J. Electrochem. Soc., V. 126, No. 5, p. 866-70.

Dallek, S.; Larrick, B. F. and Szwarc, R., 1982, Lithium-boron alloy anodes for thermally activated batteries: Proc. Power Sources Symp., V. 30, p. 42-5.

De Vries, R. C. and Fleischer, J. F., 1972, Cubic boron nitride preparation from lithium-boron-nitrogen mixtures (Patent): United States US 3701826.

DeVries, L. E. and Gubner, E., 1978, Determination of main components and impurities in lithium-boron alloys: Ana1. Chem., V. 50, No. 6, p. 694-8.

Dzhakhandarov, Sh. D.; Rza-Zade, P. F.; Samedov, F. R. and Eyubova, N. A., 1975, Phase diagram of the lithium oxide-boron oxide-cobalt(II) oxide $\left(\mathrm{Li}_{2} \mathrm{O} \cdot \mathrm{B}_{2} \mathrm{O}_{3}-\mathrm{CoO}\right)$ system: Azerb. Khim. Zh., No. 4, p. 116-18.

Ernst, D., 1982, DSC study of two reactions in the lithium-boron alloy system: J. Electrochem. Soc., V. 129, No. 7, p. 1513-15.

Ferguson, I. F.; Masters, D. R. and Turek, M., 1983, The Auger spectra of lithium metal and "oxidized 1ithium": Salwick/Preston, UK, North, Div. Rep. ND-R - U. K. At. Energy Auth., Report No. ND-R-463(S), 26 p.

Itoh, M.; Sato, S. and Yokokawa, T., 1976, E.m.f. measurements of molten mixtures of lithium oxide + ; sodium oxide + , and potassium oxide + boron oxide: J. Chem. Thermodyn., V. 8, No. 4, p. 339-52.

James, S. D., 1981, Comparison of anodic dischargability of lithium-boron alloy with pure lithium in lithium carbide (LiCl0)4-propylene carbonate: Naval Surface Weapons Cent., Silver Spring, MD, Report No. NSWC/TR-81-155, SBI-AD-F500015, 27 p.

James, S. D., 1982, Comparison of anodic dischargeability of lithium-boron alloy with pure lithium in lithium perchlorate-propylene carbonate:

J. Appl. Electrochem., V. 12, No. 3, p. 317-21. 
Section $\underline{H}$, continued

James, S. D. and De Vries, L. E., 1976, Structure and anodic discharge behavior of lithium-boron alloys in the lighium chloride-potassium chloride eutectic melt: J. Electrochem Soc., V. 123, No. 3, p. 321-7.

Kezuka, H. and Iwamura, K., 1982, Studies of thin films of lithium-boron alloys: Appl. Surf. Sci., V. 11-12, No. 1-3, p. 144-8.

Kilroy, W. P. and Angres, I., 1979, The extraction and determination of free lithium in lithium-boron alloys: J. Less-Comon Met., V. 63, No. 1, P. 123-8.

Larrick, B. F.; James, S. D. and Szwarc, R., 1978, Lithium-boron alloy a new battery anode material: Proc. - Power Sources Symp., V. 28th, p. 95-8.

Lewis, H. L, 1980, Exothermic IR source materials. Lithium-boron alloy materials: Nav. Weapons Support Cent., Crane, IN, Report No. NWSC/CR/RDTR-134, $18 \mathrm{p}$.

Lewis, H. L., 1982, Thermogravimetric analysis of reactivity of an air-reactive alloy of lithium and boron: Proc. Int. Pyrotech. Semin., V. 8, p. 446-65.

McManis, G. E.; Miles, M. H. and Fletcher, A. N., 1984, The lithium-boron alloy anode in molten nitrate electrolytes: J. Electrochem. Soc., V. 131, No. 2 , p. 286-9.

Mestwerdt, R. and Selzer, H., 1976, Experimental investigation of boron/lithium combustion: AIAA J., V. 14, No. 1, p. 100-2.

Mitchell, M. A. and Sutula, R. A., 1978, The density, electrical resistivity and Hall coefficient of lithium-boron alloys: J. Less-Common Met., V. 57 , No. 2, p. 161-75.

Nakamura, S. and Hayashi, H., 1975, Compounds in a lithium oxide-boron oxide-water system: Yogyo Kyokai Shi, V. 83, No. 1, p. 38-45.

Schleyer, P. v. R., 1983, Are lithium carbide (CLi6), lithium nitride (NLis), lithium oxide $\left(\mathrm{OLi}_{4}\right)$, etc., hypervalent?: New Horiz. Quantum Chem., Proc. 4 th Int. Congr. Quantum Chem.; Friedrich-Alexander-Univ. Erlangen-Nurnberg, Erlangen, Germany (Loewdin, P.-0. and Pullman, B., Ed.), p. 95-109.

Samedov, F. R.; Rzazade, P. F. and Abdullaev, G. K., 1970, The $\mathrm{Li}_{2} \mathrm{O}_{\cdot} \mathrm{B}_{2} \mathrm{O}_{3}-$ $\mathrm{Ga}_{2} \mathrm{O}_{3}$ system: Izv. Akad. Nauk SSSR, Neorg. Mater., V. 6, No. 5, P. 1030-1.

Secrist, D. R., 1967, Compound formation in the systems lithium-carbon and lithium boron: J. Am. Ceram. Soc., V. 50, No. 10, p. 520-3.

Selzer, H., 1975, Use of lithium boride $\left(\mathrm{LiB}_{2}\right)$ in pyrotechnic fires: Pyrotech.: Grundlagen, Technol. Anwend., Jahrestag., Inst. Chem. Treib-Explosivst. Fraunhofer-Ges., Bremen, Germany, p. 99-107. 
Section $\underline{\mathrm{H}}$, cont inued

Simons, D. G.; Land, D. J.; Brown, M. D. and Brennan, J. G., 1980, Ion Beam analysis of lithium-boron alloys: White Oak Lab., Nav. Surf. Weapons Cent., Silver Spring, MD, Report No. NSWC/TR-79-95, 18 p.

Sutula, R. A. and Wang, F. E., 1979, Battery with boron-lithium alloy anode (Patent): United States US 4162352.

Szwarc, R. and Dallek, S., 1982, Lithium-boron (Li(B)) ingot preparation scale-up study: Gen. Electr. Co., St. Petersburg, FL, Report No. GEPPTM-645, $44 \mathrm{p}$.

Szwarc, R.; Walton, R. D.; Dallek, S. and Larrick, B. F., 1982, Discharge characteristics of lithium-boron alloy anode in molten salt thermal cells: J. Electrochem. Soc., V. 129, No. 6, p. 1168-73.

Vakhtin, B. S. and Filippov, E. M., 1972, Differential determination of boron and lithium by the neutron-resonance method: Zh. Anal. Khim., V. 27, No. 3, p. 595-7.

Wang, F. E., 1978, Ductile 1ithium-boron alloys (Patent): United States US $4110111,4 \mathrm{p}$.

Wang, F. E., 1979, An unusual phenomenon in the formation of lithium-boron $\left(\mathrm{Li}_{5} \mathrm{~B}_{4}\right)$ compound-alloy: Metall. Trans., A, V. 10A, No. 3, p. 343-8. 


\section{Perchloryl fluoride and nitrogen trifluoride}

Adcock, W. and Khor, T. C., 1975, Perchloryl fluoride. Further warning: J. Organomet. Chem., V. 91, No. 1, p. C20.

Alekseev, V. I.; Fedorova, L. I. and Baluev, A. V., 1983, Mass-spectrometric study of thermochemical characteristics of perchloryl fluoride and its decomposition product chlorosyl fluoride: Izv. Akad. Nauk SSSR, Ser. Khim., No. 5, p. 1084-90.

Anderson, D. G.; England, D. C. and Milian, A. D., Jr., 1981, Fluorinated carbonyl compounds (Patent): Germany Offen. DE 3032471.

Aubert, J.; Bougon, R. and Carles, M., 1967, Hydrolysis of chlorine trifluoride, chlorine monofluoride, and chloryl fluoride. Study of the formation of perchloryl fluoride: Commis. Energ. At. (Fr.), Rapp., V. CEA-R $3282,19 \mathrm{p}$.

Barberi, P., 1973, Enthalpy of combustion and formation of oxychlorofluoride compounds: Bull. Inform. Sci. Tech., Commis. Energ. At. (Fr.), V. No. 180, p. 55-60.

Barberi, P., 1977, Contribution to the study of chlorine, fluorine and oxygen compounds: CEN Saclay, CEA, Gif-sur-Yvett, Fr., Report No. CEA-R-4771, 157 p.

Beardell, A. J. and Grelecki, C. J., 1968, Perchloryl fluoride (Patent): United States US 3404958.

Beresneva, I. V.; Mamynov, V. V. and Tukhvatullin, A. M., 1983, Logarithmic dependence of the heat capacity of individual substances on temperature: Zh. Fiz. Khim., V. 57, No. 2, p. 285-8.

Blackburn, G. M.; England, D. A. and Kolkmann, F., 1981, Monofluoro- and difluoromethylenebisphosphonic acids: isopolar analogs of pyrophosphoric acid: J. Chem. Soc., Chem. Commun., No. 17, p. 930-2.

Bougon, R.; Carles, M. and Aubert, J., 1967, Reaction between chlorine trifluoride and water: C. R. Hebd. Seances Acad. Sci., Ser. C, V. 265, No. 3, p. 179-82.

Britton, D.; Farooq, S. and Keese, R., 1977, Synthesis and structure of fluorotricyanomethane: Helv. Chim. Acta, V. 60, No. 4, p. 1393-7.

Cady, G. H., 1978, Solubility and reactions of perchloryl fluoride in water: J. Fluorine Chem., V. 11, No. 3-4, p. 225-41.

Cartwright, M. and Woolf, A. A., 1979, A redetermination of the heat of formation of perchloryl fluoride: J. Fluorine Chem., V. 13, No. 4, p. 353-64.

Christe, K. 0.; Curtis, E. C.; Sawodny, W.; Hartner, H. and Fogarasi, (i., 1981, The general valence force field of perchloryl fluoride: Spectrochim. Aclis, Part A, V. 37A, No. 7, p. 549-56. 
Section I, continued

Claassen, H. H. and Appelman, E. H., 1970, Vibrational spectra and structures of perbromyl and perchloryl fluorides: Inorg. Chem., V. 9, No. 3, p. 622-4.

Clark, A. H.; Beagley, B. and Cruickshank, D. W. J., 1968, Structural parameters of perchloryl fluoride and perchloric acid: Chem. Commun., No. 1, p. 14-15.

Clark, A. H.; Beagley, B.; Cruickshank, D. W. J. and Hewitt, T. G., 1970, Electron diffraction investigation of gaseous perchloryl fluoride and calculation of its force field and amplitudes of vibration: J. Chem. Soc. A, No. 6, p. 872-5.

Clark, R. J. H. and Rippon, D. M., 1974, Vapor phase Raman spectra, Raman band contour analyses, Coriolis constants, force constants, and thermodynamic functions of symmetric top molecules phosphoryl fluoride, phosphoryl chloride, trifluorooxovanadium, trichlorooxovanadium, thiophosphoryl chloride, and fluorine chlorate: Mol. Phys., V. 28, No. 2, p. 305-19.

DeLeon, R. L. and Muenter, J. S., 1980, Stark effect and dipole moment of perchloryl fluoride: J. Mol. Spectrosc., V. 83, No. 2, p. 469-70.

DeKock, R. L.; Lloyd, D. R.; Hillier, I. H. and Saunders, V. R., 1972, Experimental and theoretical study of the electronic structures of sulfuryl fluoride and perchloryl fluoride: Proc. Roy. Soc., Ser. A, V. 328, No. 1574, p. 401-11.

Dersch, R. and Reichardt, C., 1982, Syntheses with aliphatic dialdehydes. XXXIII. Attempts to synthesize difluoromalonaldhyde: Liebigs Ann. Chem., No. 7, p. 1330-47.

Dersch, R. and Reichardt, C., 1982, Syntheses with aliphatic dialdehydes. XXXIV. Attempts to synthesize bromo- or chlorofluoromalonaldehyde and fluoro(methy1) - or fluoro(pheny1)malonaldehyde: Liebigs Ann. Chem., No. 7 , p. 1348-58.

Farrar, T. C.; Maryott, A. A. and Malmberg, M. S., 1971, Pulsed NMR study of rotational diffusion in perchloryl fluoride: Ber. Bunsenges. Phys. Chem., V. 75 , No. $3 / 4$, p. 246-7.

Green, J.; Levine, N. B. and Sheehan, W., 1966, Elastomers resistant to rocket propellants: Rubber Chem. Technol., V. 39, No. 4, p. 1222-32.

Guest, M. F. and Hillier, I. H., 1972, Localized orbital calculations of the bonding in $\mathrm{SO}_{2}-4, \mathrm{SO}_{2} \mathrm{~F}_{2}, \mathrm{ClO}_{3} \mathrm{~F}$ and $\mathrm{SOCl}_{2}$ : Int. J. Quantum Chem., V. 6, No. 5, p. $967-73$.

Kamley, M. J., 1971, Explosive and/or propellant compounds containing a fluorodinitromethyl group (Patent): United States US 3624129. 


\section{Section I, continued}

Khutoretskii, V. M.; Okhlobystina, L. V. and Fainzil'berg, A. A., 1967 , Perchloryl fluoride (production, physical properties, reactions): Usp. Khim., V. 36, No. 3, p. 377-98.

Kliegel, J. R.; Gold, P. I. and Weekley, C. T., 1969, Chemical species and chemical reactions of importance in nonequilibrium rocket engine performance calculations: Pyrodynamics, v. 6, No. 3-4, p. 257-73.

Mohan, S.; Ravikumar, K. G.; Boopathy, T. J. and Chandraprakash, N., 1984, Normal coordinate analysis of some axially symmetric XYZ3 type molecules: Indian J. Phys., B, V. 58B, No. 1, p. 56-60.

Mountfield, K. R. and Weir, R. D., 1977, Low temperature heat capacity, dielectric constant, and thermodynamic properties of solid perchloryl fluoride: J. Chem. Phys., V. 66, No. 2, p. 736-42.

Nagarajan, G. and Redmon, M. J., 1972, Quantum mechanical studies of atomic, bond, and molecular polarizabilities, spectroscopic studies of vibrational constants, and statistical thermodynamics. Perchloryl and perbromyl fluorides: Monatsh. Chem., V. 103, No. 5, p. 1406-26.

Ostorero, J., 1970, Measurements of the viscosity of some gaseous fluorine compounds: Commis. Energ. At., Saclay, Fr., Report No. CEA-N-1293, 36 p.

Pilipovich. D.; Rogers, H. H. and Wilson, R. D., 1972, Chlorine trifluoride oxide. II. Photochemical synthesis: Inorg. Chem., V. 11, No. 9, p. 2192-5.

Ripmeester, J. A.; Garg, S. K. and Davidson, D. W., 1978, Molecular reorientation in solid perchloryl fluoride: J. Chem. Phys., V. 69, No. 5, p. 2265-7.

Rips, S. M.; Zercheninov, A. N. and Pankratov, A. V., 1969, Detection of the thermodynamic properties of some fluorine and chlorine compounds: Zh. Fiz. Khim., v. 43, No. 2, p. 386-9.

Rogers, H. H. and Pilipovich, D., 1973, Oxychlorine trifluoride (Patent): United States US 3718557.

Rosolovskii, V. Ya. and Nikitin. I. V., 1972, Nitrogen oxyfluorides. Chlorine oxyfluorides. (Collection of reviews): Inst. Nov. Khim. Probl., Chernogolovka, USSR, Report No. VINITI 5437-73, Deposited Publ., 70 p.

Rutt, H. N., 1980, Optically pumped laser action in perchloryl fluoride: Opt. Commun., V. 34, No. 3, p. 434-8.

Sheppard, W. A., 1969, Mechanism of fluorination by perchloryl fluoride: Tetrahedron Lett., No. 2, p. 83-4.

So, S. P. and Chau, F. T., 1973, Urey-Bradley force field of perhalyl fluorides: Z. Phys. Chem. (Frankfurt am Main), V. 85, No. 1-4, p. 69-75. 
Section I, continued

Streng, A. G., 1971, Miscibility and compatibility of some liquefied and solid$\mathrm{z}$ ified gases at low temperatures: J. Chem. Eng. Data, V. 16, No. 3, p. 357-9.

Sunder, S.; Hallin, K. E. and McClung, R. E. D., 1974, Raman studies of molecular reorientation in liquid perchloryl fluoride: J. Chem. Phys., v. 61, No. 7, p. 2920-4.

Sunder, S. and McClung, R. E. D., 1974, Raman spectra of polycrystalline perchloryl fluoride: Can. J. Phys., V. 52, No. 22, p. 2299-302.

Takano, K.; Hosoya, H. and Iwata, S., 1982, Analysis of the oxidation state and oxidation number by ab initio molecular orbital calculations: chlorine and sulfur compounds: J. Am. Chem. Soc., V. 104, No. 14, p. 3998-4005.

Tantot, G., 1976, Structural study of some halogen oxyfluorides: CEN Saclay, CEA, Gif-sur-Yvette, Fr., Report No. CEA-R-4770, 237 p.

Vereshchagin, A. N.; Vigalok, I. V.; Aliksandrova, L. K. and Petrova, G. G., 1981, Polarity and polarizability of some perchloryl compounds: Izv. Akad. Naul SSSR, Ser. Khim., No. 2, p. 257-61.

Vigalok, A. A.; Petrova, G. G.; Lukashina, S. G. and Vigalok, I. V., 1982, Study of the reaction of perchloryl fluoride with halide ions: $Z$ h. Neorg. Khim., v. 27, No. 8, p. 1931-4.

Vigalok, I. V.; Petrova, G. G. and Lukashina, S. G., 1983, Salts of the organic fluoronitrogen cation - 1-fluoro-1-alky1-2,2,6,6-te-tramethylz piperidinium: Zh. Org. Khim., v. 19, No. 6, p. 1347-8.

Wamser, C. A.; Fox, W. B.; Gould, D. and Sukornick, B., 1968, Preparation of perchloryl fluoride by acid solvolysis of perchlorates in fluorinated solvents: Inorg. Chem., V. 7, No. 9, p. 1933-5.

Wamser, C. A.; Sukornick, B. ; Fox, W. B. and Gould, D., 1973, Nontransitionz metal compounds. Perchloryl fluoride: Inorg. Syn., V. 14, p. 29-33.

Yodis, A. W. and Cunningham, W. J., 1968, Production of perchloryl fluoride (Patent): United States US 3375072.

Ziebell, G. and Gross, H., 1978, Aromatic perchloryl compounds (Patent): Patent No. Germany (East) DD 132391. 


\section{J. Fluorocarbon $\left(\mathrm{C}_{11} \mathrm{~F}_{20}\right)$}

Chambers, R. D.; Taylor, G. and Powe11, R. L, 1980, Reactions involving Fluoride ion. Part 18. Derivatives of perfluoro cycloalkenes: J. Chem. Soc., Perkin Trans. 1, No. 2, p. 429-34.

Clark, L. C., Jr.; Moore, R. E.; Diver, S. and Miller, M. L., 1979, A new look at the vapor pressure problem in red cell substitutes: Int. Congr. Ser. - Excerpta Med., V. 486, Proc. 4th Int. Symp. Perfluorochem. Blood Substitutes, 1978, p. 55-67.

Cottre11, D. W., 1970, Fluorocarbon dielectric coolants and their applications: Dielec. Mater., Meas. App1., Conf., Imp. Smelting Corp. Ltd., Avonmouth, Engl., p. 322-7.

Irving, J. B. and Jamieson, D. T., 1975, Thermal conductivity of 13 fluorocarbon liquids: J. Fluorine Chem., V. 5, No. 5, p. 449-56.

Lee, R.; Devotta, S. and Holland, F. A., 1984, Derived thermodynamic design data for Rankine power cycle systems operating on PP9: J. Heat Recovery Syst., V. 4, No. 1, p. 51-6.

Moore, R. E.; Clark, L. C., Jr. and Miller, M. L., 1979, Synthesis and biological activity of perfluoroadamantane and some closely related compounds: Int. Congr. Ser. - Excerpta Med., V. 486, Proc. 4th Int. Symp. Perfluorochem. Blood Substitutes, 1978, p. 69-79.

Morini, A.; Macchi, E. and Giglioli, G., 1980, Experimental results on the thermal stability of some fluorocarbons: Proc. Intersoc. Energy Convers. Eng. Conf., V. 15, No. 2, p. 992-7.

Nakamura, Y.; Umemura, H. and Yonekura, M., 1975, Emulsions of fluorinecontaining compounds (Patent): Japan Kokai Tokkyo Koho JP 75121184.

Nelson, J. K. and Manterfield, R. J., 1977, Sparking potentials in fluorocarbons vapors: Proc. Inst. Electr. Eng., V. 124, No. 6, p. 586-8.

Suntech, Inc., 1980, Determination of critical solution temperatures of perfluorocarbons (Patent): Japan'Kokai Tokkyo Koho JP 8095868.

Wesseler, E. P.; Iltis, R. and Clark, L. C., Jr., 1977, The solubility of oxygen in highly fluorinated liquids: J. Fluorine Chem., V. 9, No. 2, p. $137-46$.

Yokoyama, K.; Naito, R.; Tsuda, Y.; Fukaya, C.; Watanabe, M.; Hanada, S. and Suyama, T., 1983, Selection of 53 PFC substances for better stability of emulsion and improved artificial blood substitutes: Prog. Clin. Biol. Res., V. 122, Adv. Blood Substitute Research, p. 189-96. 
Section $\mathrm{J}$, continued

Yokoyama, K.; Suyama, T.; Okamoto, H.; Watanabe, M.; Ohyanagi, H. and Saitoh, Y., 1984, A perfluorochemical emulsion as an oxygen carrier: Artif, Organs, V. 8, No. 1, p. 34-40.

Yokoyama, K.; Yamanouchi, K.; Murashima, R. and Tsuda, Y., 1976, Oxygentransferable fluorocarbon emulsion (Patent): United States US 654964.

Yonekura, M.; Nagase, S.; Baba, H.; Kodaira, K. and Abe, T., 1976, The electrochemical fluorination of trifluoromethyl-substituted benzenes: Bull. Chem. Soc. Jpn., V. 49, No. 4, p. 1113-16. 
$-63-$

XIV. Tables 
Table 1. X-ray Diffraction Analysis of $\mathrm{LiAl} / \mathrm{ClO}_{3} \mathrm{~F}$ Experimental Products

Expt.

Max Temp.

\%t. Gain

Phases

TGA

$650{ }^{\circ} \mathrm{C}$
(isothermal)

109.86

$\alpha-\mathrm{Li}_{3} \mathrm{AlF}_{6}, \mathrm{LiF} * \mathrm{AlF}_{3}, \mathrm{~A} 1$

TGA

$550{ }^{\circ} \mathrm{C}$

97.58

$\mathrm{Al}, \mathrm{B}-\mathrm{Li}_{3} \mathrm{AlF}_{6}, \mathrm{AlF}_{3}, \mathrm{LiF}$

(is othermal)

TGA

$450{ }^{\circ} \mathrm{C}$

98.52

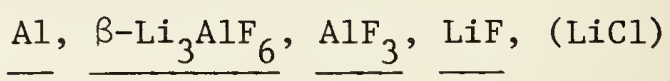

(isothermal)

TGA

$350{ }^{\circ} \mathrm{C}$

109.26

$\mathrm{A1}, \mathrm{AlF}_{3}, \mathrm{Li}_{3} \mathrm{AlF}_{6}$,

(is othermal)

Mass Spec.

$900{ }^{\circ} \mathrm{C}$

$---$

$\underline{\mathrm{LiAlO}_{2}}, \mathrm{A1}$

(non-isotherma1)

TGA

$650{ }^{\circ} \mathrm{C}$
(non-isothermal)

91.69

$\alpha \mathrm{Li}_{3} \mathrm{AlF}_{6}, \mathrm{AlF}_{3}, \mathrm{Al}, \mathrm{LiF}$

TGA

$650{ }^{\circ} \mathrm{C}$

50.43

LiC1, A1, LiA1, $\gamma_{\mathrm{LiAlO}}$, LiF

Partial React.

(is othermal)

*LiF apparently contains a small amount LiCl in solid solution, as judged by $\mathrm{x}$-ray line shifts 


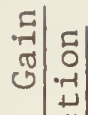

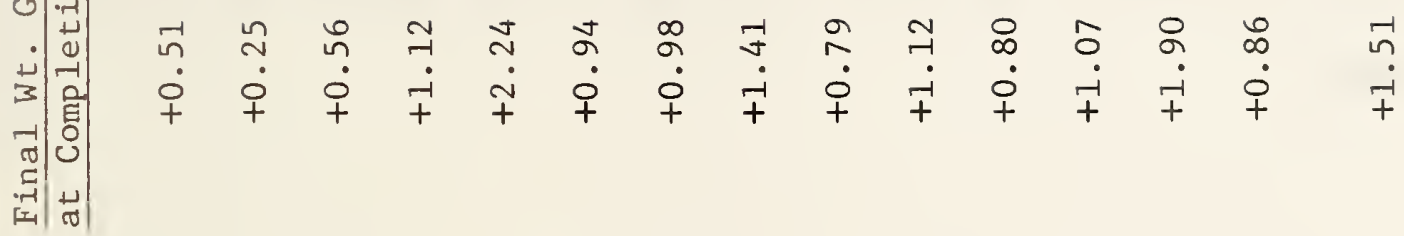

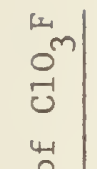

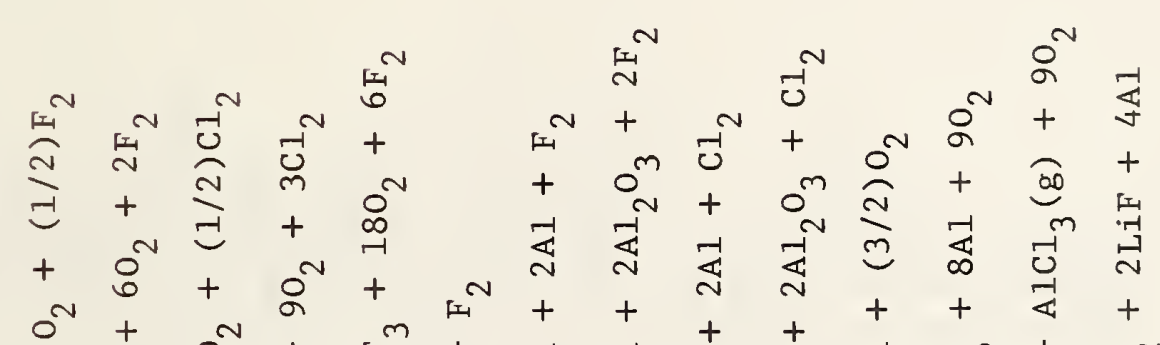

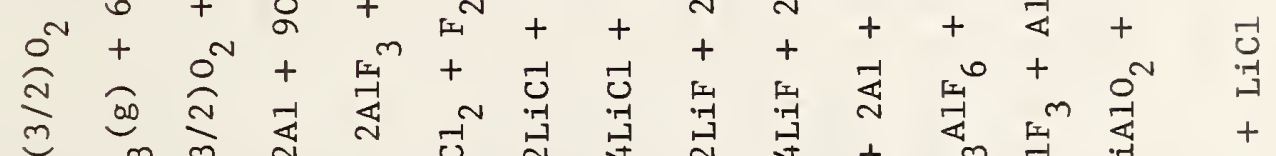
品
m

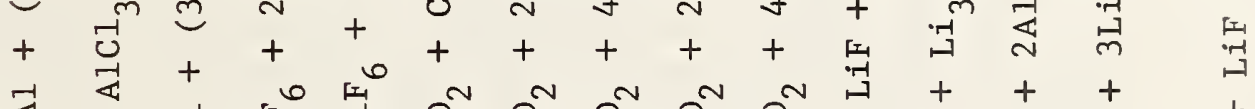
西

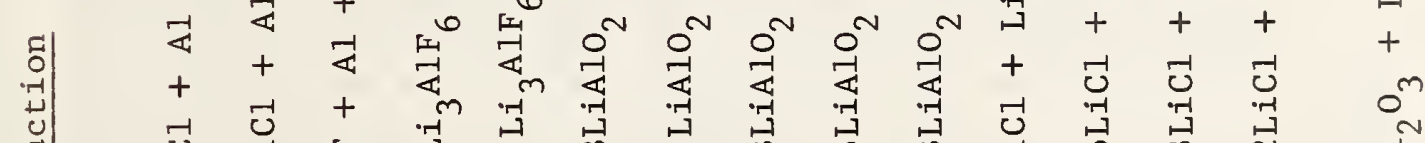

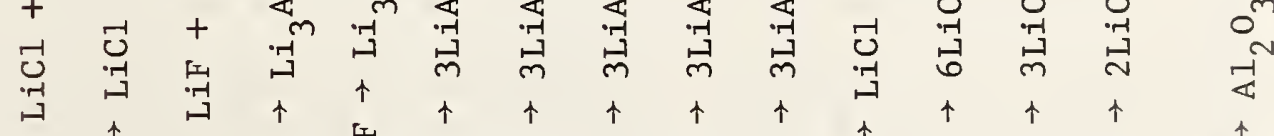

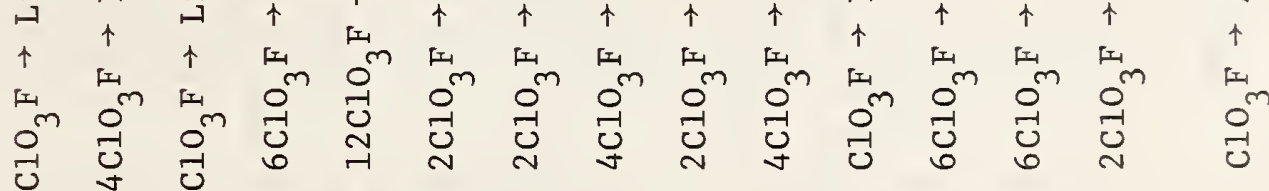

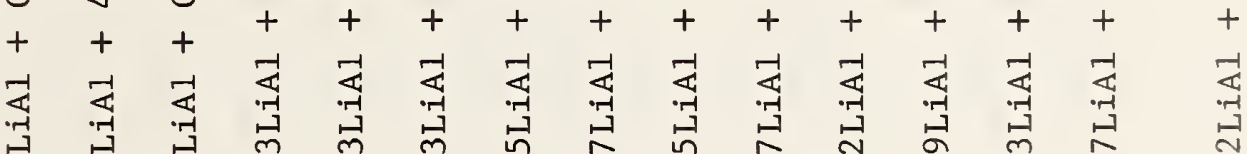

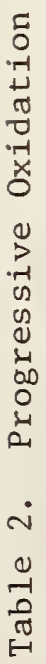

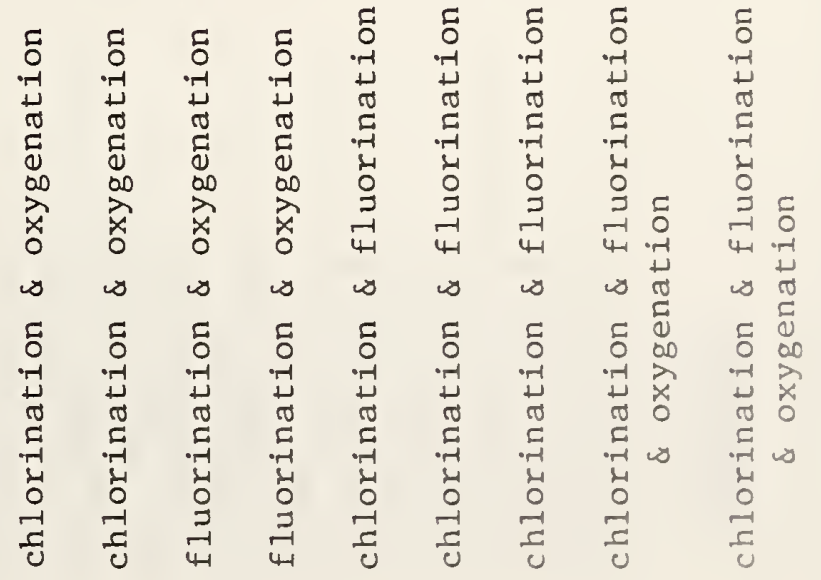




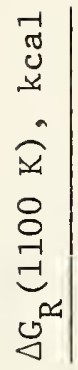

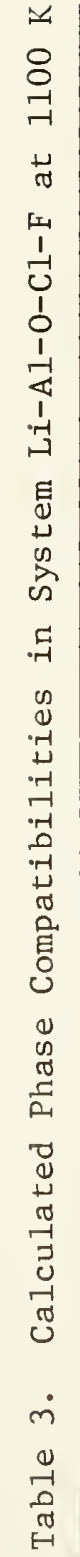

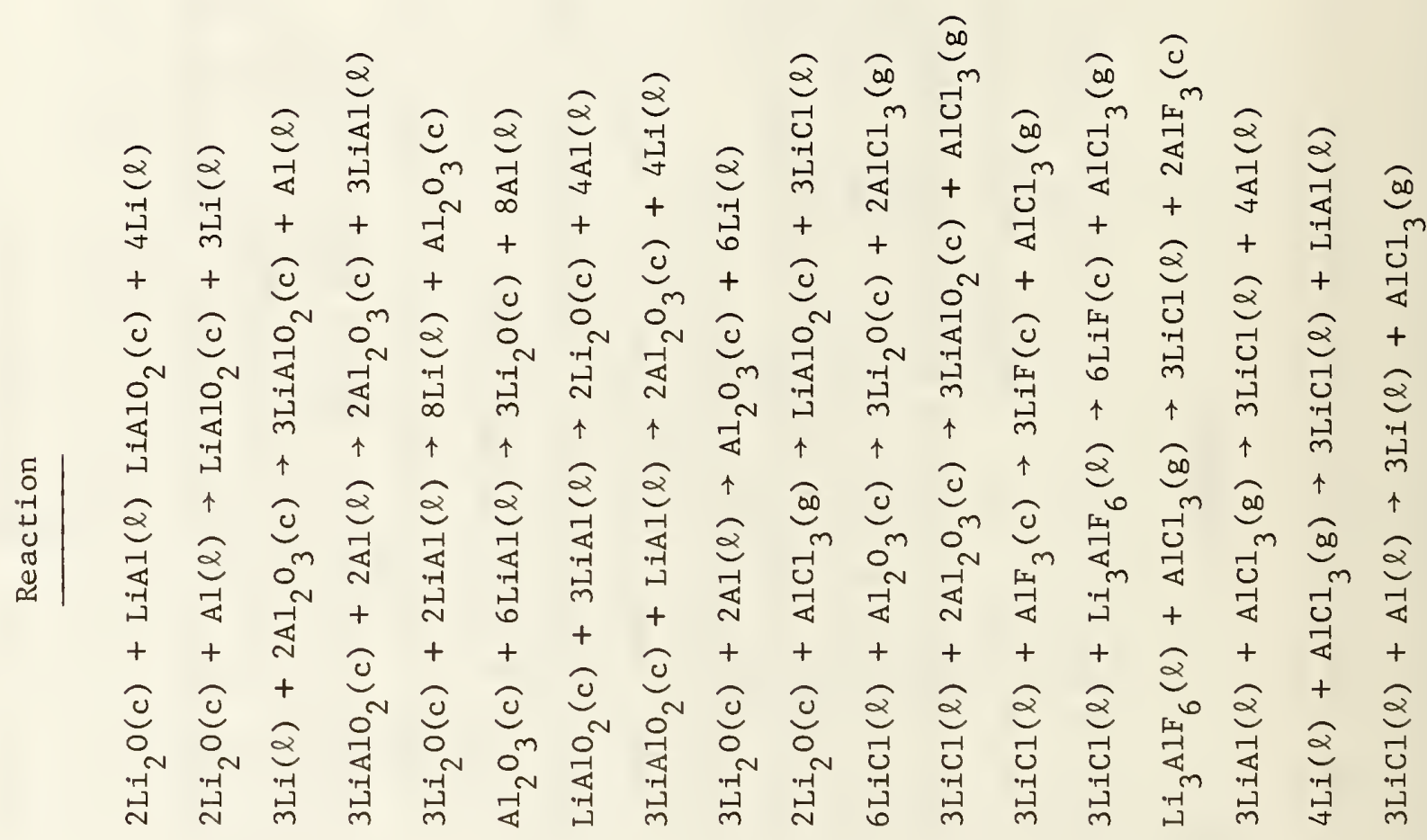

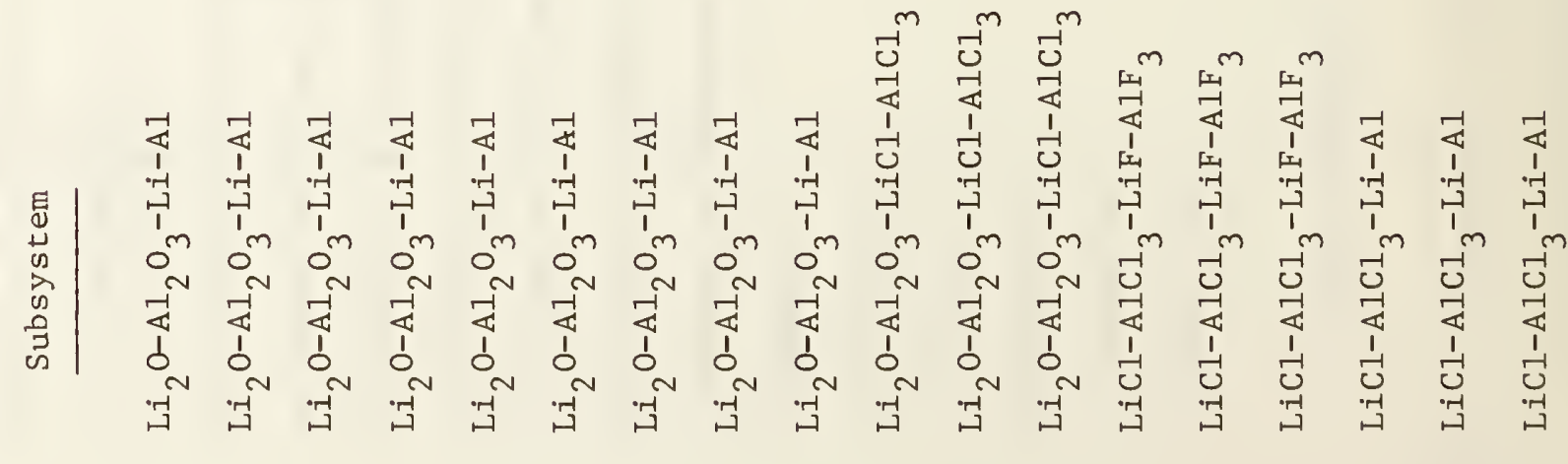

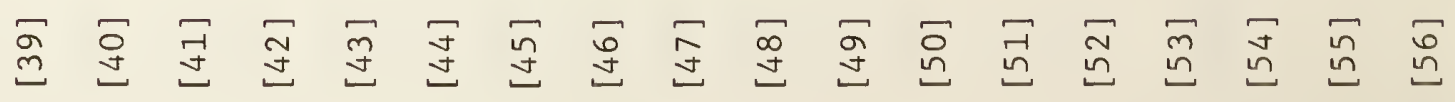




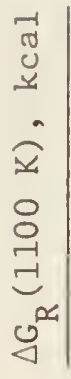

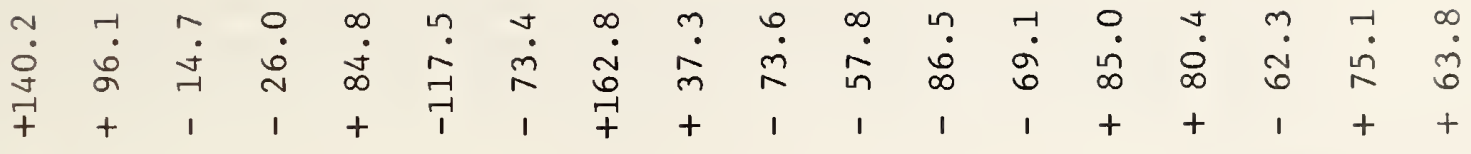

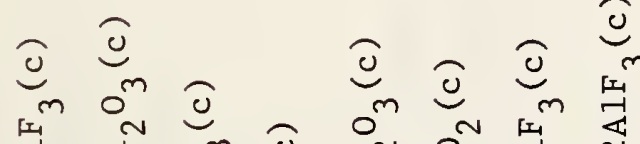

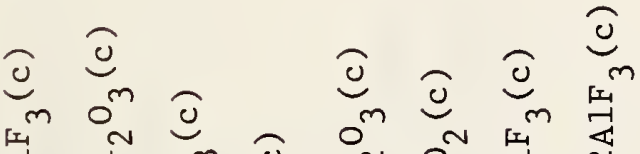

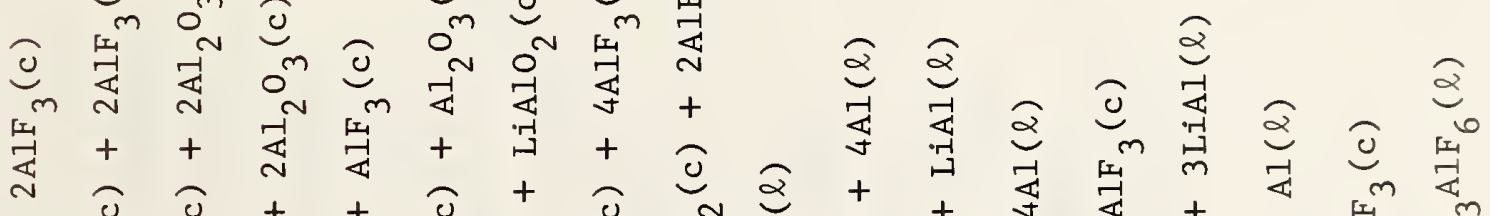

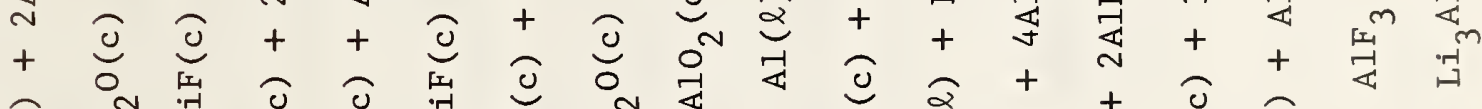

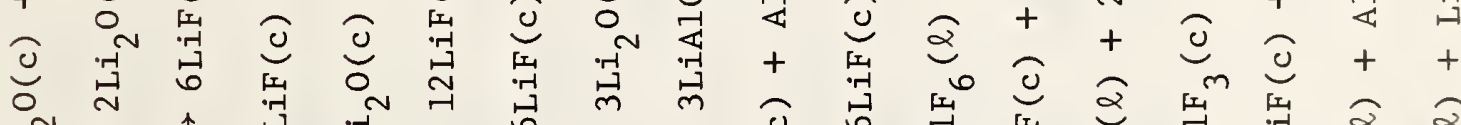

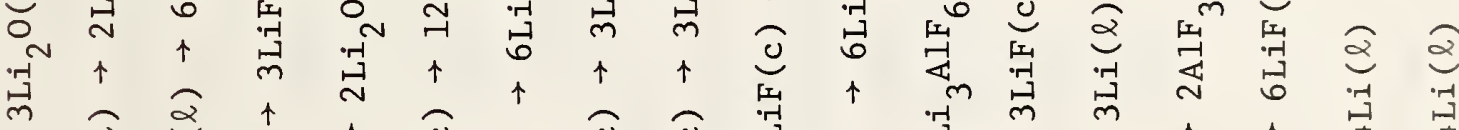

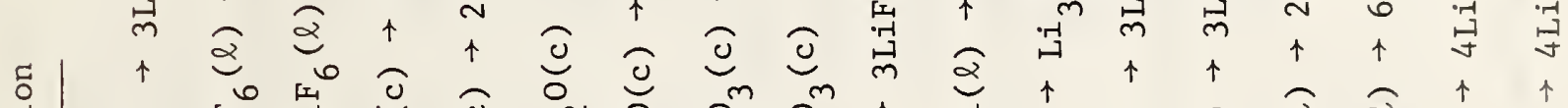

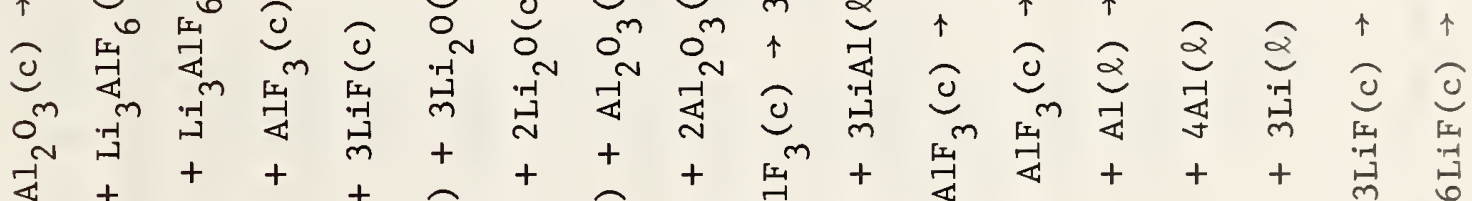

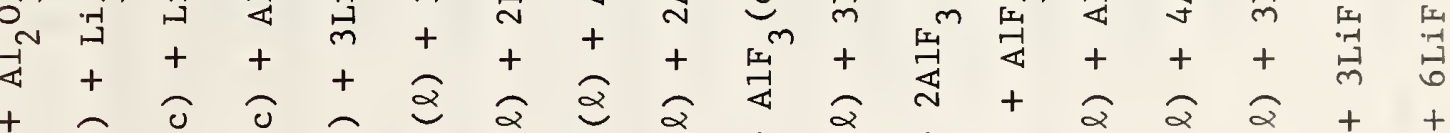

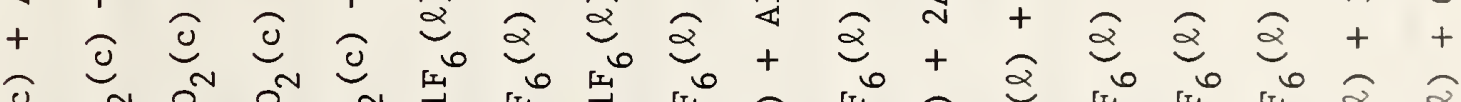

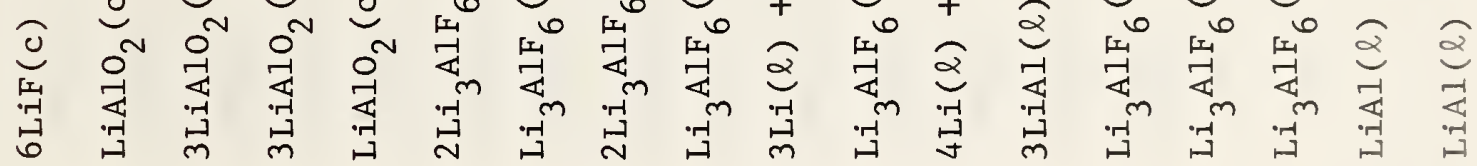

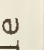




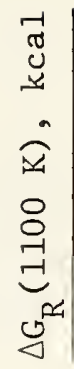

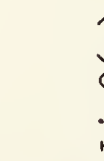

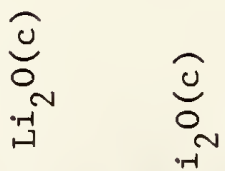

త

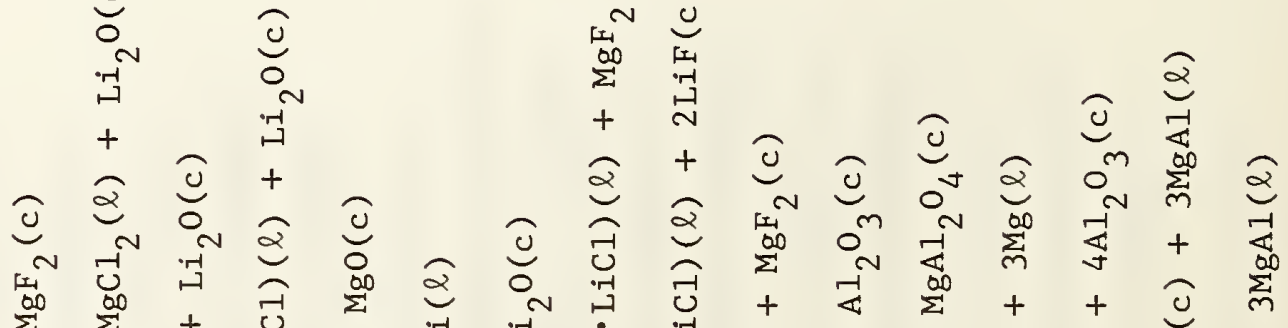

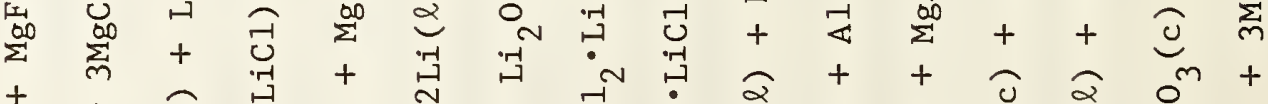

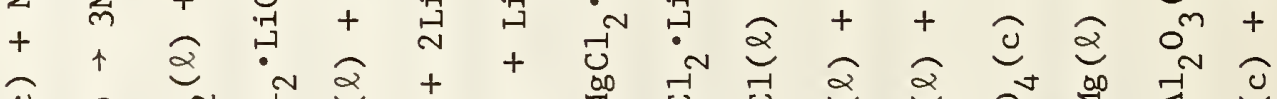

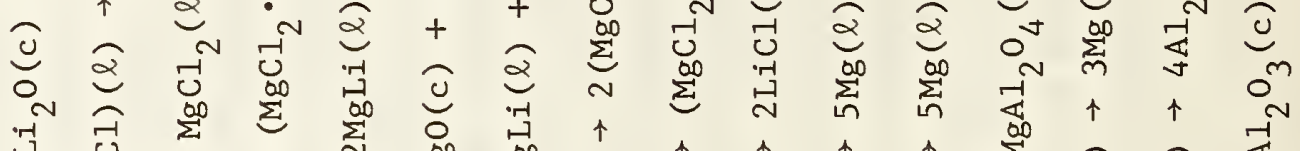

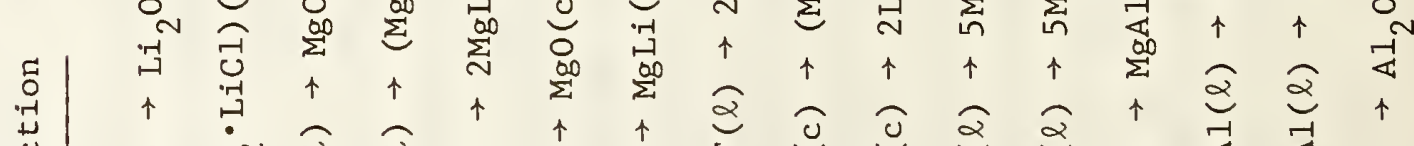

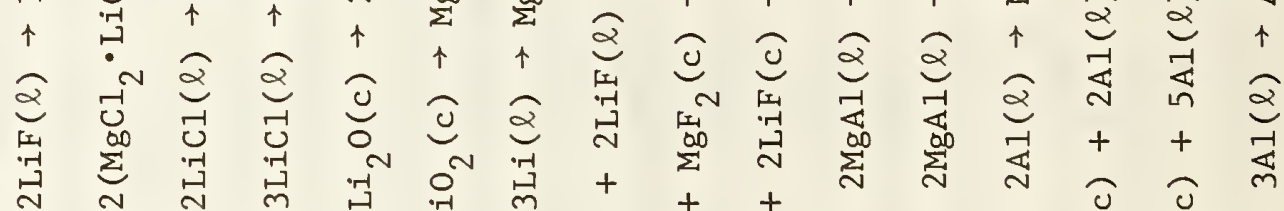

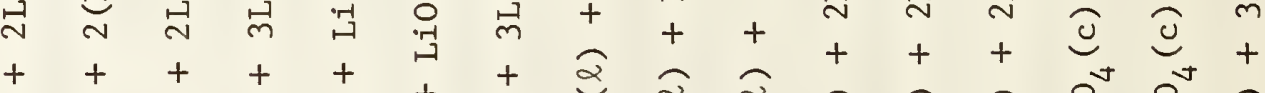

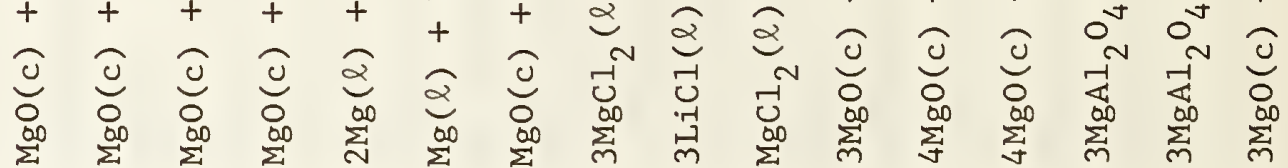

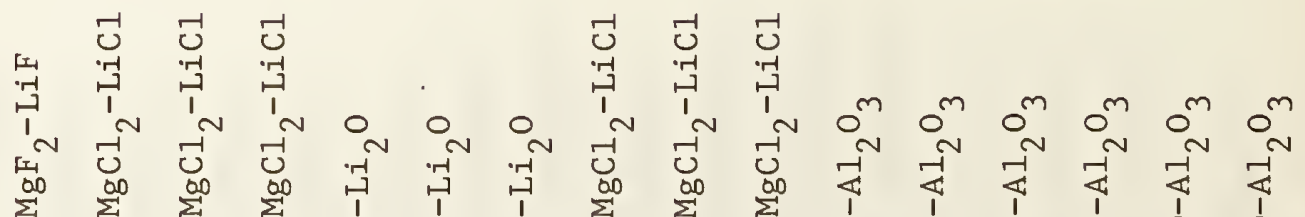

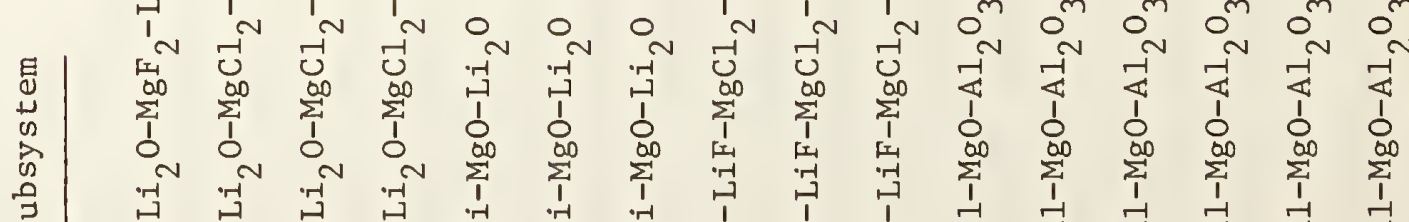

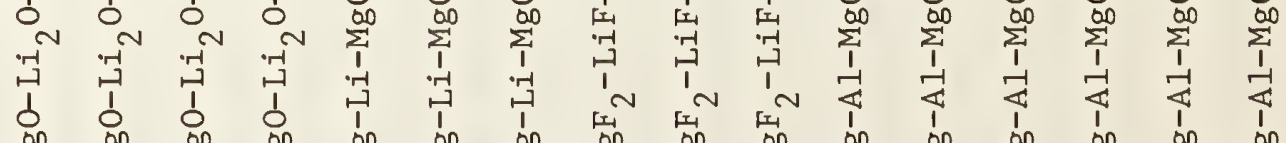




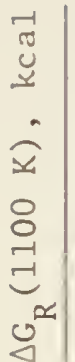

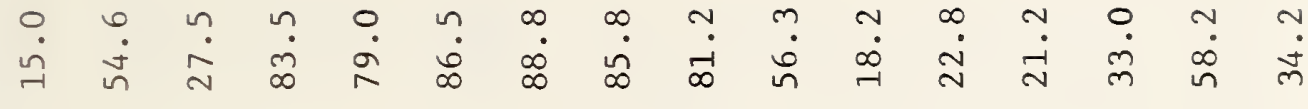

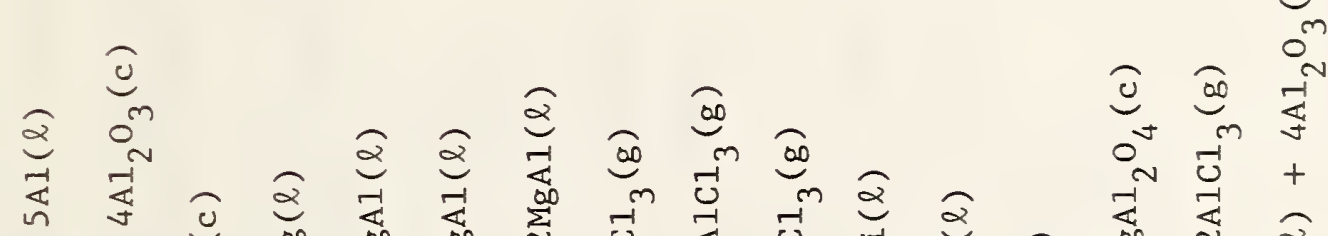

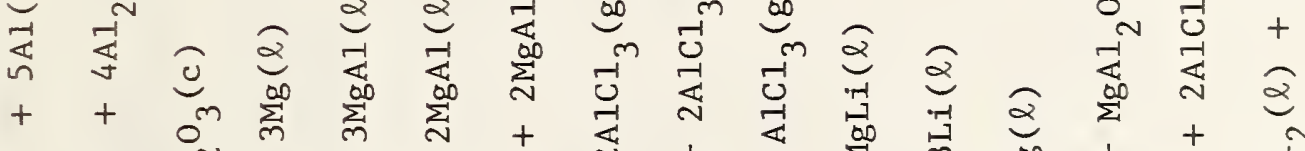

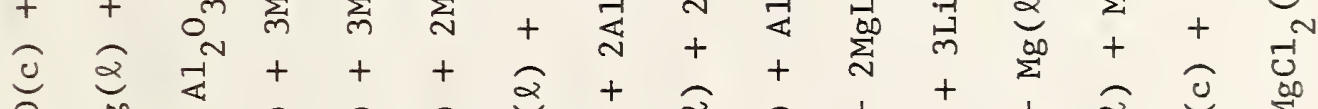

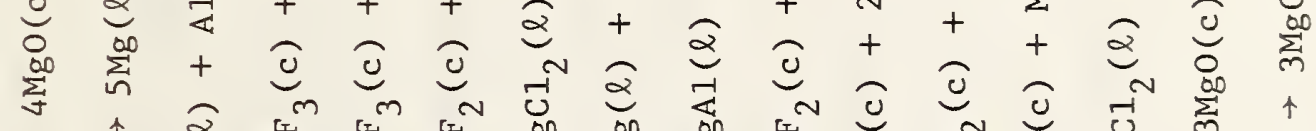

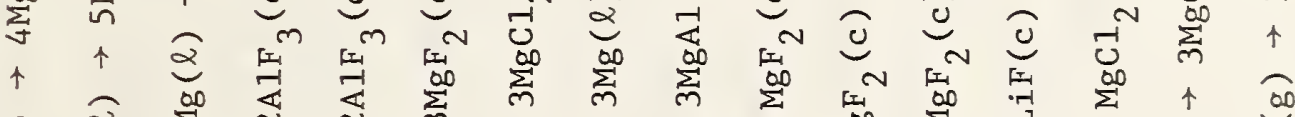

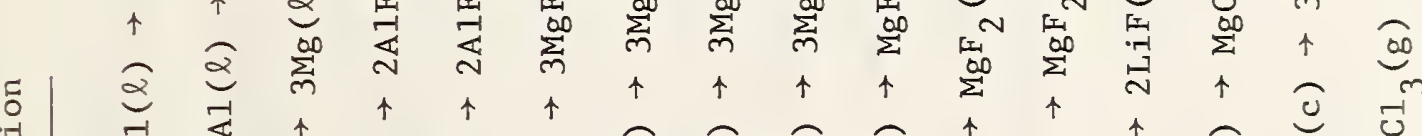

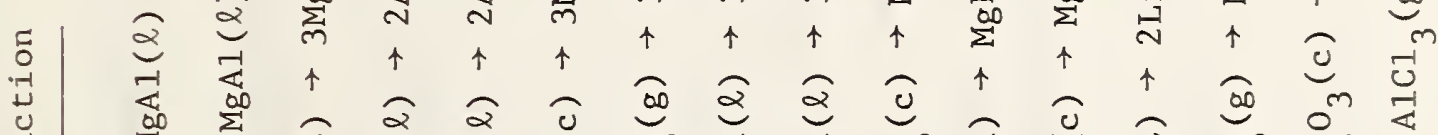

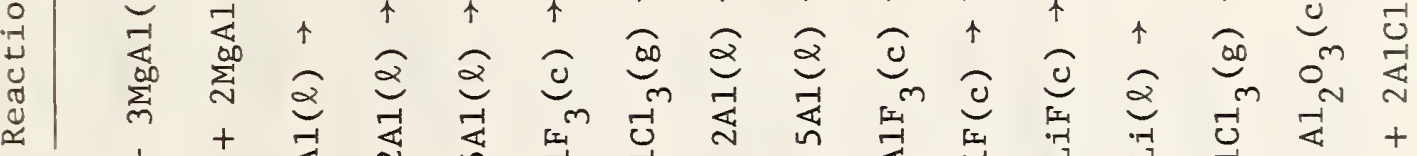

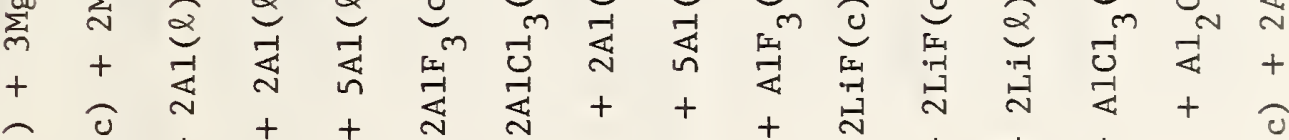

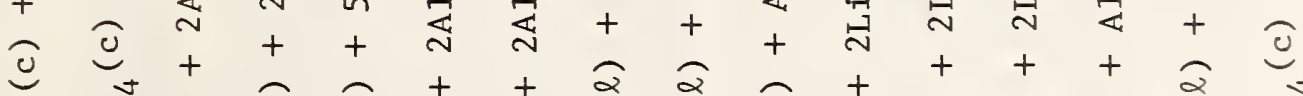

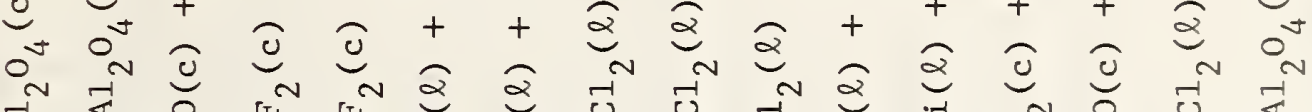

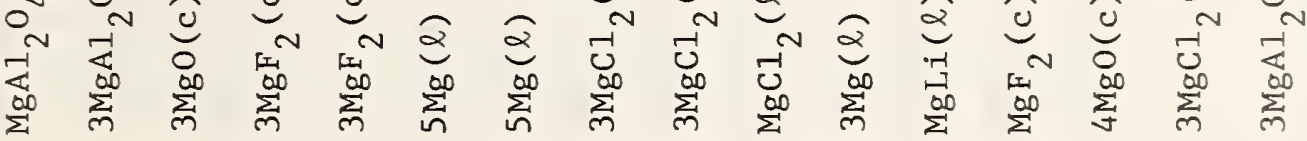


ป్

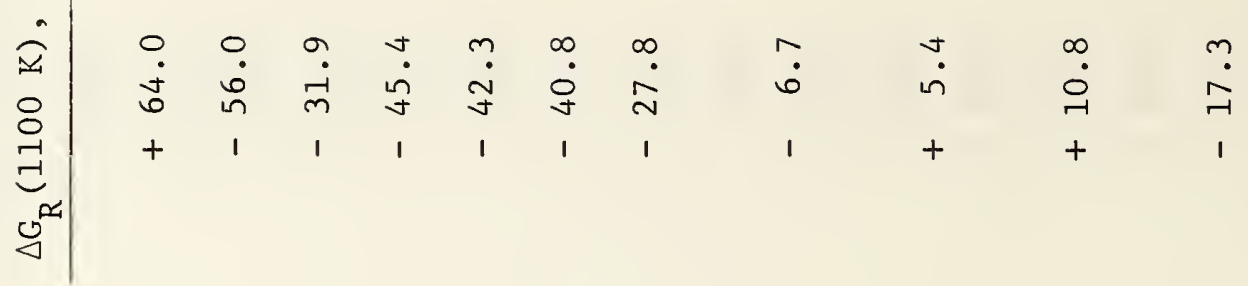
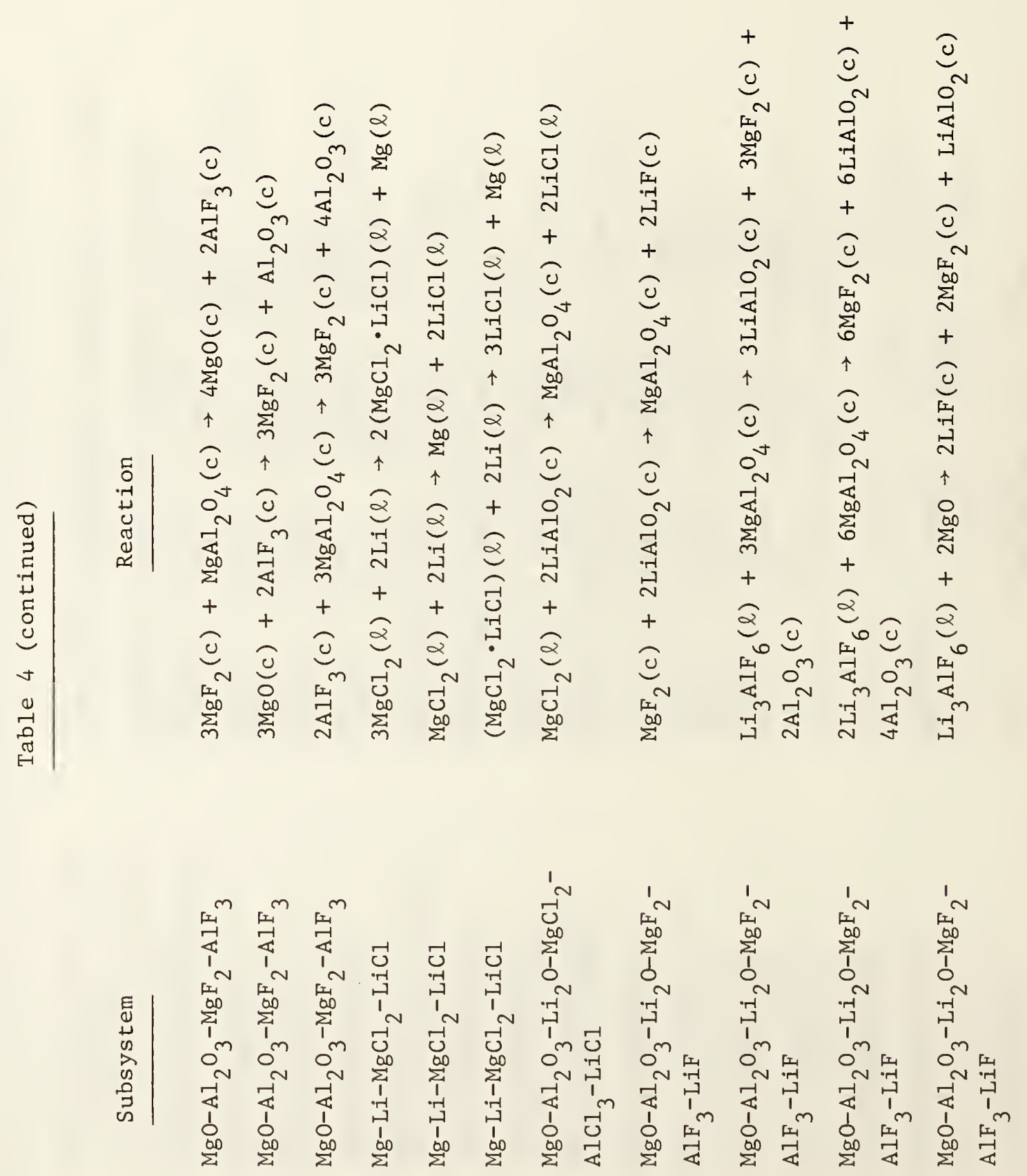


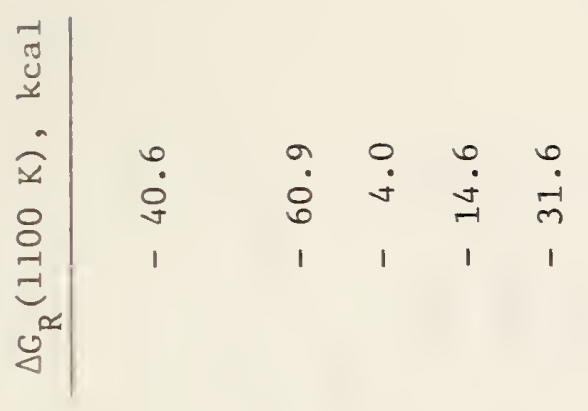
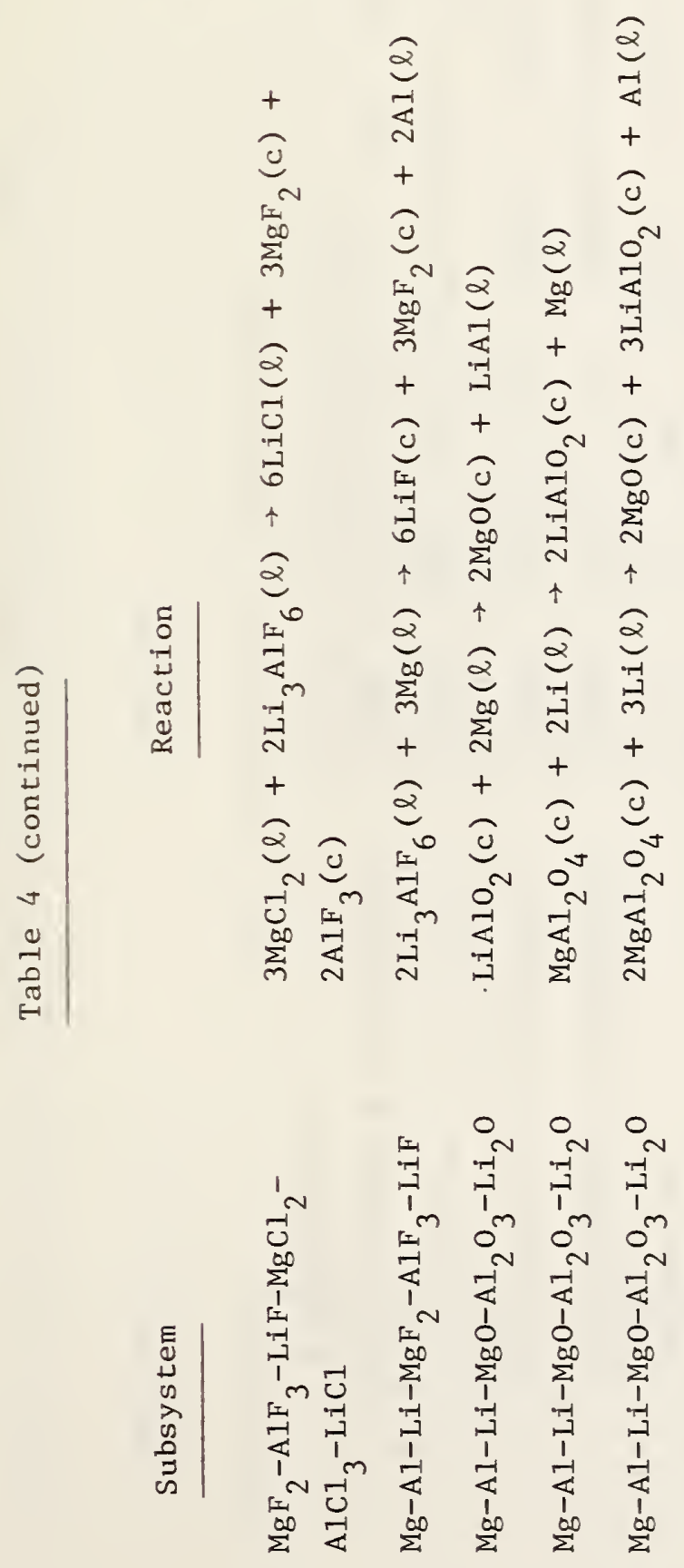

竎 


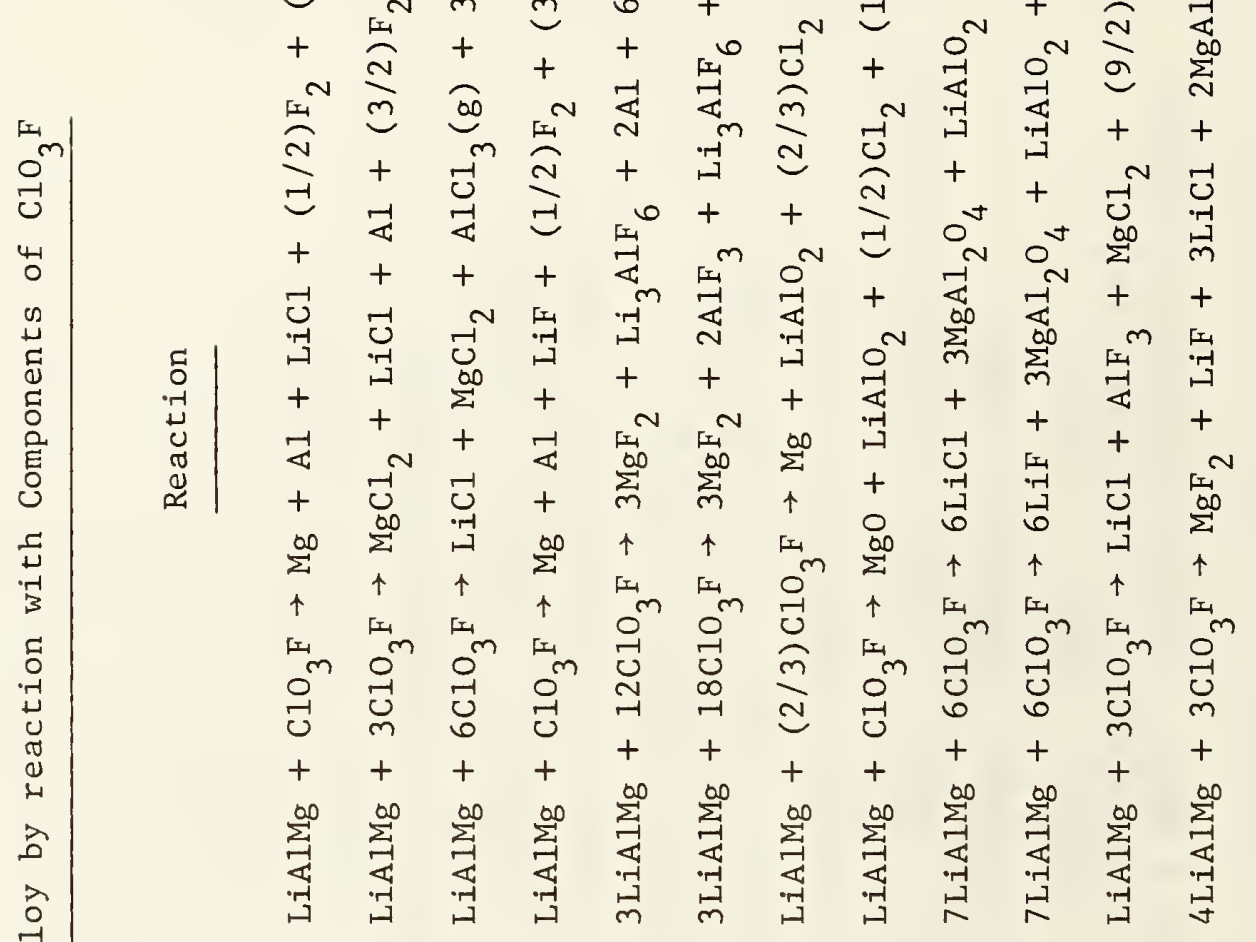

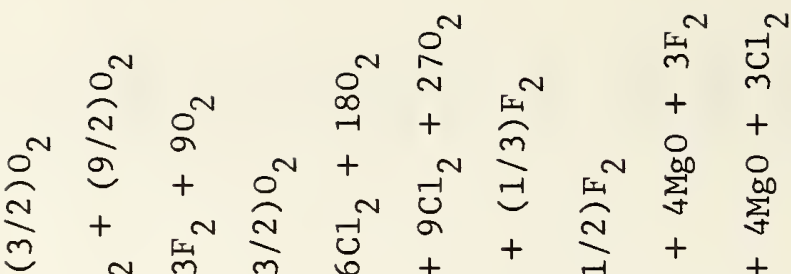

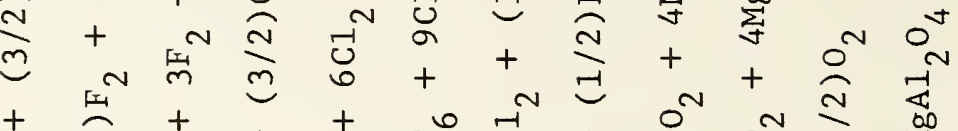

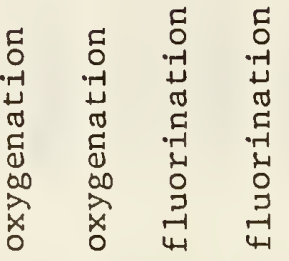

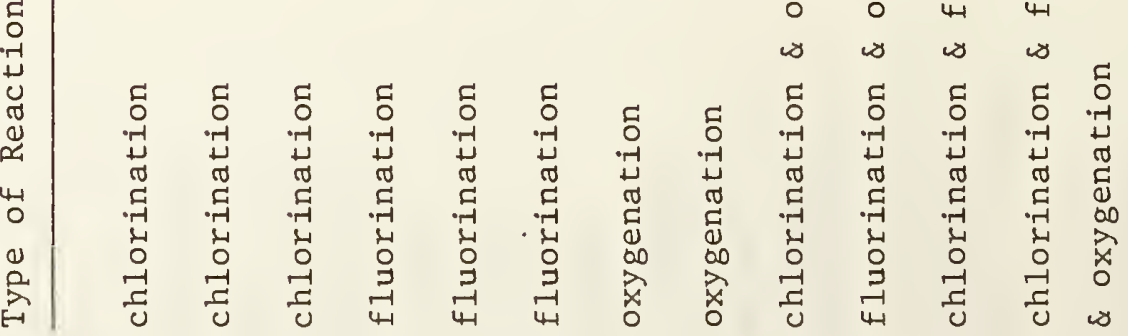

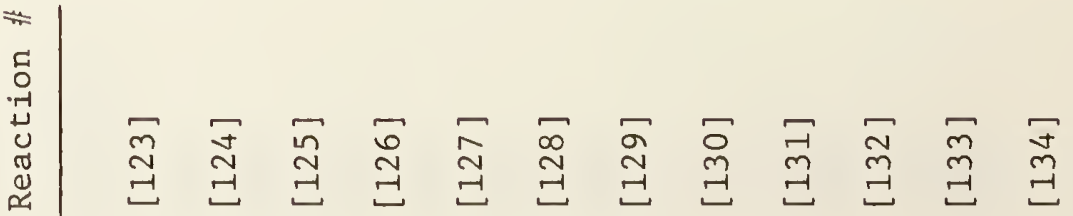




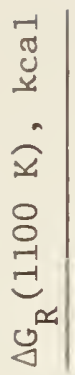

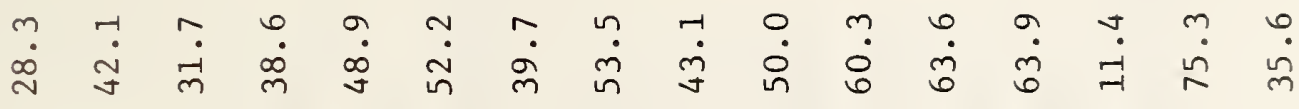

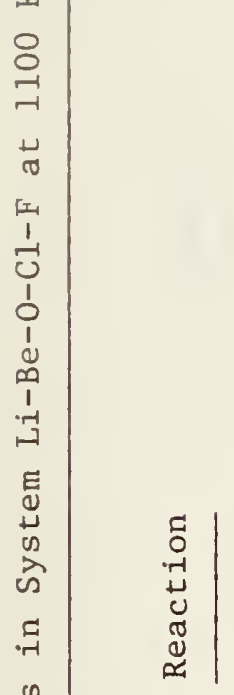

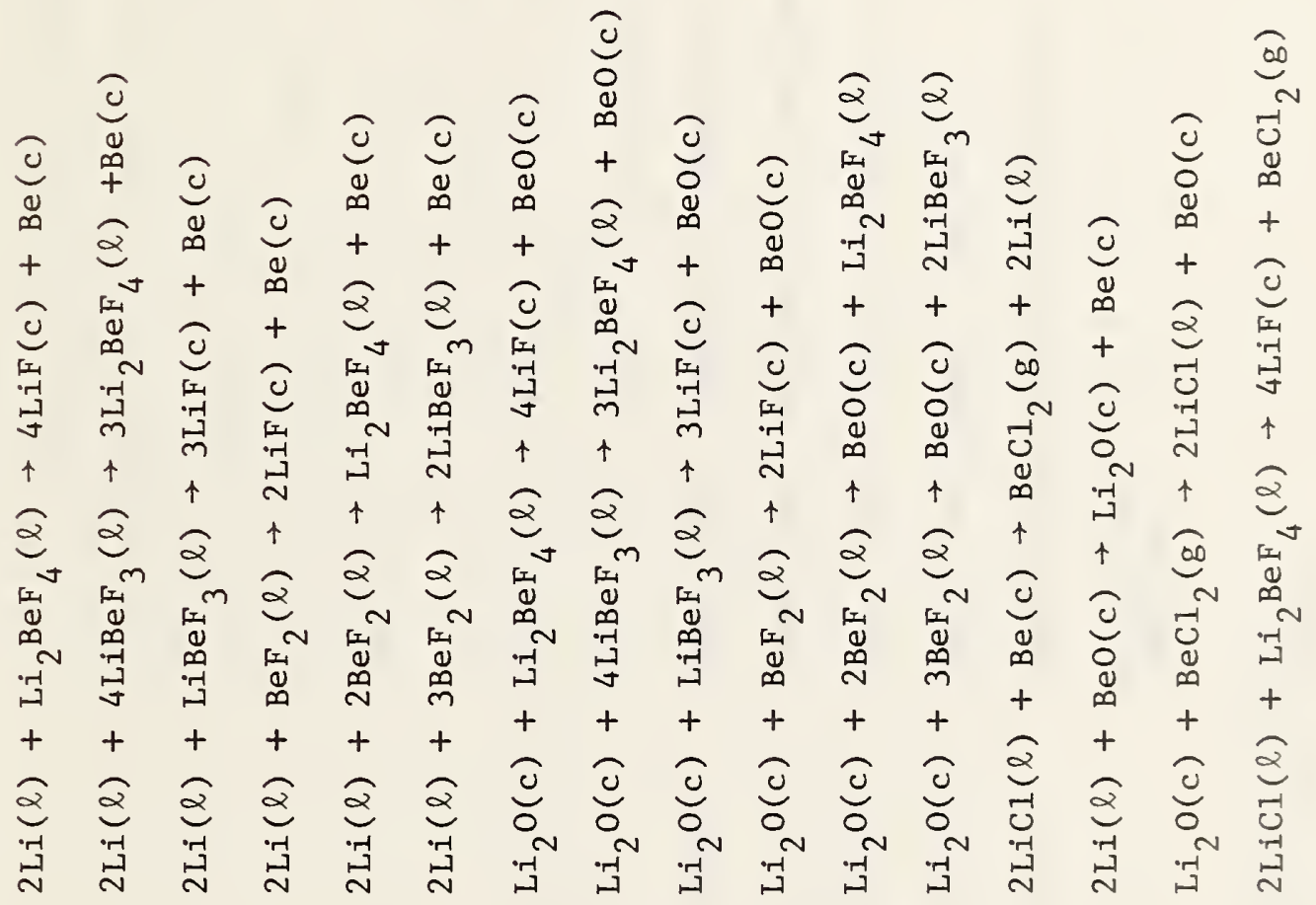




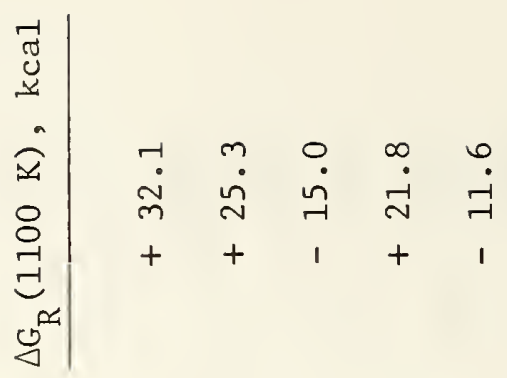

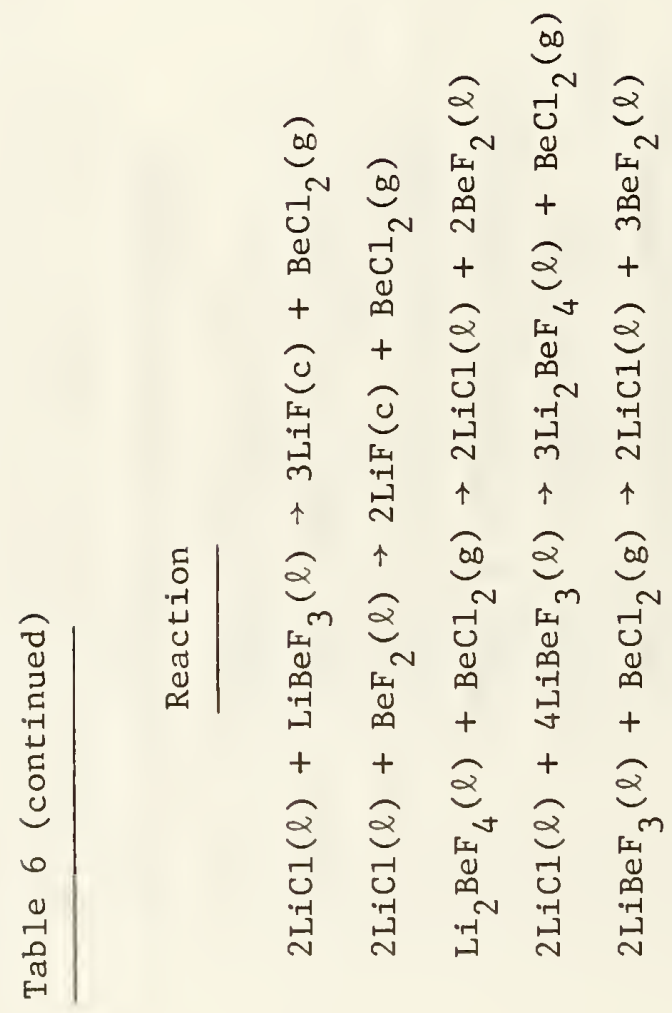

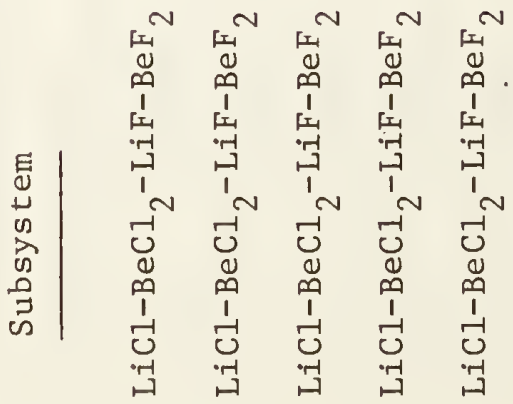

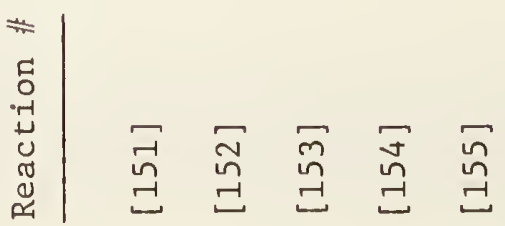




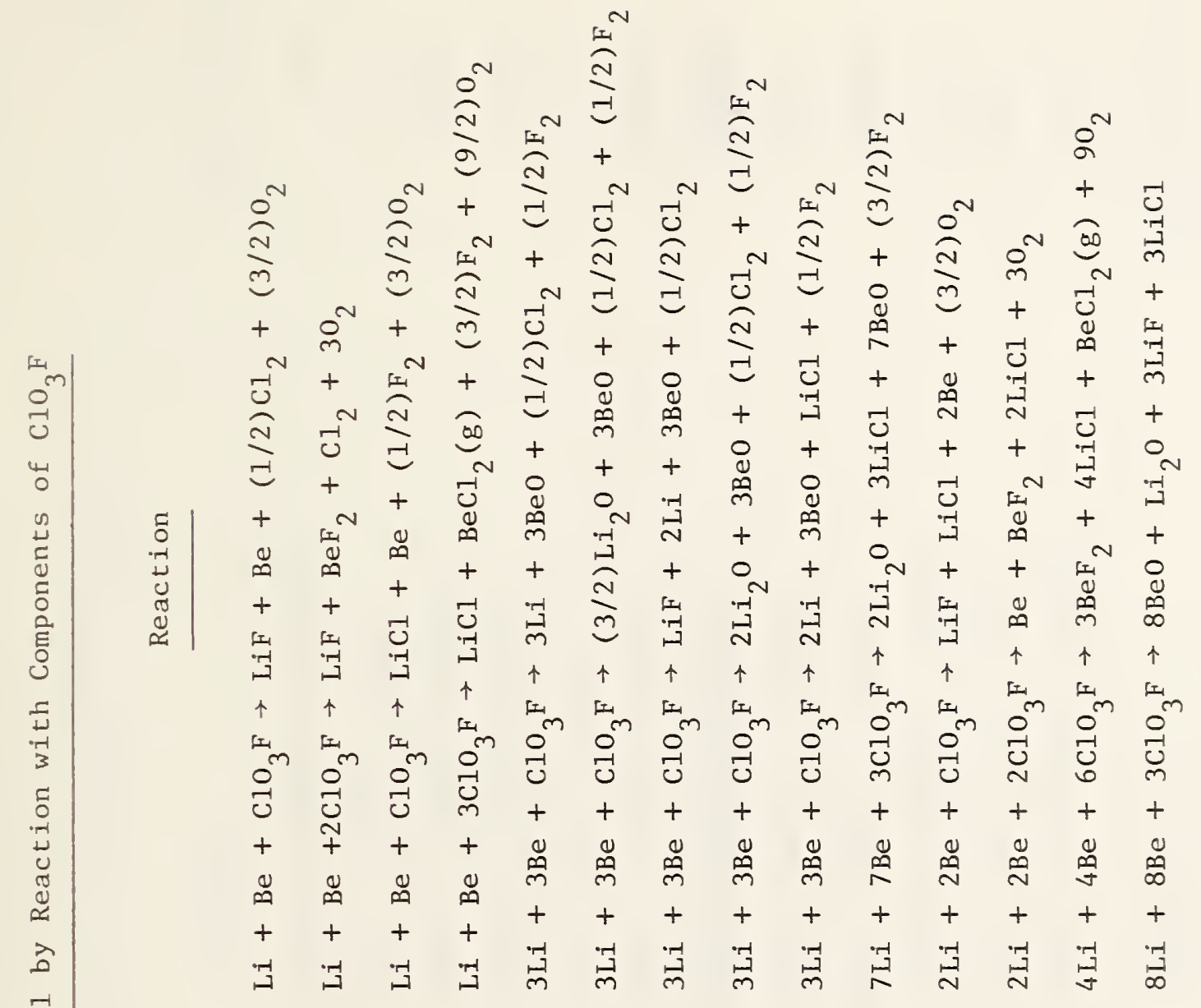




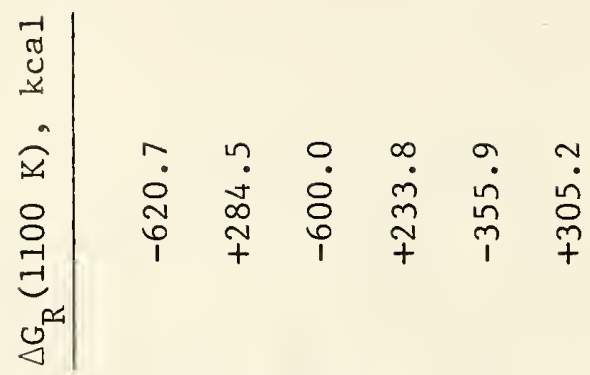

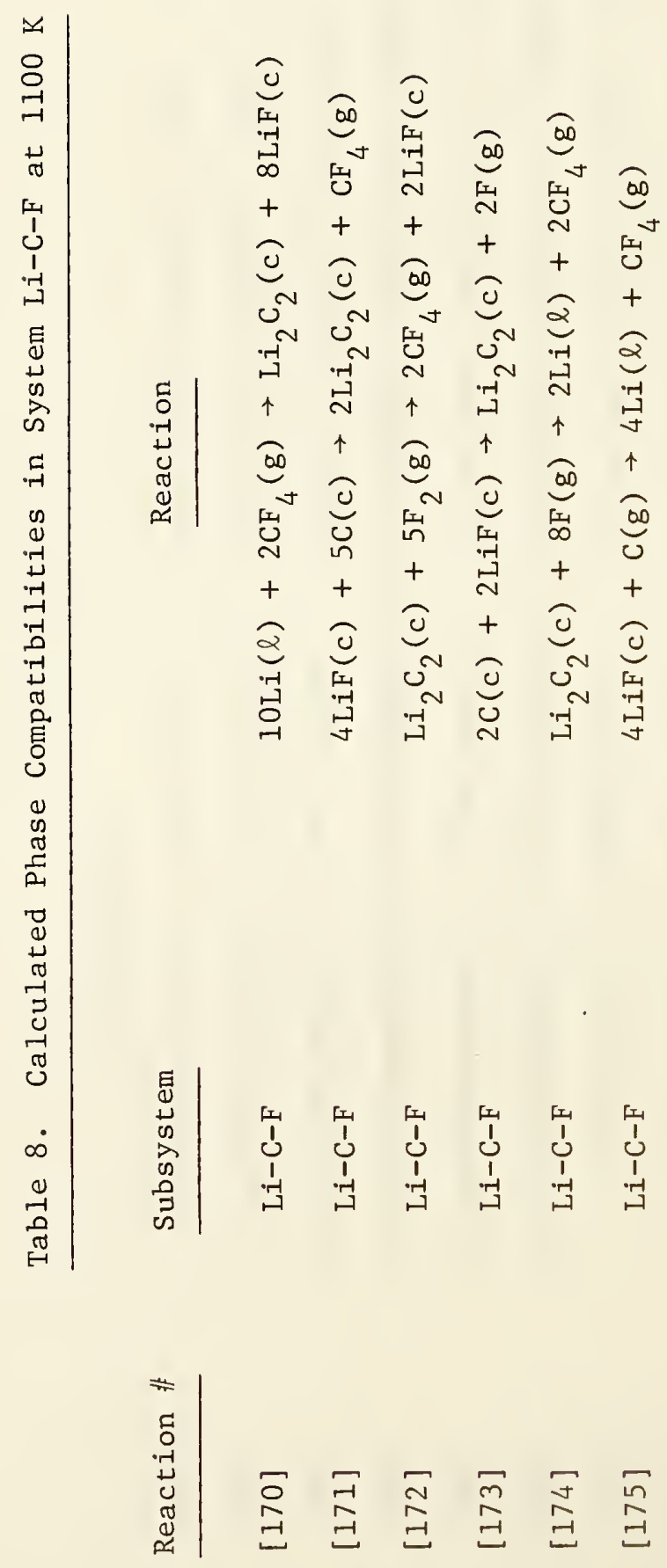


पु

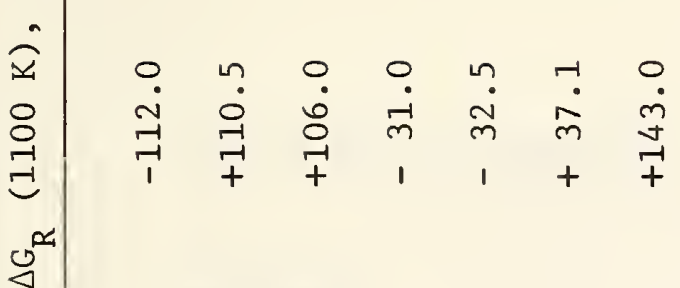

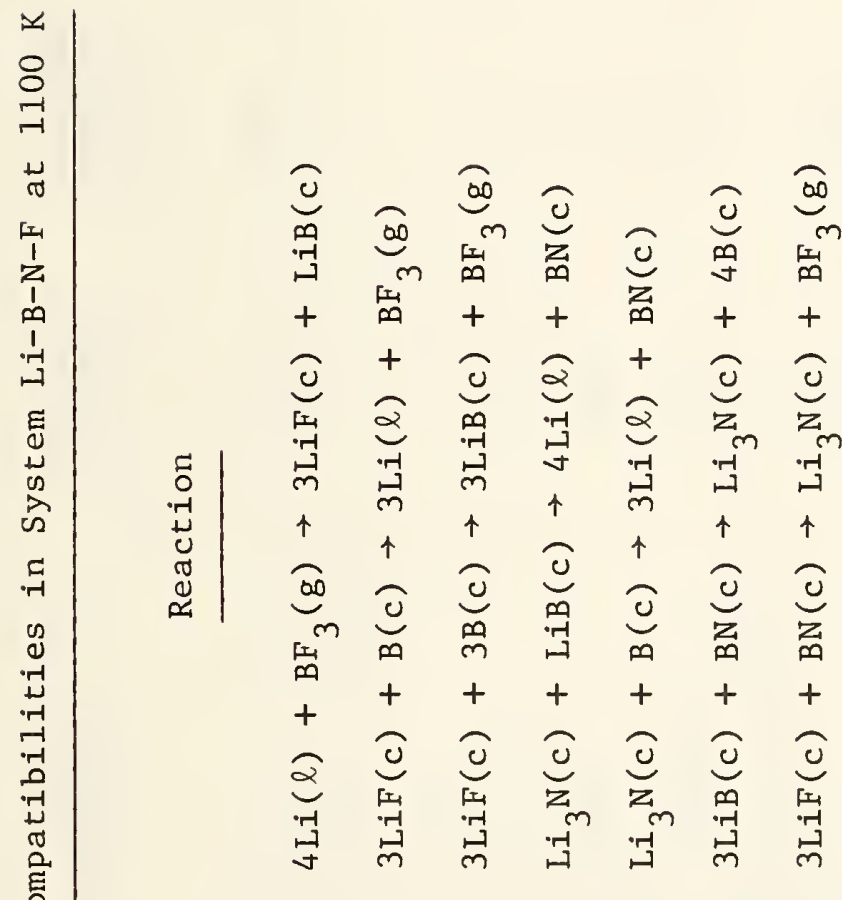

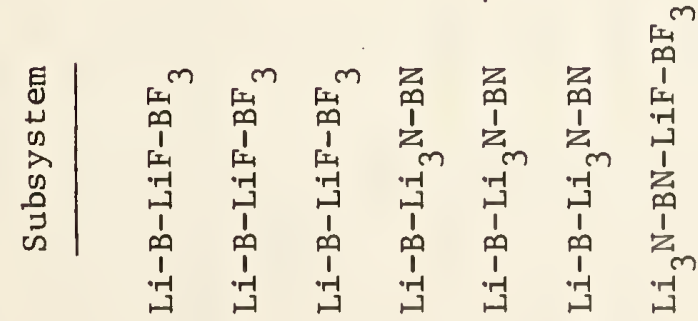

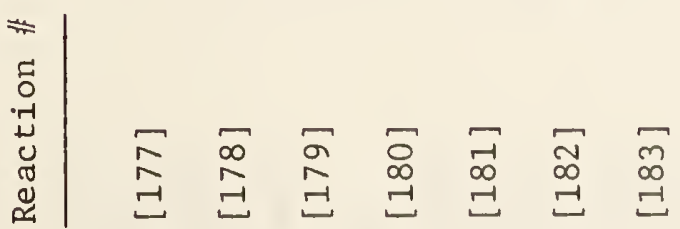


Table 10. Progressive Oxidation of LiB by $\mathrm{NF}_{3}$

Reaction 非

[184]

[185]

\section{Reaction}

$3 \mathrm{LiB}+\mathrm{NF}_{3} \rightarrow 2 \mathrm{~B}+3 \mathrm{LiF}+\mathrm{BN}$

$3 \mathrm{LiB}+2 \mathrm{NF}_{3} \rightarrow 3 \mathrm{LiF}+\mathrm{BF}_{3}+2 \mathrm{BN}$ 


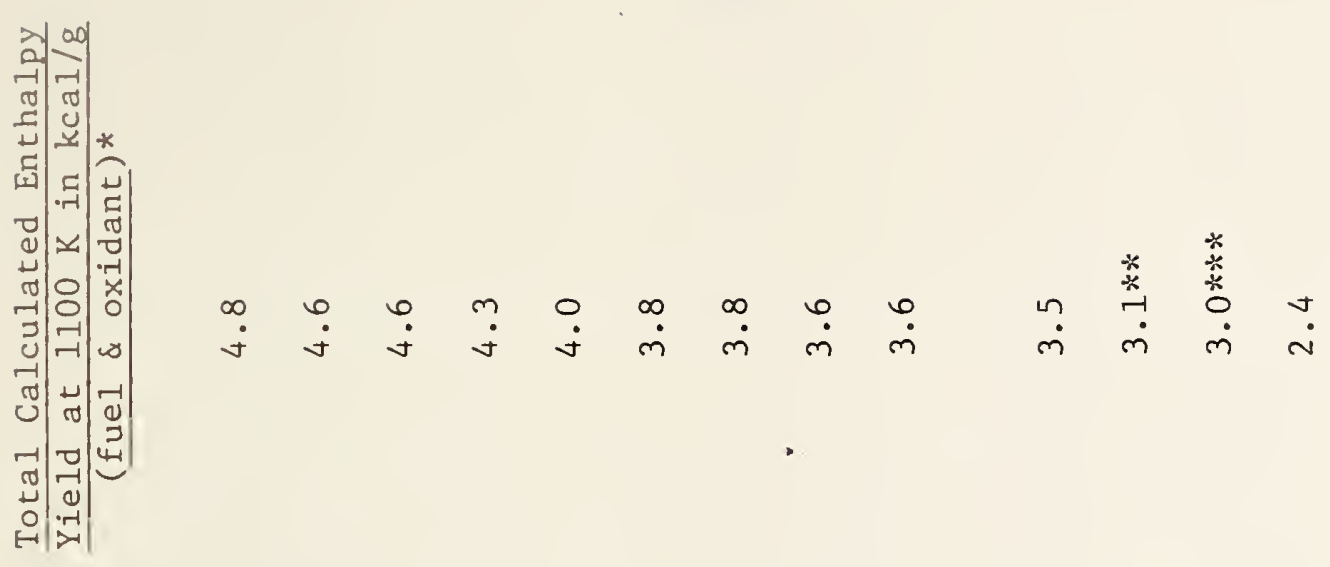

党|

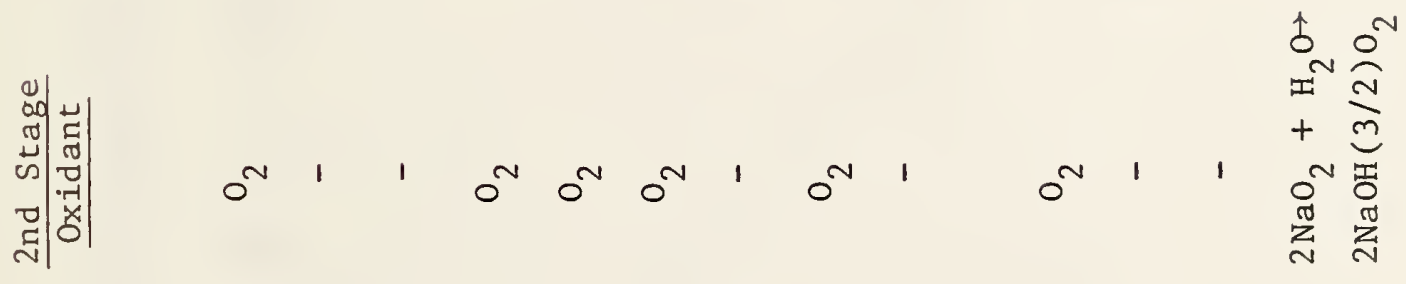

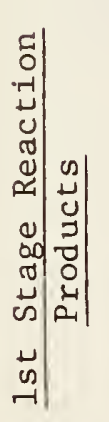

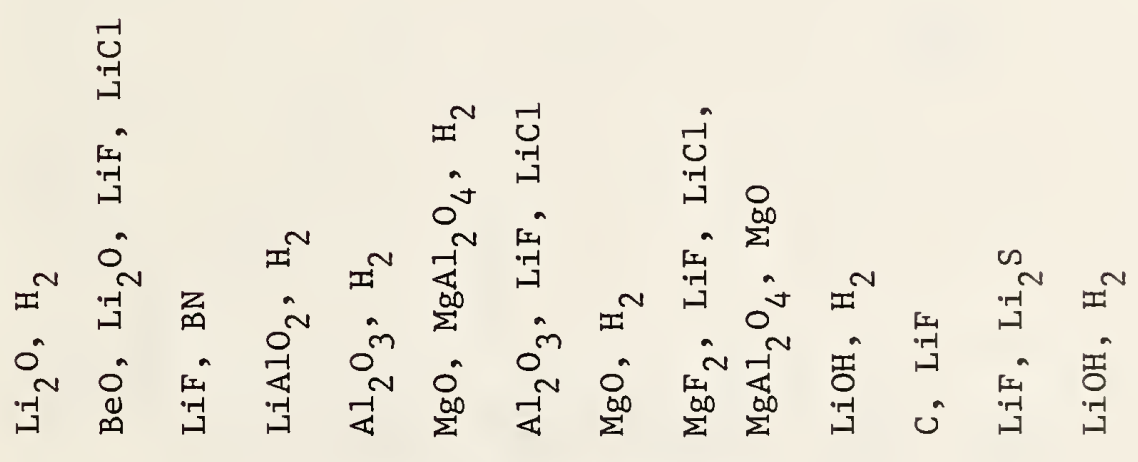

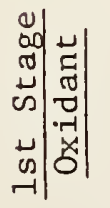

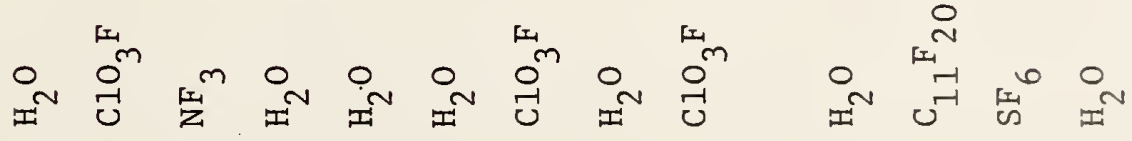

|-1.1.

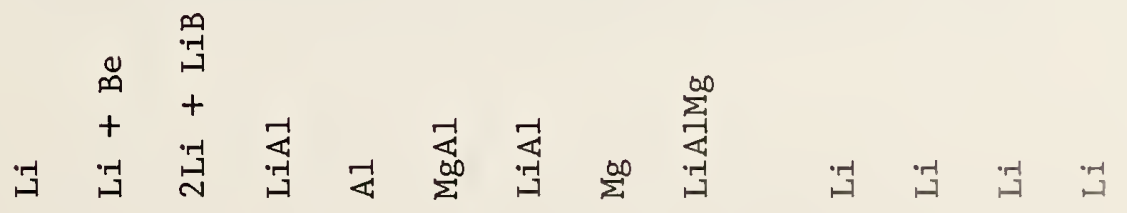


$-80-$

XV. Figures 


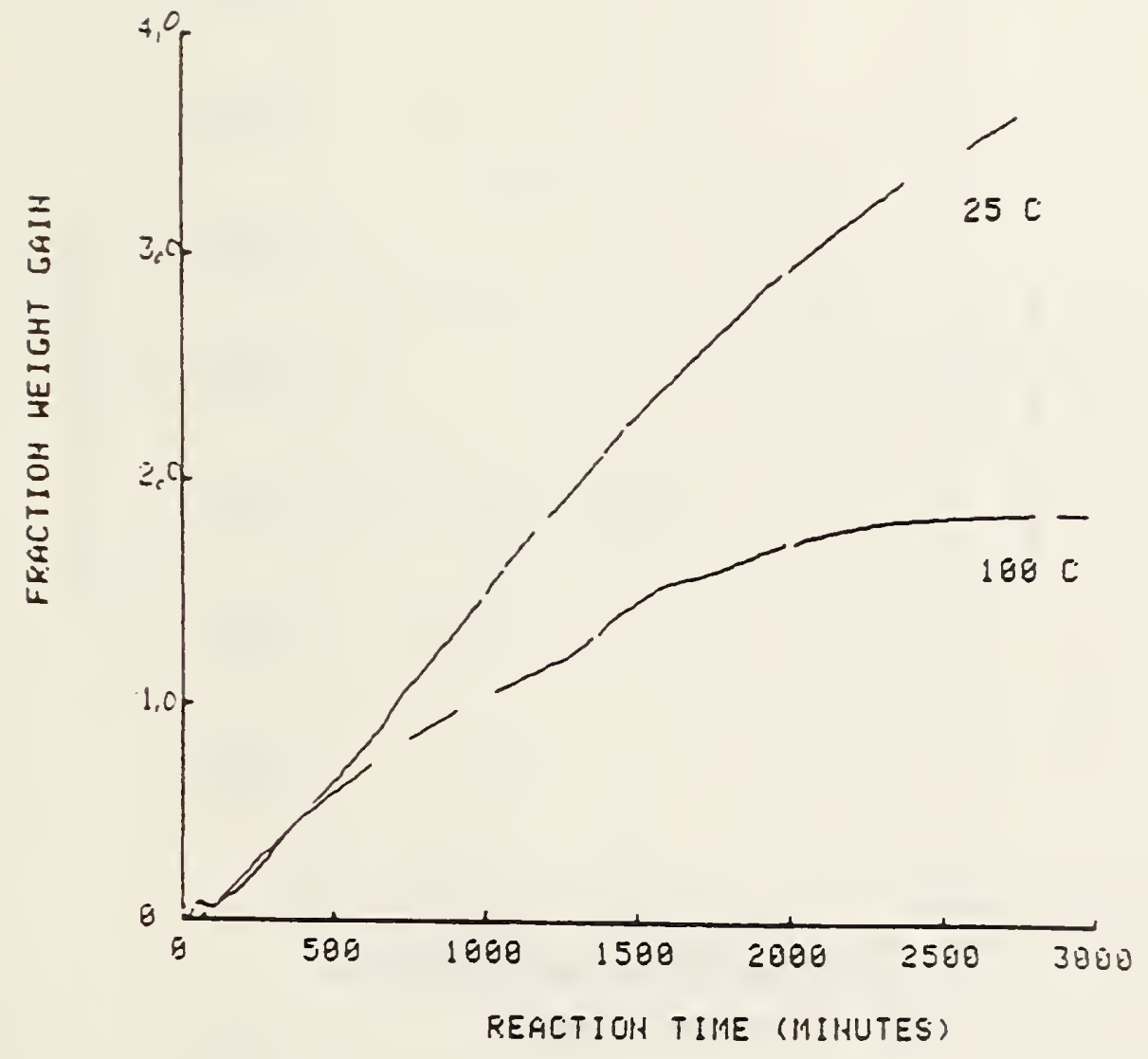

Figure 1. Thermogravimetric analysis of reaction of powdered lithium metal with flowing water-saturated argon at 25 and $100{ }^{\circ} \mathrm{C}$. 


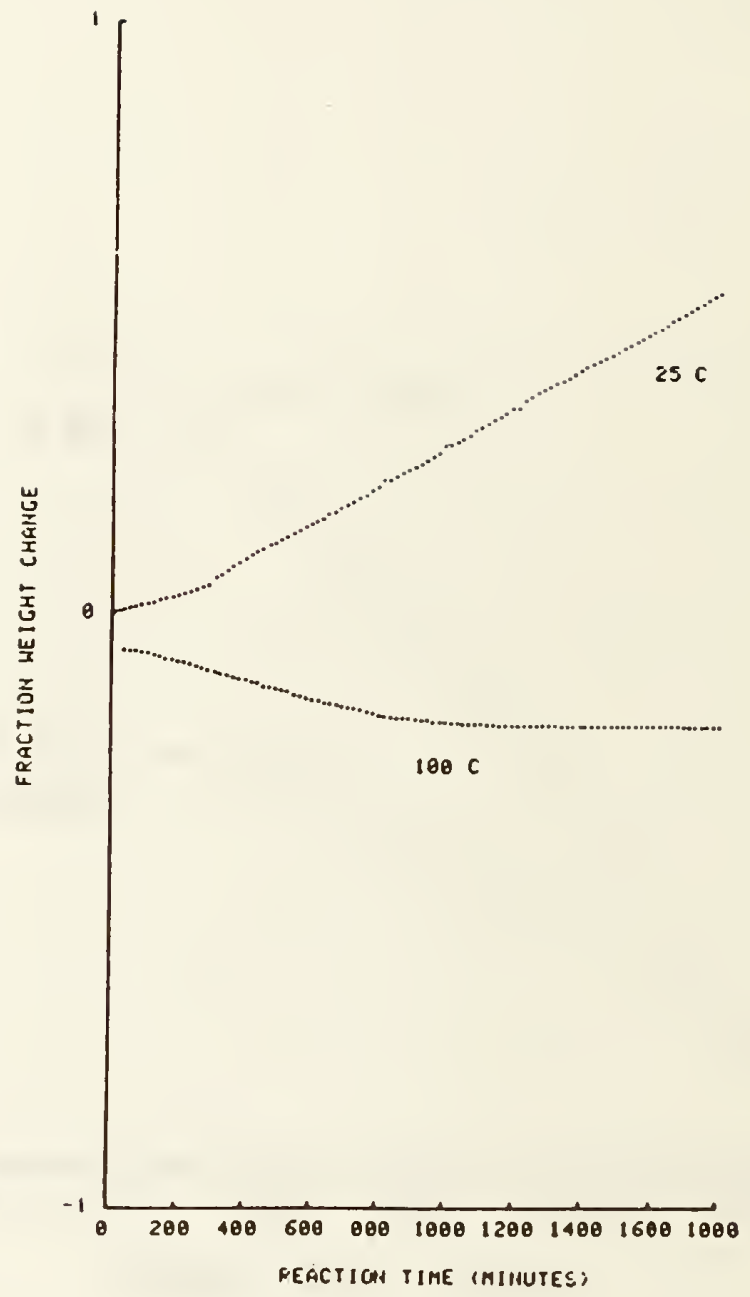

Figure 2. Thermogravimetric analysis of reaction of powdered sodium superoxide with flowing water-saturated argon at 25 and $100{ }^{\circ} \mathrm{C}$. 


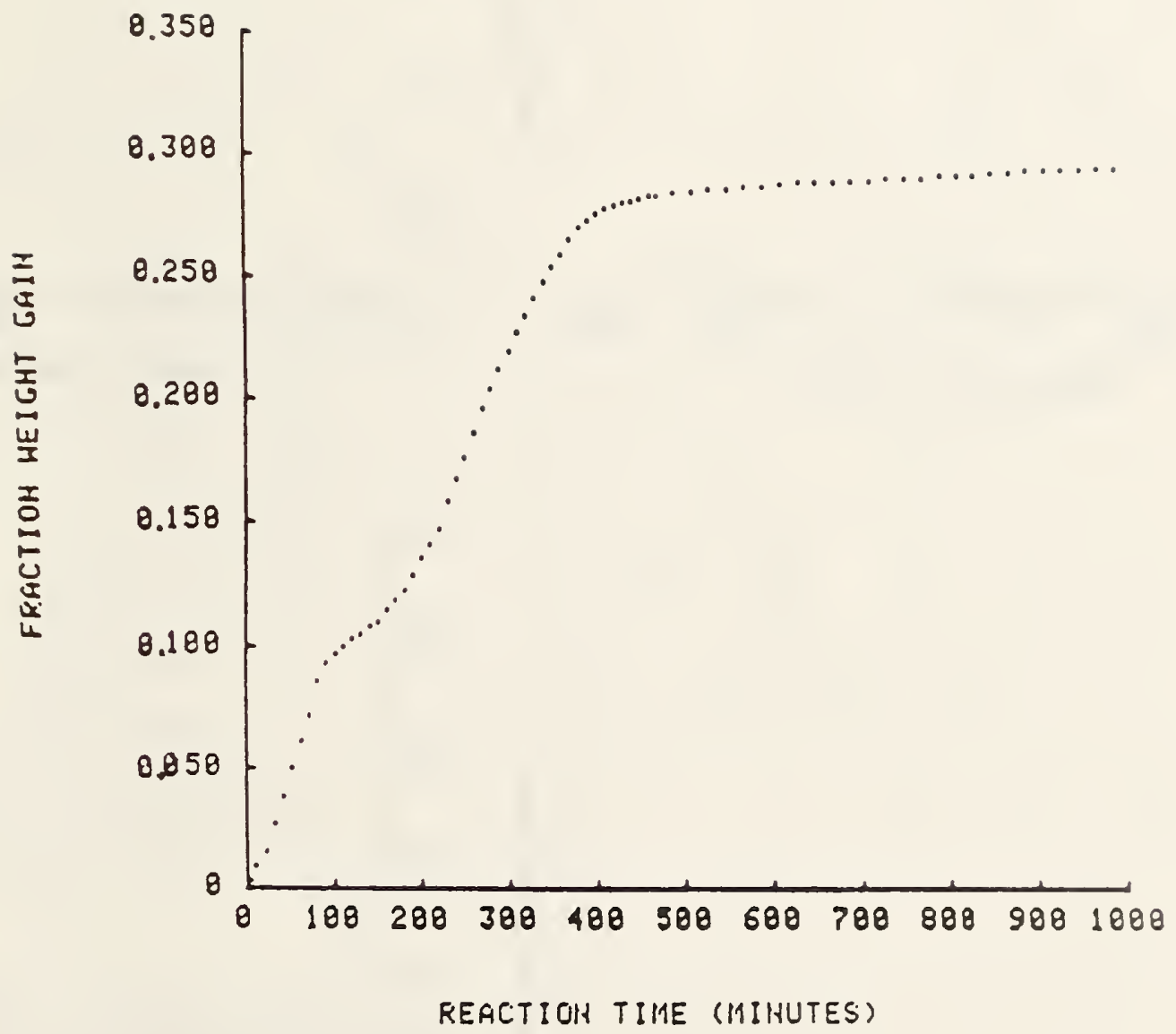

Figure 3. Thermogravimetric analysis of reaction of nowdered MgAl alloy with flowing water-saturated argon at $650{ }^{\circ} \mathrm{C}$. 


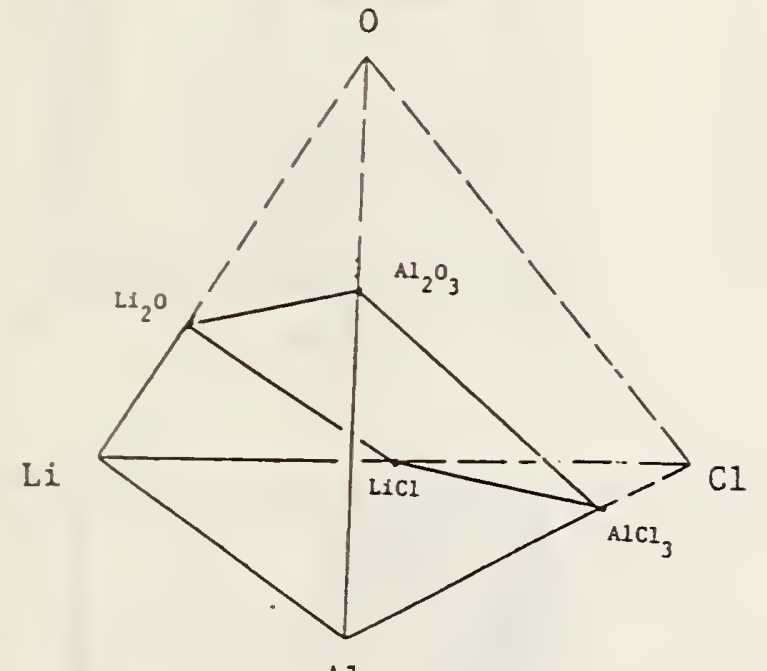

Al
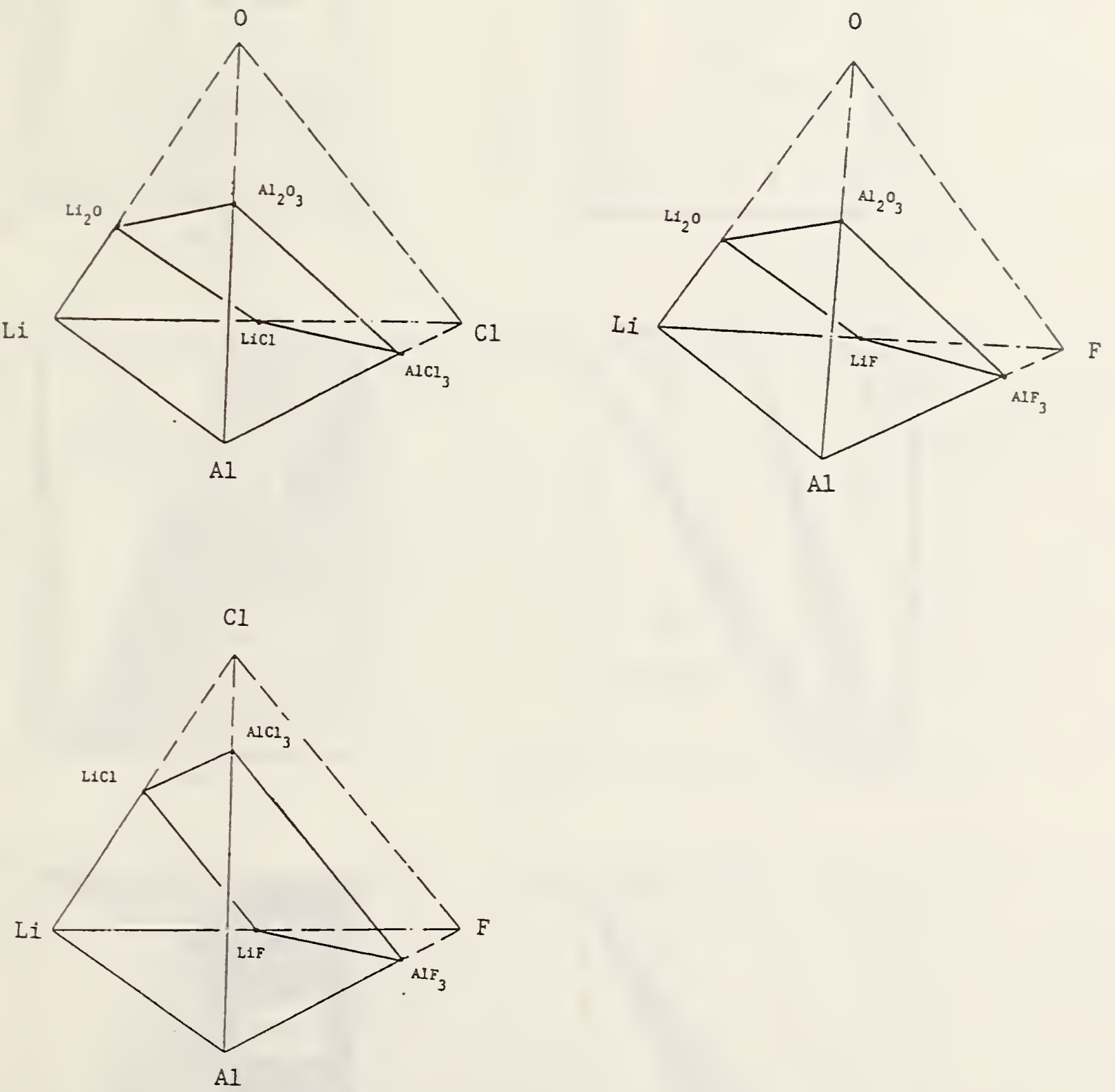

Figure 5. Quaternary reciprocal systems relevant to oxidation of LiAl alloy by $\mathrm{ClO}_{3} \mathrm{~F}$. 

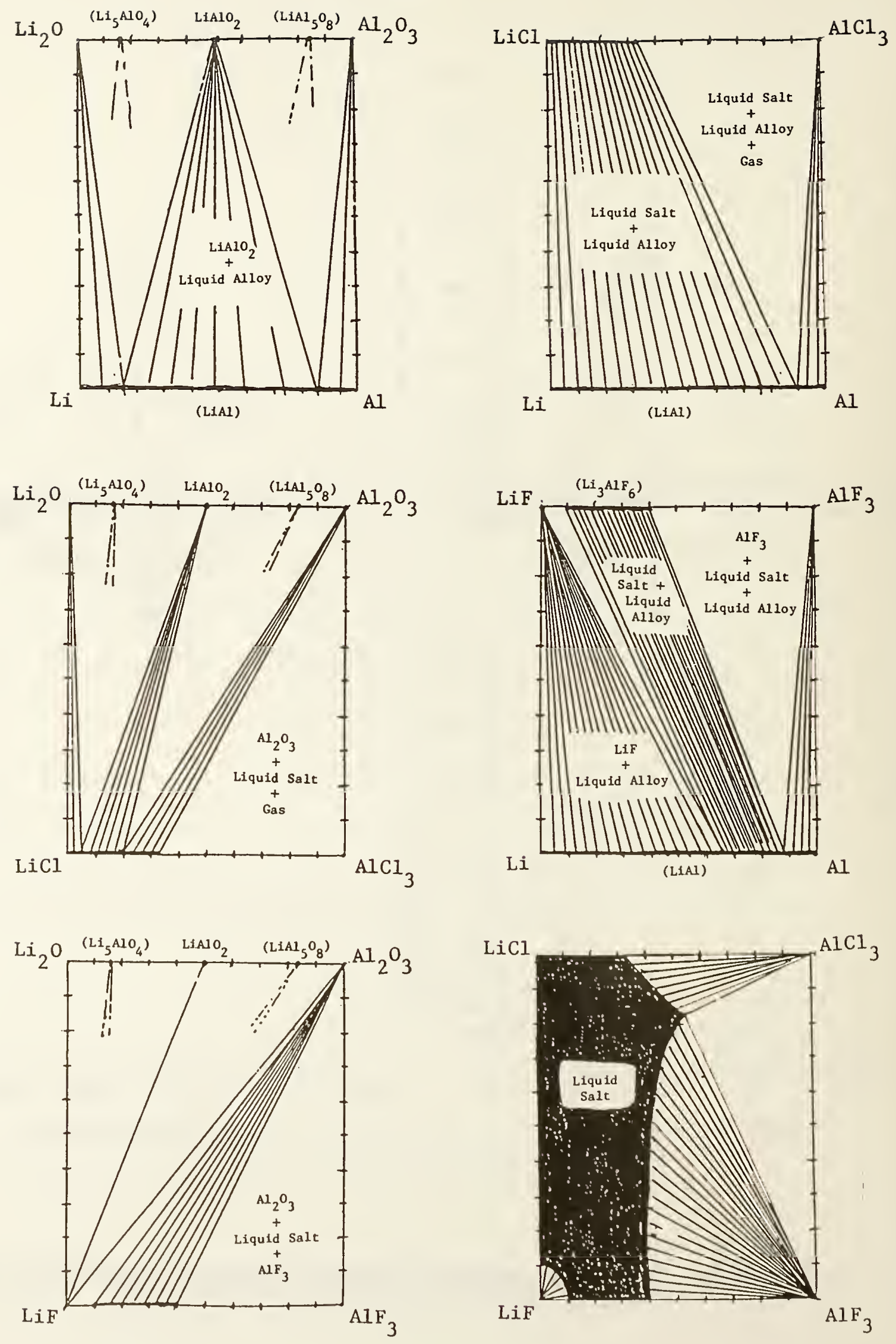

Figure 6. Calculated phase compatibilities in ternary reciprocal subsystems of the system Li-A1-Cl-O-F at $1100 \mathrm{~K}, 1 \mathrm{~atm}$. 

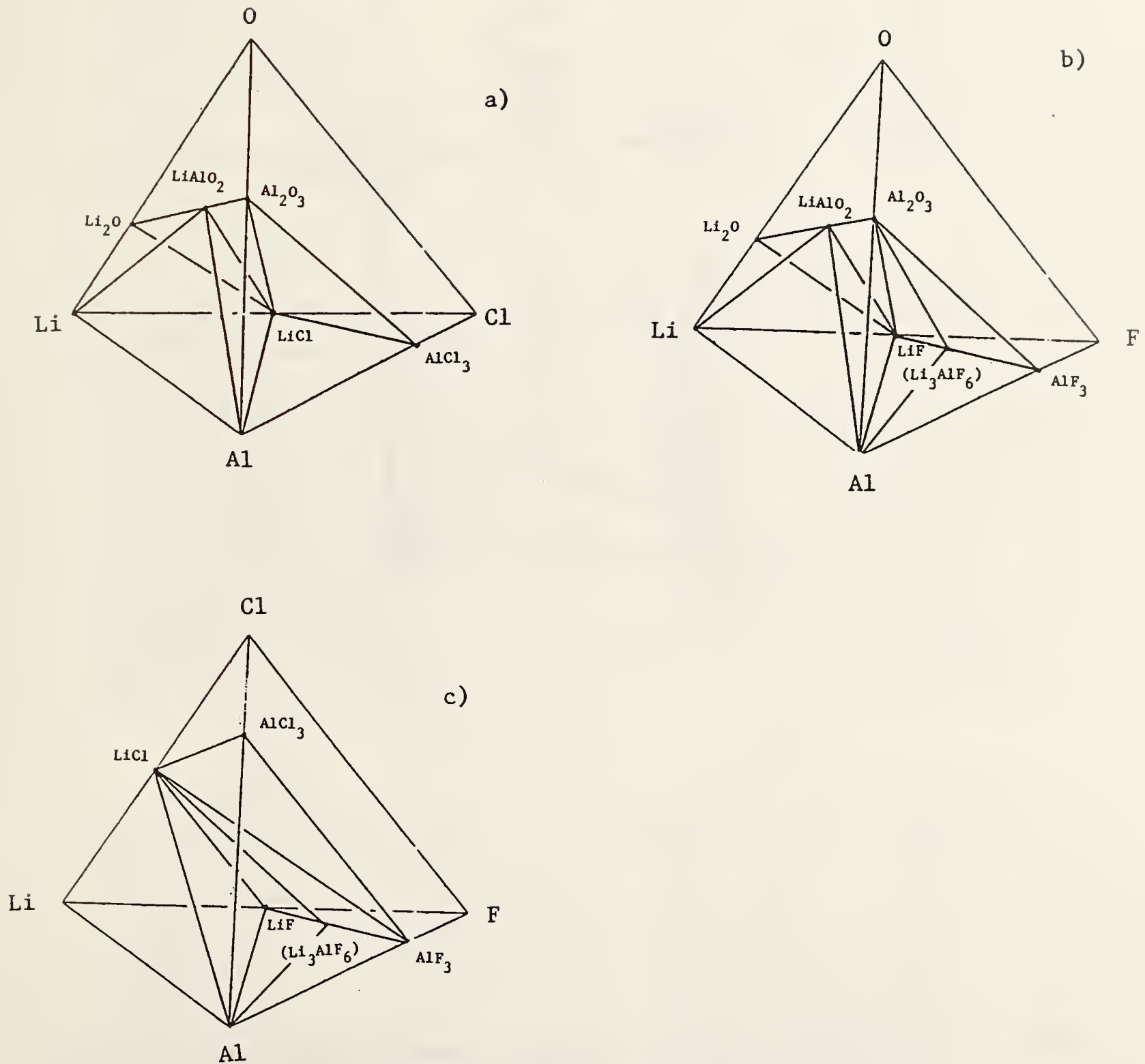
Figure 7. Outline of $1100 \mathrm{~K}, 1 \mathrm{~atm}$ phase compatibilities relating to
oxidation of LiAl alloy by $\mathrm{C}_{10} \mathrm{~F}$. (a) chlorination and oxy-
genation; (b) fluorination and oxygenation; (c) fluorination
and chlorination. 


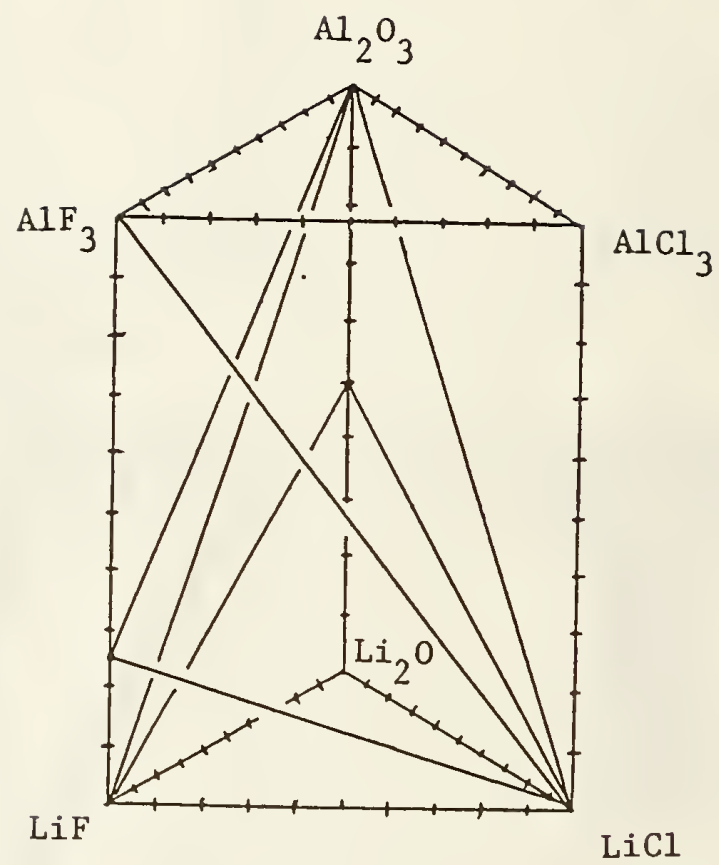

Figure 8. Outline of $1100 \mathrm{~K}, 1$ atm phase compatibilities among products of complete oxidation of LiAl alloy by $\mathrm{ClO}_{3} \mathrm{~F}$. 

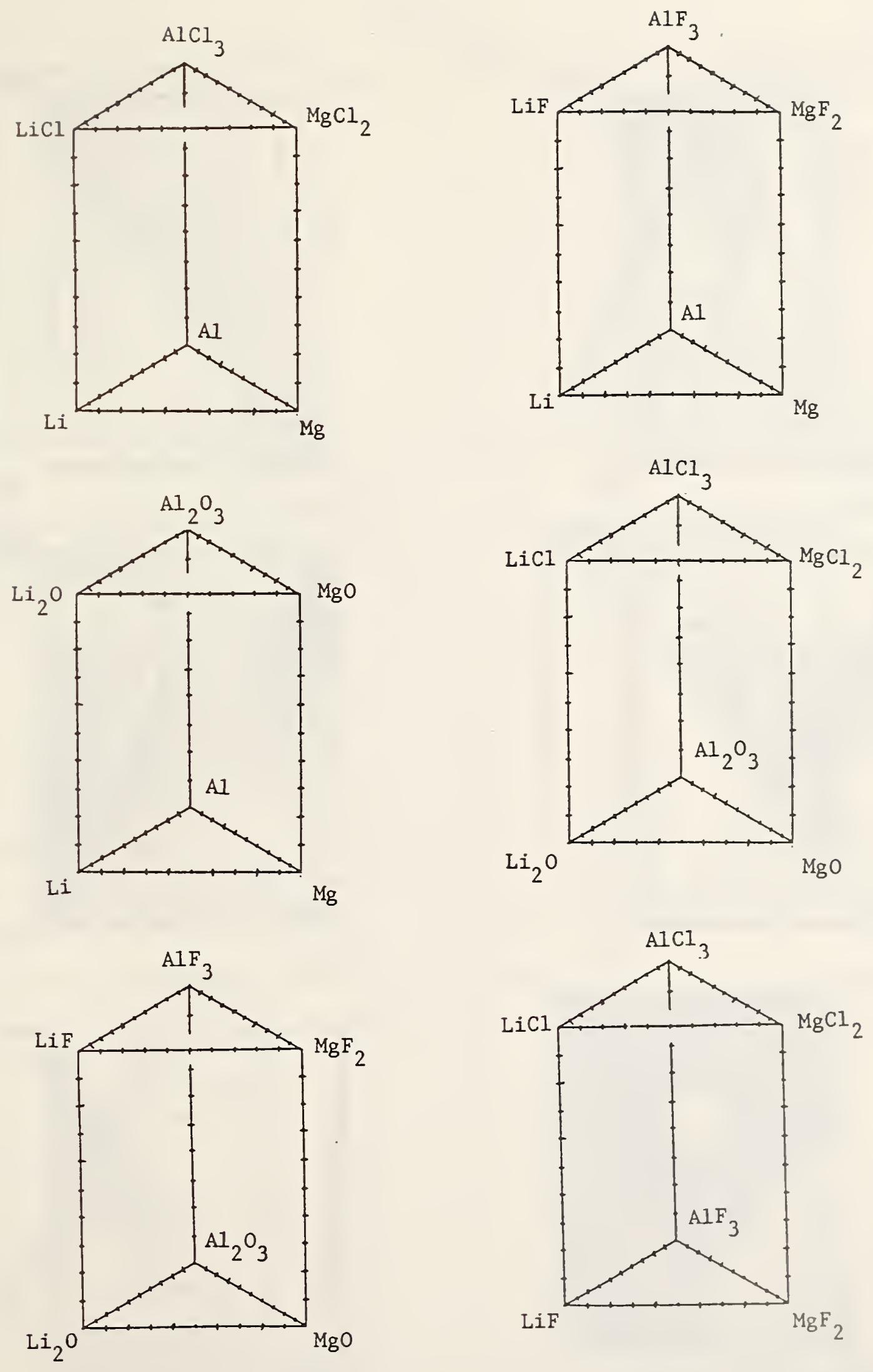

Figure 9. Quaternary reciprocal systems relevant to oxidation of LiAlMg alloy by $\mathrm{ClO}_{3} \mathrm{~F}$. 

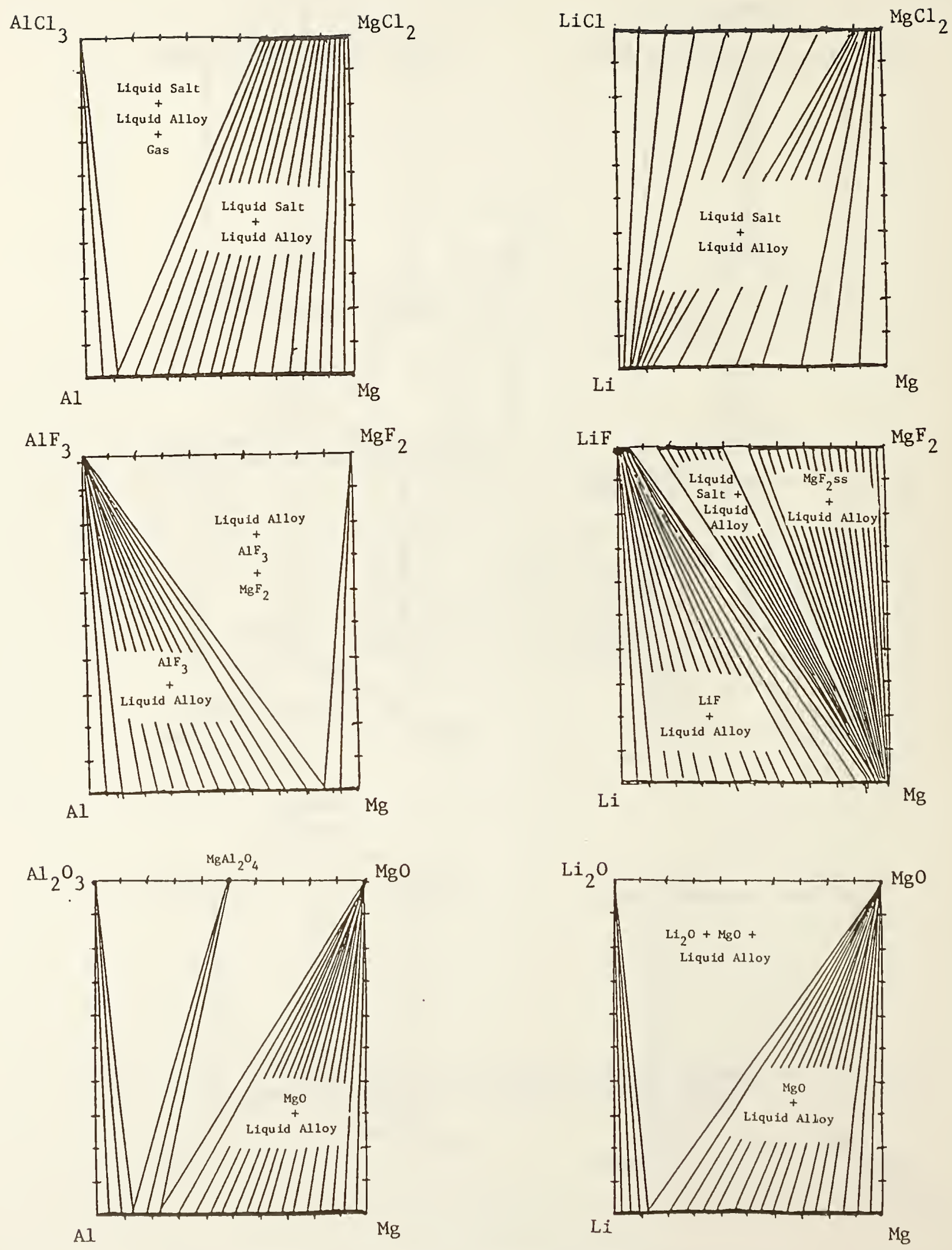

Figure 10. Calculated phase compatibilities in ternary reciprocal subsystems of the system $\mathrm{Li}-\mathrm{Al}-\mathrm{Mg}-\mathrm{Cl}-\mathrm{O}-\mathrm{F}$ at $1100 \mathrm{~K}, 1 \mathrm{~atm}$. 

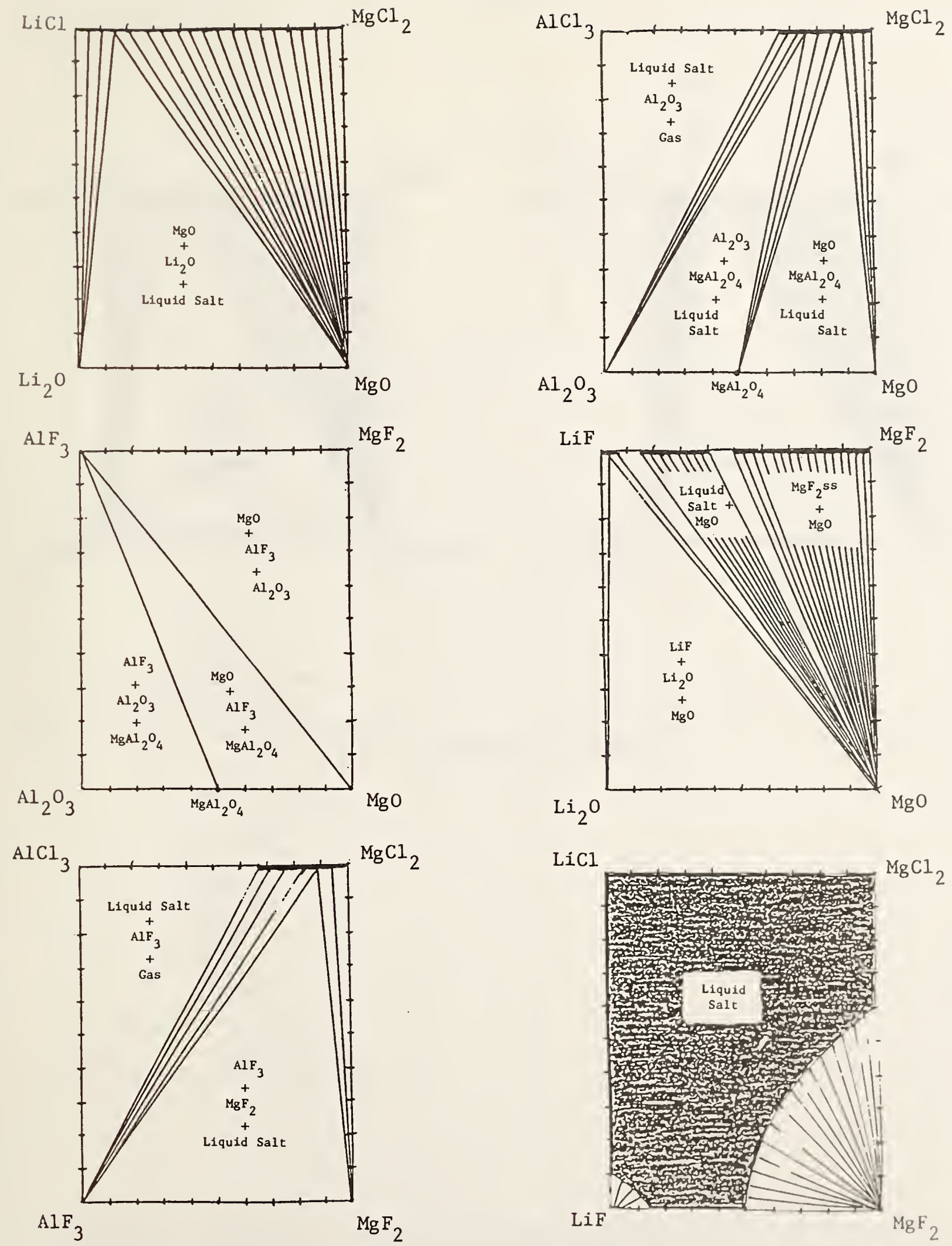

Figure 10, continued. 

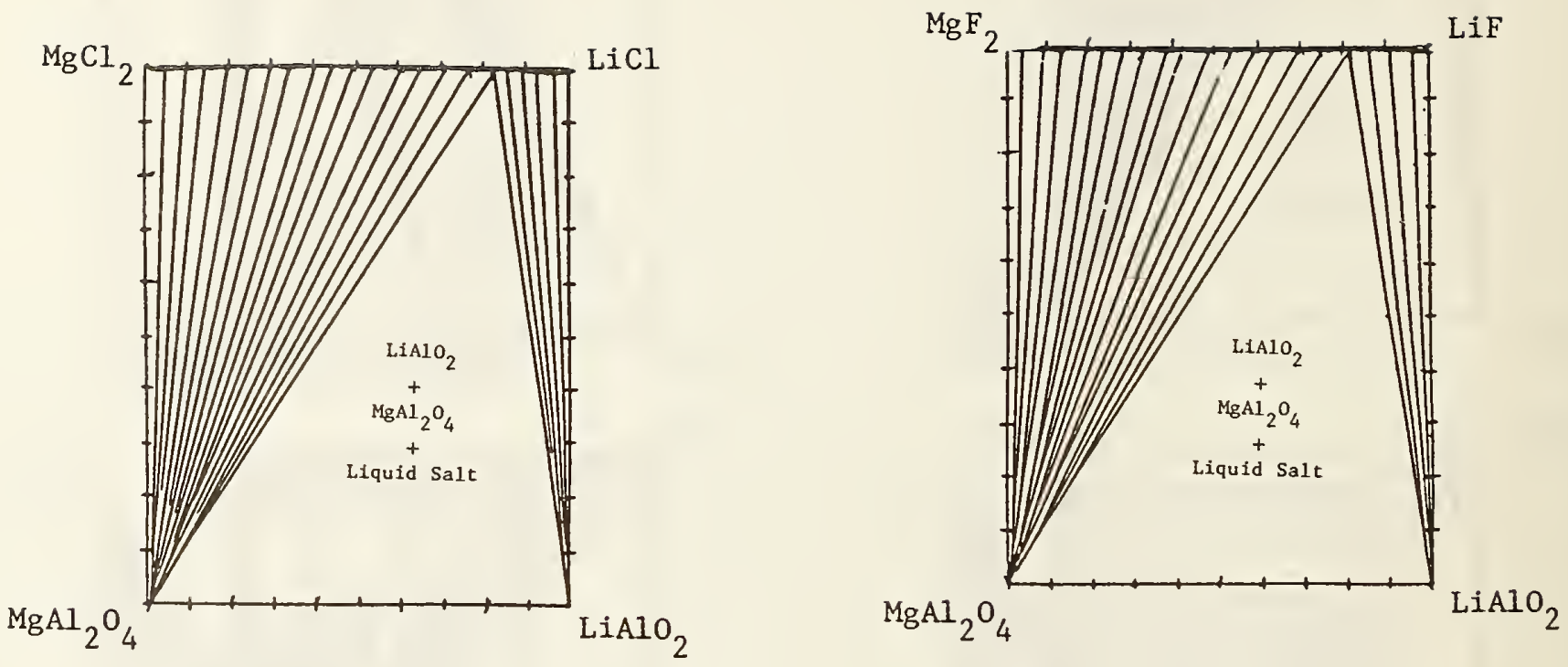

Figure 10, continued. 

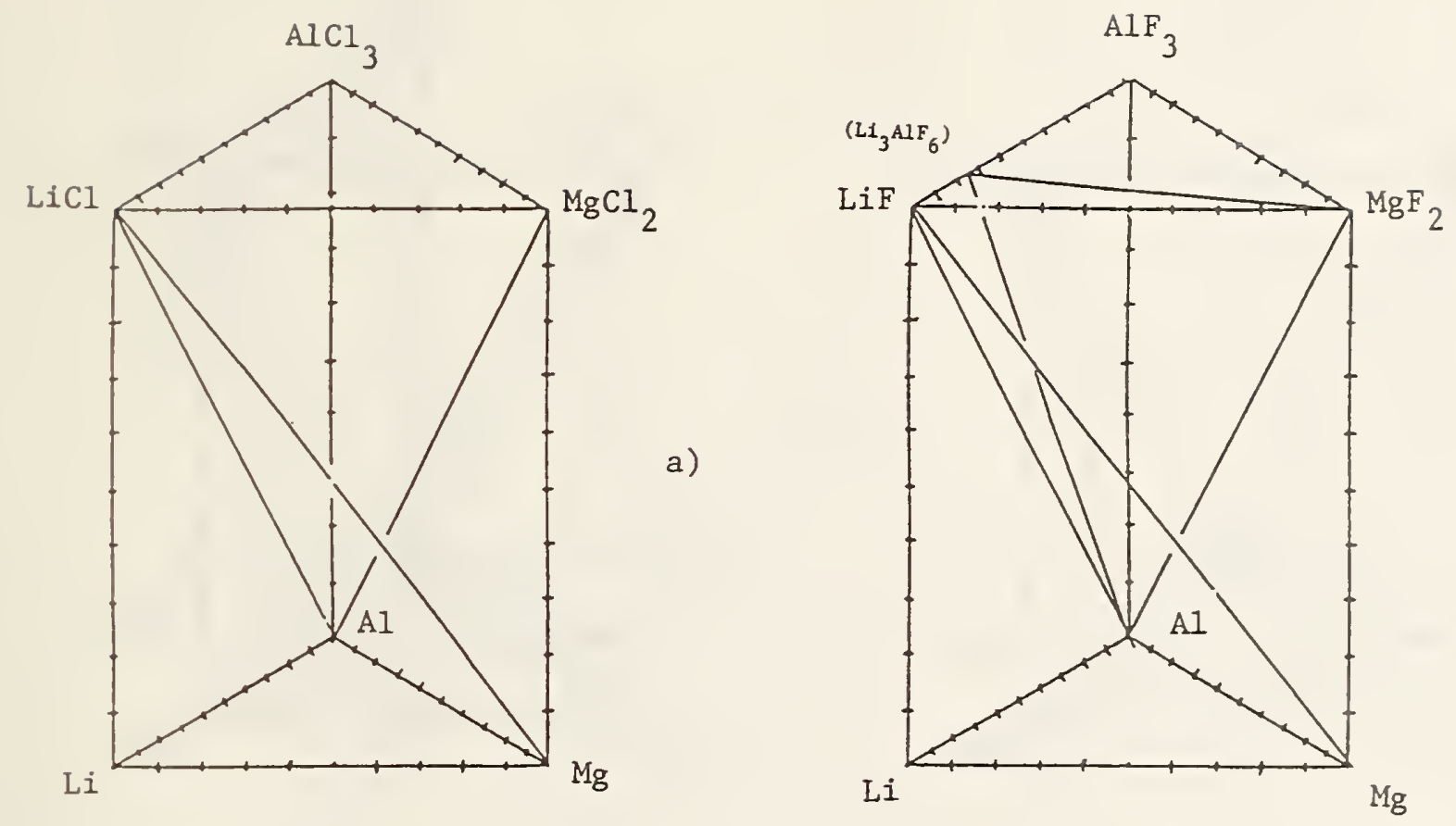

b)

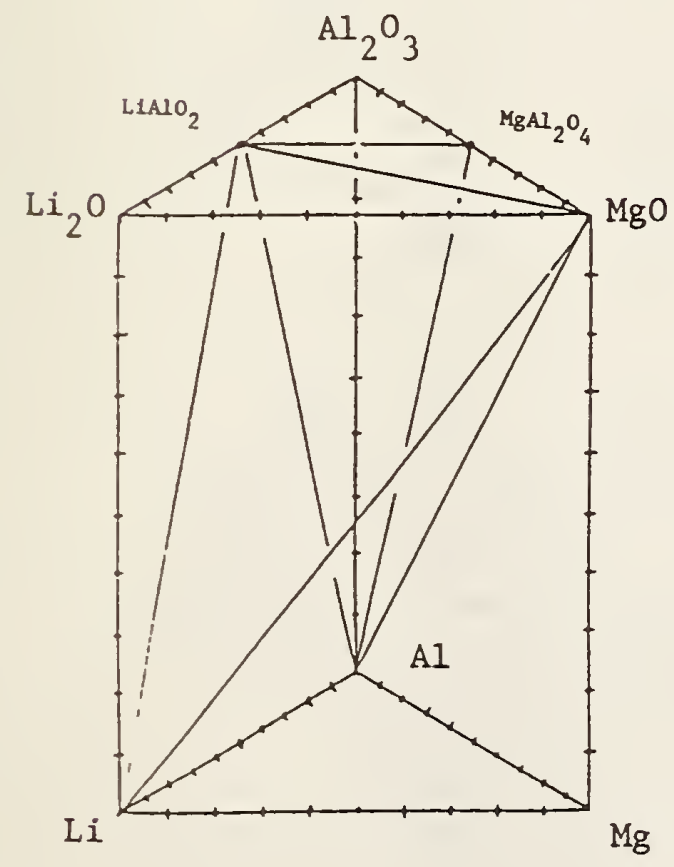

c)

Figure 11. Outline of $1100 \mathrm{~K}, 1$ atm phase compatibilities relating to oxidation of LiAlMg alloy by $\mathrm{ClO}_{3} \mathrm{~F}$. (a) chlorination;

(b) fluorination; (c) oxygenation. 

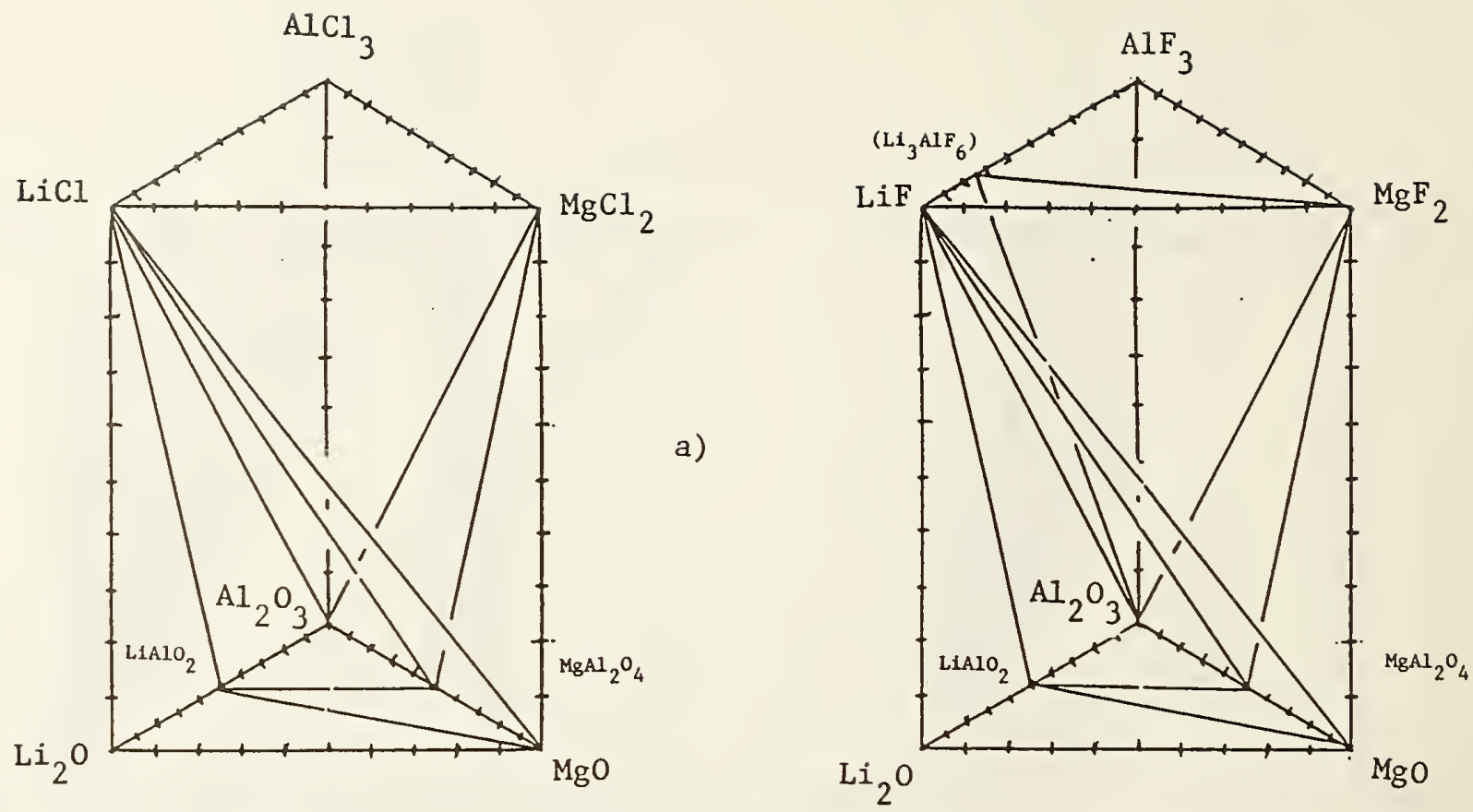

b)

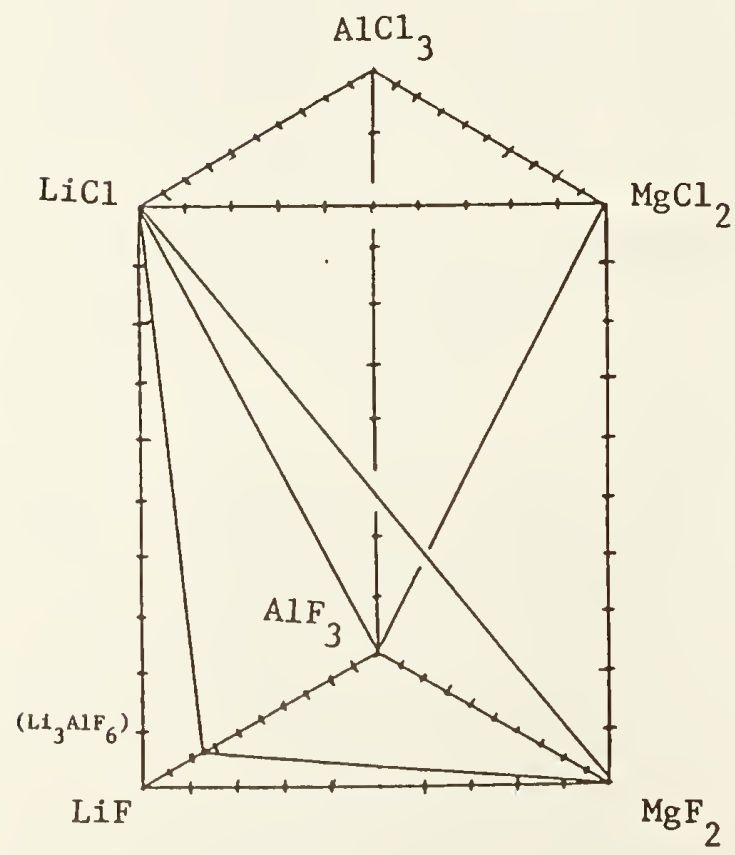

c)

Figure 12. Outline of $1100 \mathrm{~K}, 1$ atm phase compatibilities among products of complete oxidation of LiAlMg alloy by $\mathrm{ClO}_{3} \mathrm{~F}$. (a) chlorination and oxygenation; (b) fluorination and oxygenation;

(c) fluorination and chlorination 

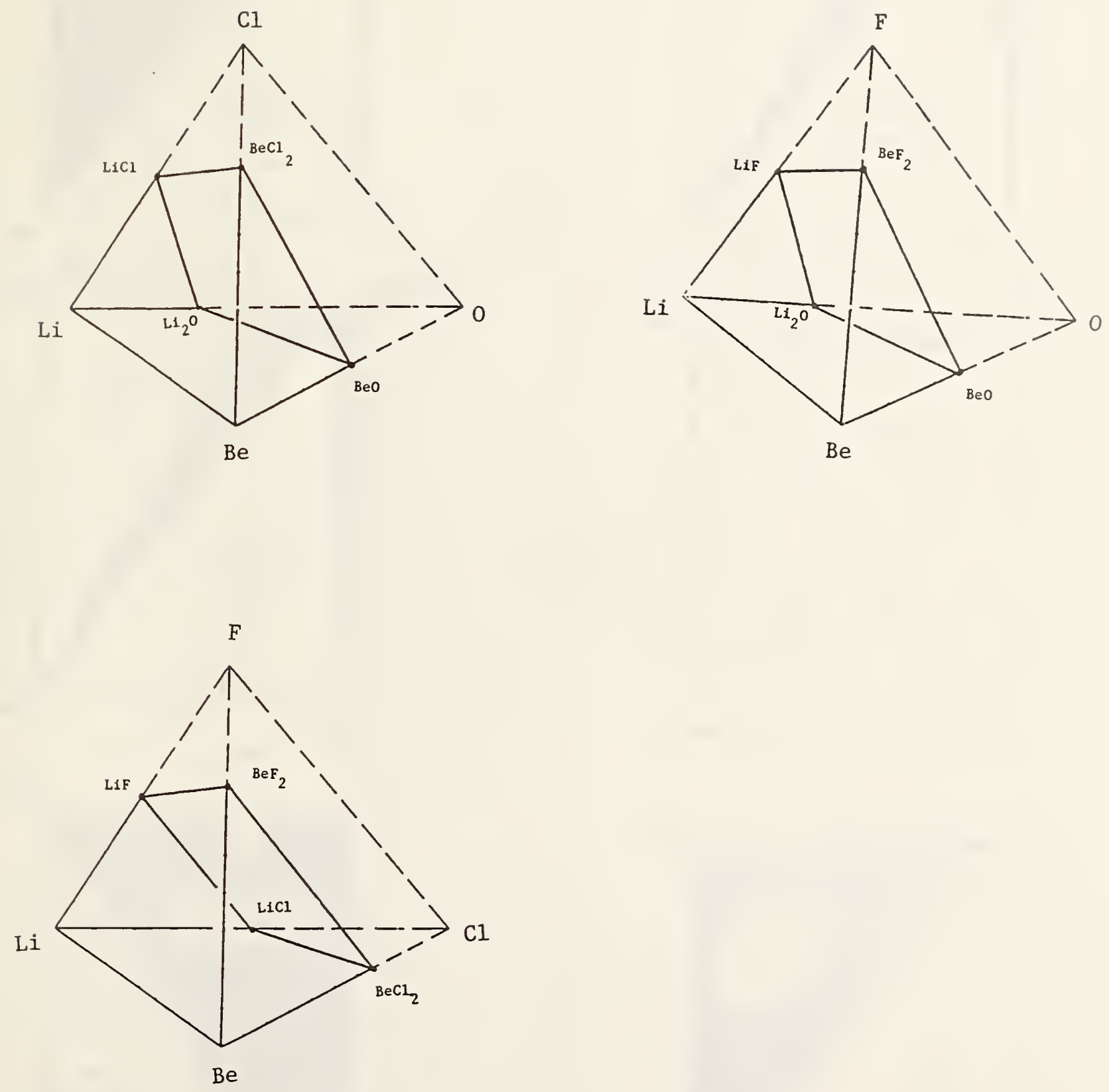

Figure 13. Quaternary reciprocal systems relevant to oxidation of Li/Be mixtures by $\mathrm{ClO}_{3} \mathrm{~F}$. 
LiCl

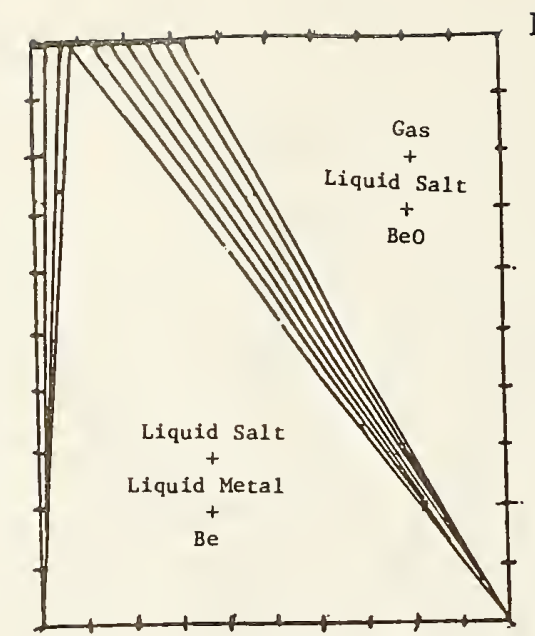

Li

$\mathrm{Li}_{2} \mathrm{O}$

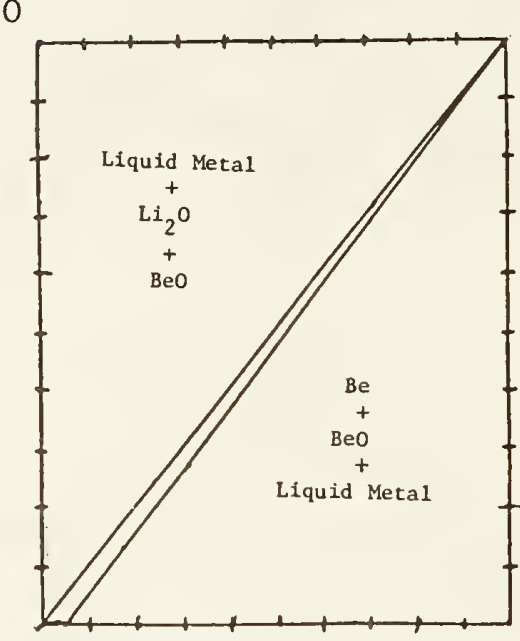

$\mathrm{Li}$

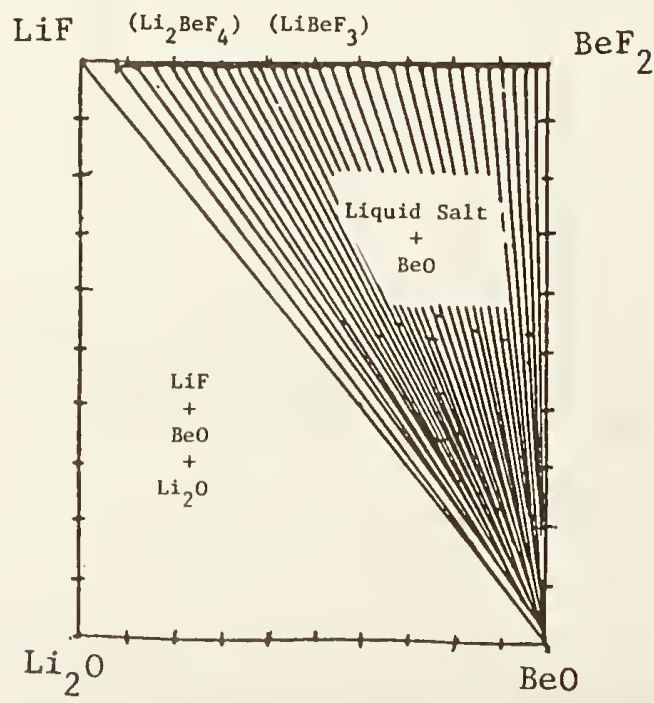

$\mathrm{BeCl}_{2}$

$\mathrm{Be}$

BeO

$\mathrm{Be}$

$\mathrm{eF}_{2}$

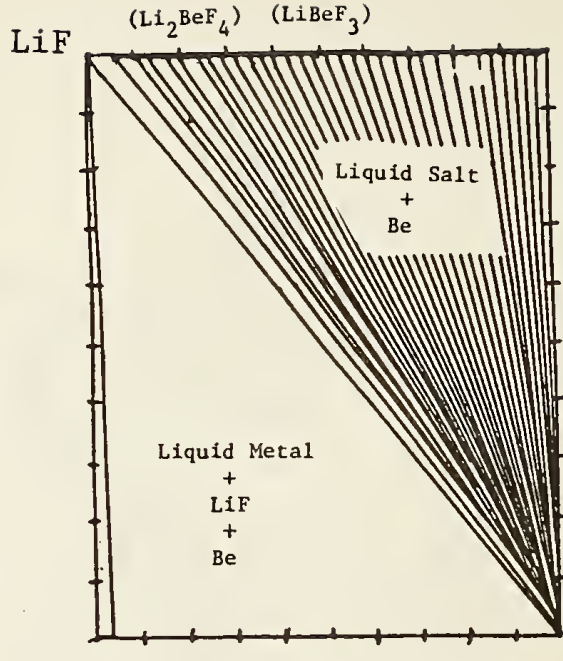

$\mathrm{BeF}_{2}$

Li

Be

LiCl

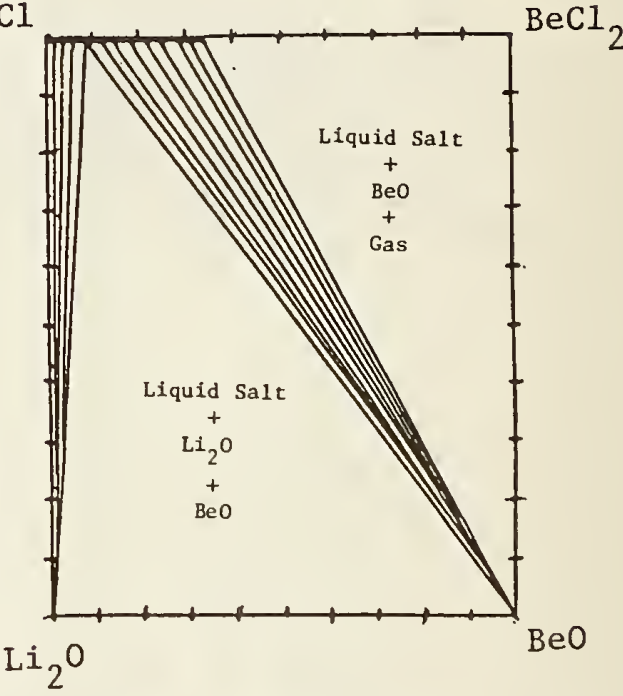

LiF

$\mathrm{BeF}_{2}$

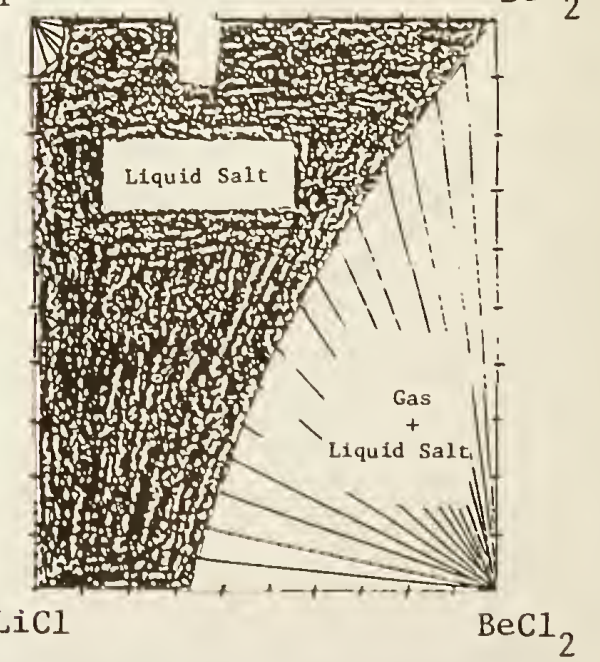

Figure 14. Calculated phase compatibilities in ternary reciprocal subsystems of the system $\mathrm{Li}-\mathrm{Be}-\mathrm{C} 1-\mathrm{O}-\mathrm{F}$ at $1100 \mathrm{~K}, 1 \mathrm{~atm}$. 


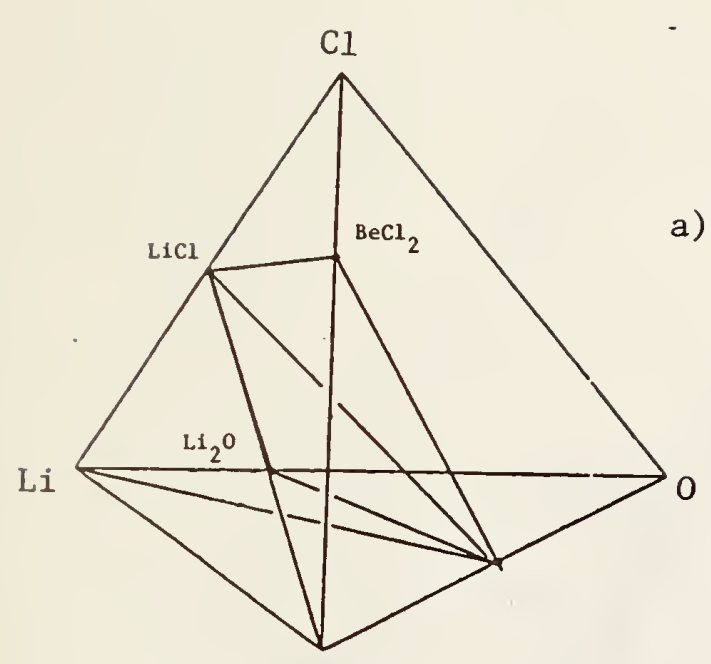

$\mathrm{Be}$
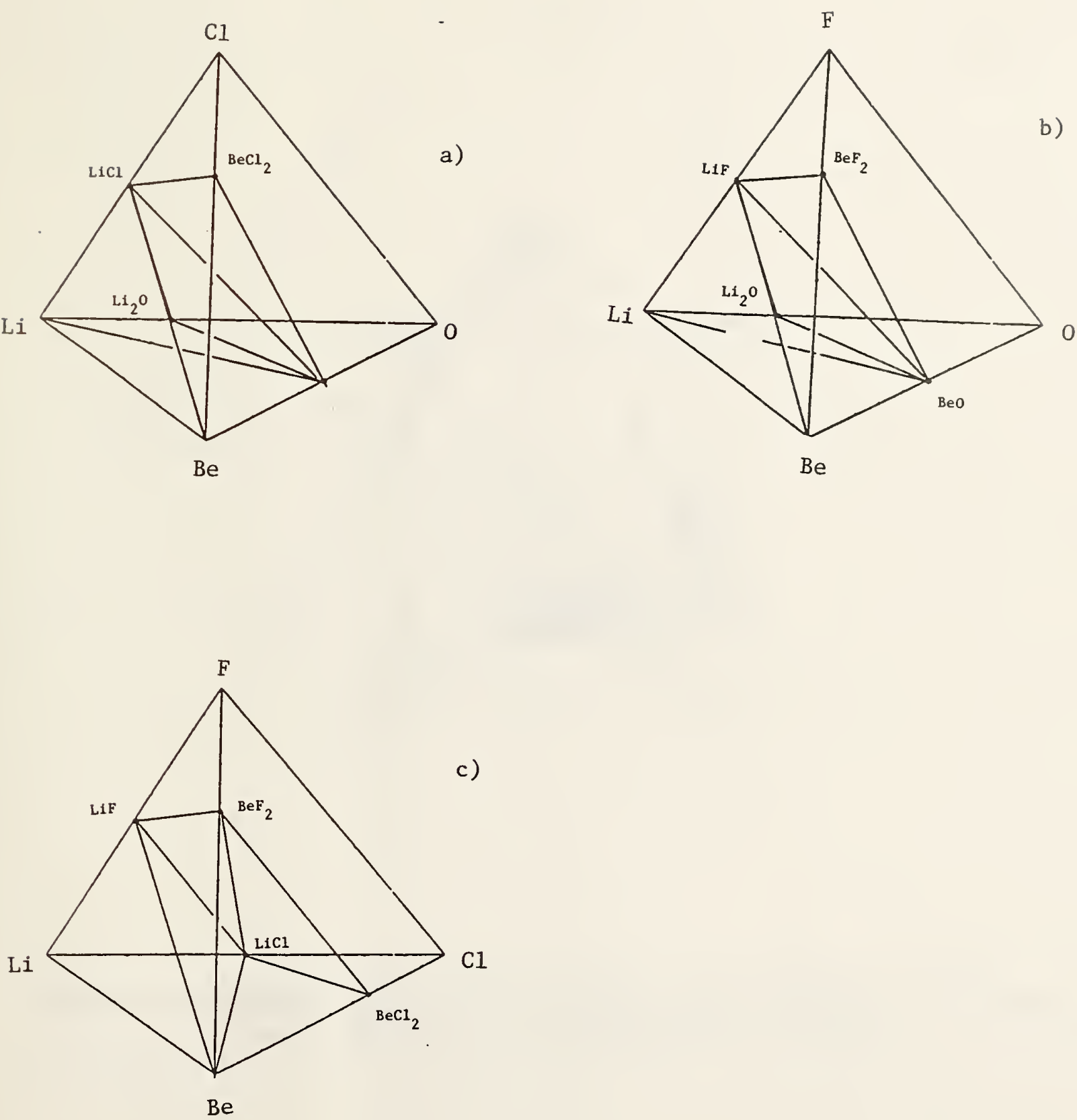

Figure 15. Outline of $1100 \mathrm{~K}, 1$ atm phase compatibilities relating to oxidation of Li/Be mixtures by $\mathrm{ClO}_{3} \mathrm{~F}$. (a) chlorination and oxygenation; (b) fluorination and oxygenation; (c) fluorination and chlorination. 


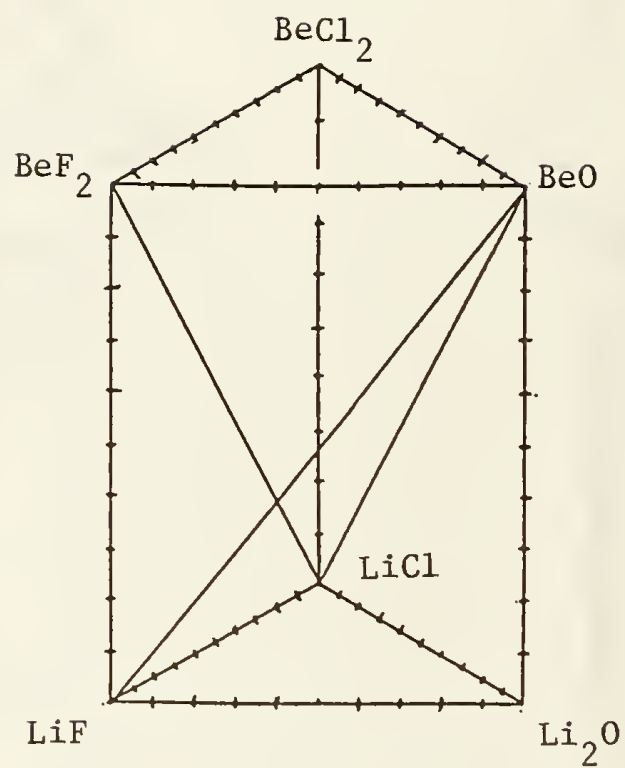

Figure 16. Outline of phase compatibilities anong products of complete oxidation of $\mathrm{Li} / \mathrm{Be}$ by $\mathrm{ClO}_{3} \mathrm{~F}$ at $1100 \mathrm{~K}, 1 \mathrm{~atm}$. 


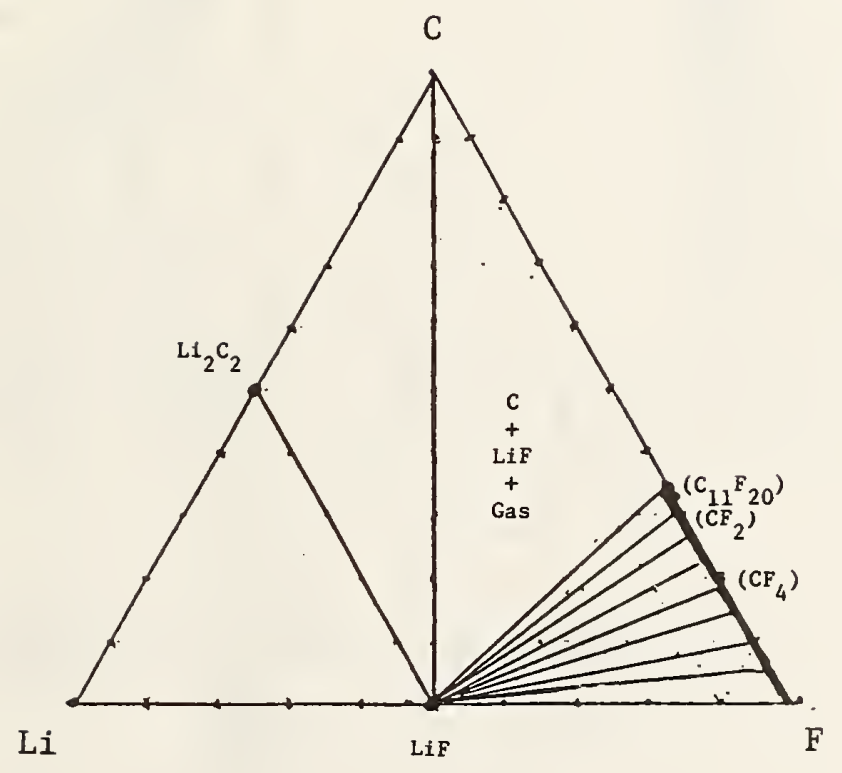

Figure 17. Calculated phase compatibilities in the system Li-C-F at $1100 \mathrm{~K}, 1 \mathrm{~atm}$. 


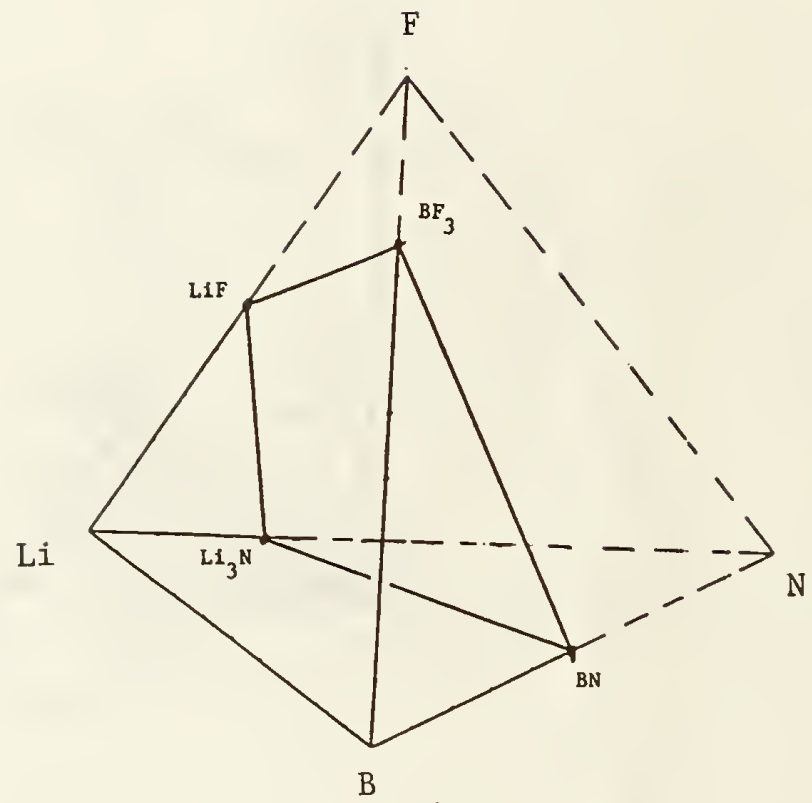

Figure 18. Quaternary reciprocal systems relevant to oxidation of LiB alloy by $\mathrm{NF}_{3}$. 

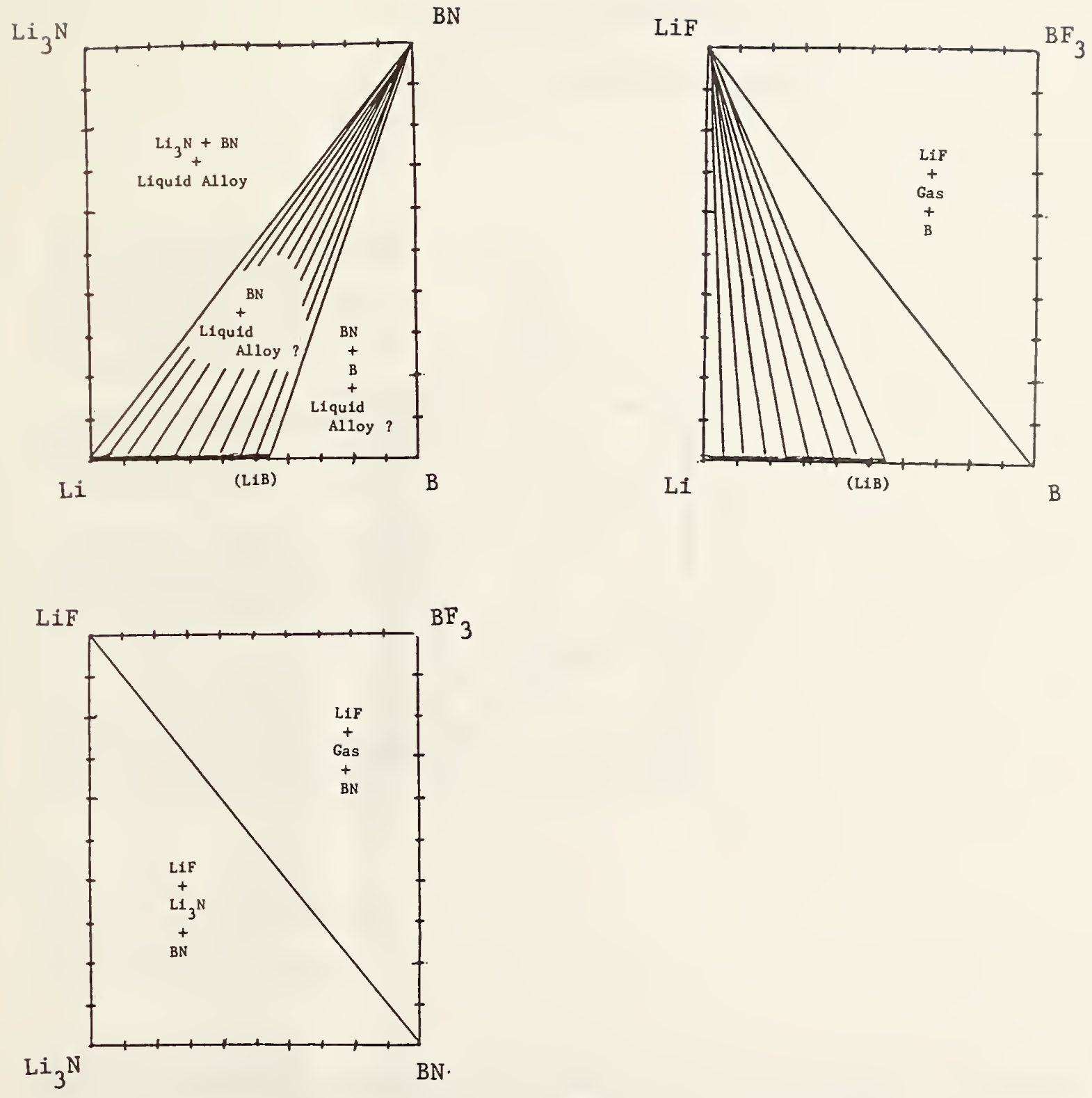

Figure 19. Calculated phase compatibilities in ternary reciprocal subsystems of the system $\mathrm{Li}-\mathrm{B}-\mathrm{F}-\mathrm{N}$ at $1100 \mathrm{~K}$, $1 \mathrm{~atm}$. 


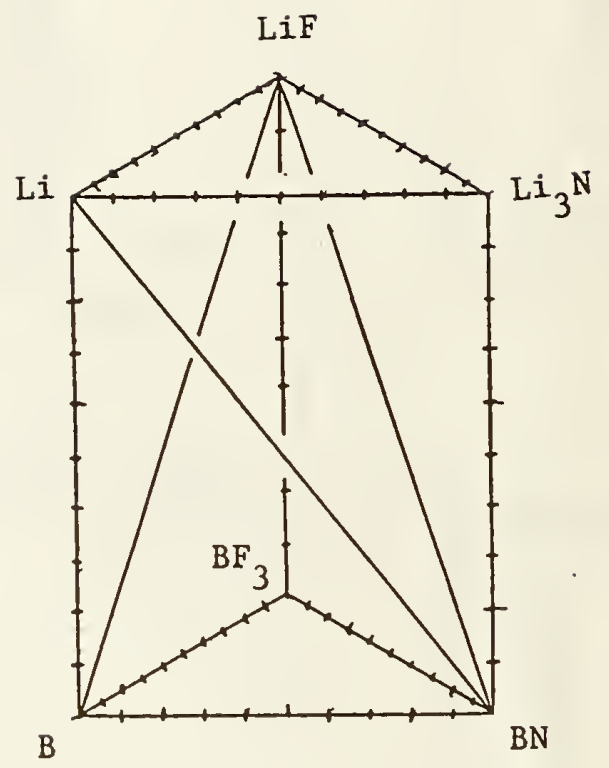

Figure 20. Outline of phase, compatibilities anong products of complete oxidation of $\mathrm{LiB}$ by $\mathrm{NF}_{3}$ at $1100 \mathrm{~K}, 1 \mathrm{~atm}$. 
ONR REPORT DISTRIBUTION LIST

CLOSED, LIQUID METAL COMBUSTION

One copy except as noted

Mr. M. Keith Ellingsworth

Mechanics Division

Office of Naval Research

800 N. Quincy Street

Arlington, VA. 22217

Defense Documentation Center

Building 5, Cameron Station

Alexandria, VA. 22314

Technical Information Division

Naval Research Laboratory

4555 Overlook Avenue SW

Washington, DC 20375

Or. Jerry A. Smith

Chemistry Division

Office of Naval Research

800 N. Quincy Street

Arlington, VA. 22217

Or. Albert D. Wood

Technology Programs

Office of Naval Research

800 N. Quincy St.

Arlington, VA. 22217

Dr. H.W. Carhart

Combustion \& Fuels

Naval Research Laboratory

Washington, DC 20375

Professor Allen Fuhs

Department of Aeronautics

Naval Post Graduate School

Monterey, California 93943

Division Director

Engineering and Weapons

US Naval Academy

Annapolis, Maryland 21402

$\mathrm{Mr}$. Francis J. Romano

Code 63R3

Naval Sea Systems Command

Washington, DC 20363 
Mr. Robert Tompkins

Code 36621, Bldg 126T

Naval Underwater Systems Center

Newport, Rhode Island 02841

Mr. Maurice F. Murphy

Code R33, Room 4-1711

Naval Surface Weapons, White Oak

Silver Spring, Maryland 20910

Dr. Kurt Mueller

Code R10

Energetic Materials Division

Naval Surface Weapons Center, White Oak

Silver Spring, Maryland 20910

Or. Lynn A. Parnell

Code 6341

Naval Ocean Systems Center

San Diego, California 92152

Dr. Earl Quandt, Jr.

Code 2704

David Taylor Naval Ship

Research and Development Center

Annapolis, MD 21402

$\mathrm{Mr}$. Richard Bloomquist

Code 2752

David Taylor Naval Ship R\&D Center

Annapolis, Maryland 21402

Dr. Lawrence P. Cook

High Temperature Processes Group

National Bureau of Standards

Washington, DC 20234 
OL/432/84/316

One copy except as noted

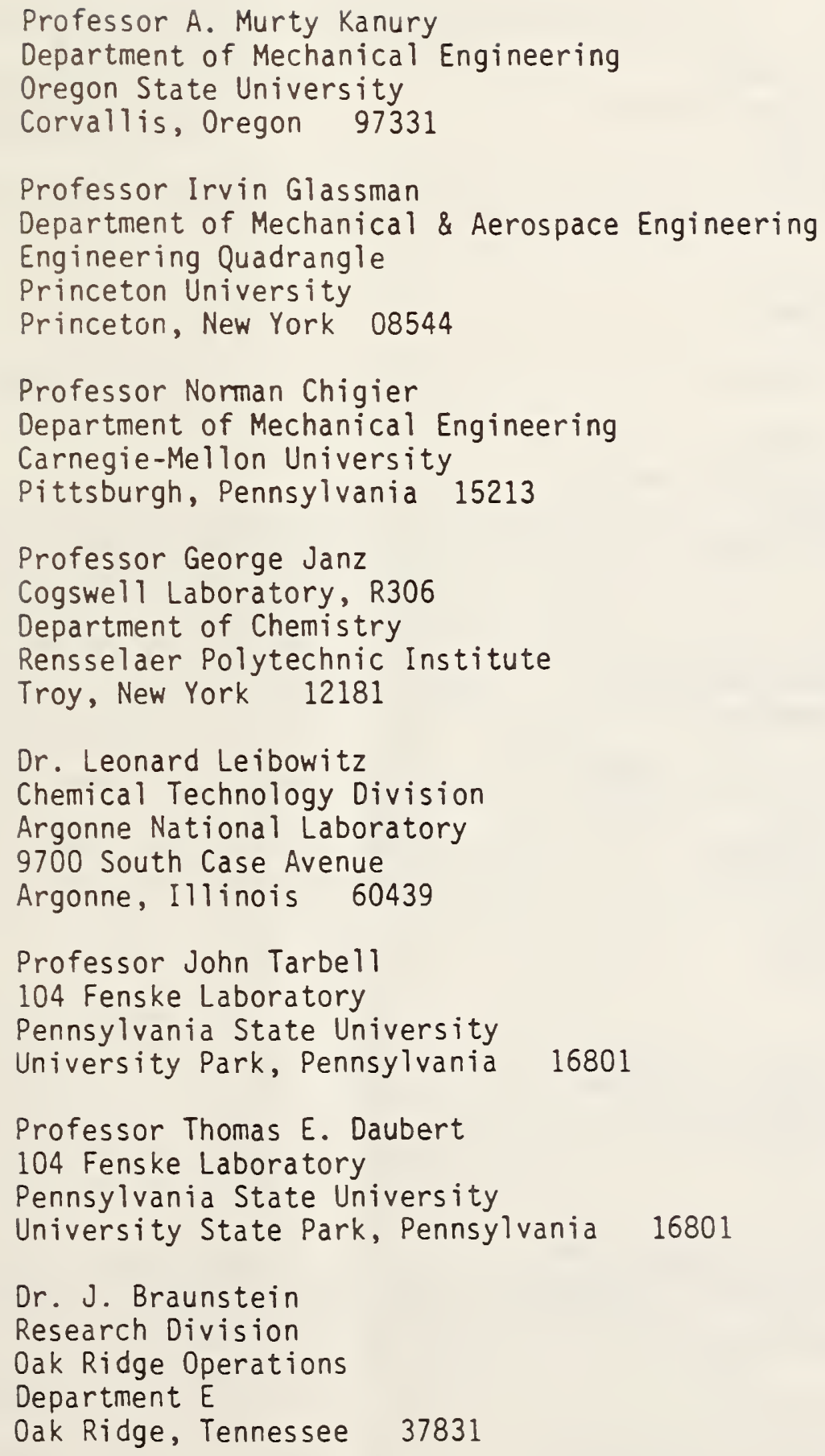




\author{
Mr. Norman D. Hubele \\ Fluidic Systems, MS 1301-RR \\ Garrett Pneumatic Systems Division \\ 2801 East Washington St. \\ Phoenix, Arizona 85034 \\ Dr. Hugh H. Darsie \\ Advanced Technology Group \\ Sunstrand Energy Systems \\ 4747 Harrison Avenue \\ Rockford, Illinois 61101 \\ Professor Gerard M. Faeth \\ Department of Aerospace Engineering \\ University of Michigan \\ Ann Arbor, Michigan 48109 \\ Dr. Dan H. Kiely \\ Power \& Energy Group \\ The Pennsylvania State University \\ Applied Research Laboratory \\ P.0. Box 30 \\ State College, Pennsylvania 16801 \\ Professor Darryl E. Metzger \\ Department of Mechanical \& \\ Aerospace Engineering \\ Arizona State University \\ Tempe, Arizona 85281 \\ Dr. Dae H. Cho \\ Reactor Analysis \& Safety Division \\ Argonne National Laboratory \\ Argonne, Illinois 60439 \\ Professor S.H. Chan \\ Department of Mechanical Engineering \\ The University of Wisconsin-Milwaukee \\ P.0. Box 784 \\ Milwaukee, Wisconsin 53201 \\ Professor George A. Brown \\ Department of Mechanical Engineering \\ and Applied Mechanics \\ University of Rhode Island \\ Kingston, Rhode Is I and 02881
}




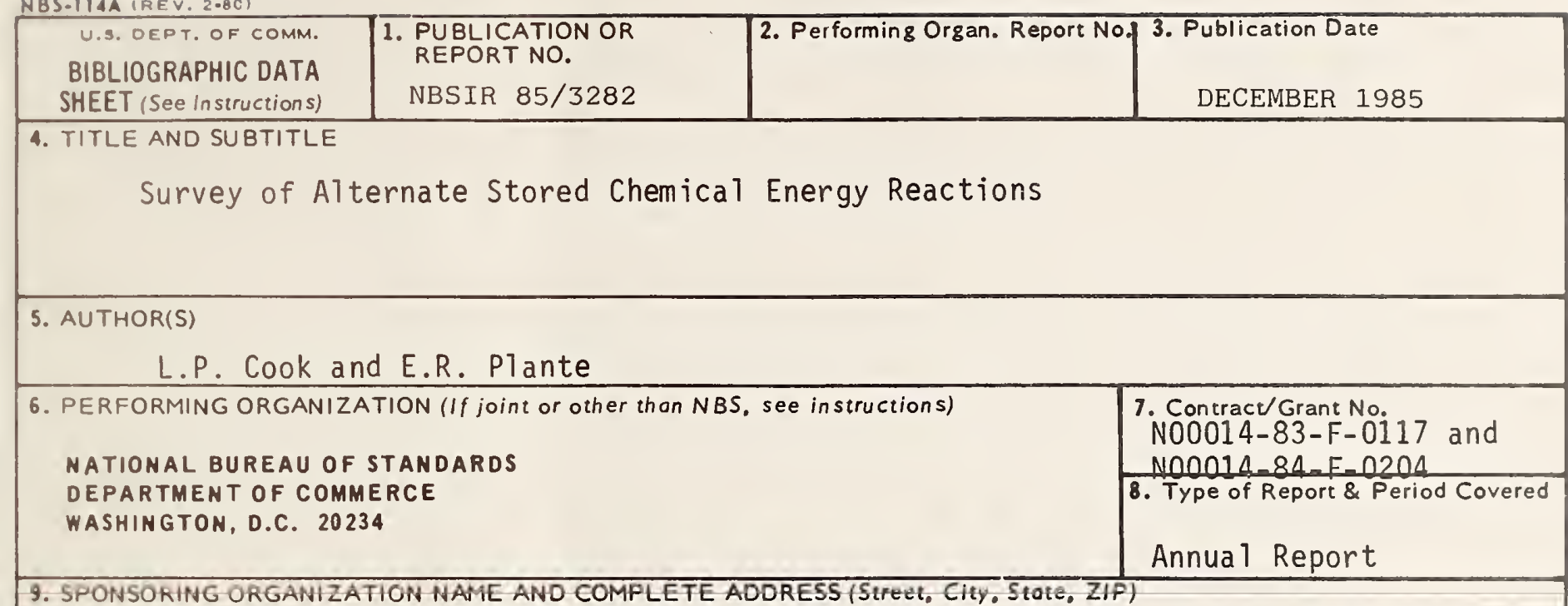

9. SPONSORING ORGANIZATION NANE AND COMPLETE ADORESS (StreUt, CIty, StOTE, ZIF)

REPORT NO.

NBSIR $85 / 3282$

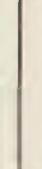

10. SUPPLEMENTARY NOTES

Document describes a computer program; SF-185, FIPS Software Summary, is attached.

11. ABSTRACT (A 200-word or less foctual summary of most significant information. If document includes o significant bibliography or literature survey, mention it here)

A survey of eight alternative liquid metal stored chemical energy reactions has been made for purposes of comparison with the 1 ithium-aluminum/water, 1 ithium/sulfur hexafluoride, and other reaction schemes. The objective of the study was to survey the potential of these eight reactions as alternate stored chemical energy systems and to develop priorities for future study. Experimental data on the products of reaction and kinetics of reaction are presented for: $\left(\mathrm{Li} / \mathrm{H}_{2} \mathrm{O} ; \mathrm{H}_{2} / \mathrm{O}_{2}\right),\left(\mathrm{Li} / \mathrm{H}_{2} \mathrm{O} ; \mathrm{NaO} \mathrm{N}_{2} / \mathrm{H}_{2} \mathrm{O} ; \mathrm{H}_{2} / \mathrm{O}_{2}\right)$, $\left(\mathrm{MgAT} / \mathrm{H}_{2} \mathrm{O} ; \mathrm{H}_{2} / \mathrm{O}_{2}\right)$, and $\left(\mathrm{LiAl} / \mathrm{ClO}_{3} \mathrm{~F}\right)$. These data have been col Tected using thermogravimetry and Knudsen effusion mass spectrometry, with $x$-ray diffraction analys is of experimental products. Among other results, the data show that the aluminum component of the fuels is relatively inert to oxidation up to $650^{\circ} \mathrm{C}$. Above this temperature, materials limitations have hampered the collection of experimental data.

Thermodynamic analysis has been used to extend the data on each of the eight reaction schemes, and to predict the chemical reaction with best represents the complete oxidation of each fuel by the indicated oxidant at $1100 \mathrm{~K}$. Enthalpies have been calculated for each fuel/oxidant combination. Safety considerations are also discussed for each. Suggestions for future research are given, including suggestions for overcoming the materials problems encountered in this study.

12. KEY WORDS (Six to twelve entries; olphabetical order: capitolize only proper names; and separate key words by semicolons) enthalpy yield, kinetics, liquid metal combustion, lithium, lithium-aluminum

lithium -boron, 1ithium-beryllium, magnesium-alumium, nitrogen trifluoride, water

13. AVAILABILITY

X Unlimited

$\square$ For Official Distribution. Do Not Release to NTIS

$\square$ Order From Superintendent of Documents, U.S. Government Printing Office, Washington, D.C. 20402.

14. NO. OF

PRINTED PAGES

109

15. Price

区] Order From National Technical Information Service (NTIS), Springfield, VA. 22161 


